\title{
LSE
}

LSE 'Europe in Question' Discussion Paper Series

\section{Lending Cycles and Real Outcomes: Costs of Political Misalignment}

Çağatay Bircan \& Orkun Saka

LEQS Paper No. 139/2018 December 2018

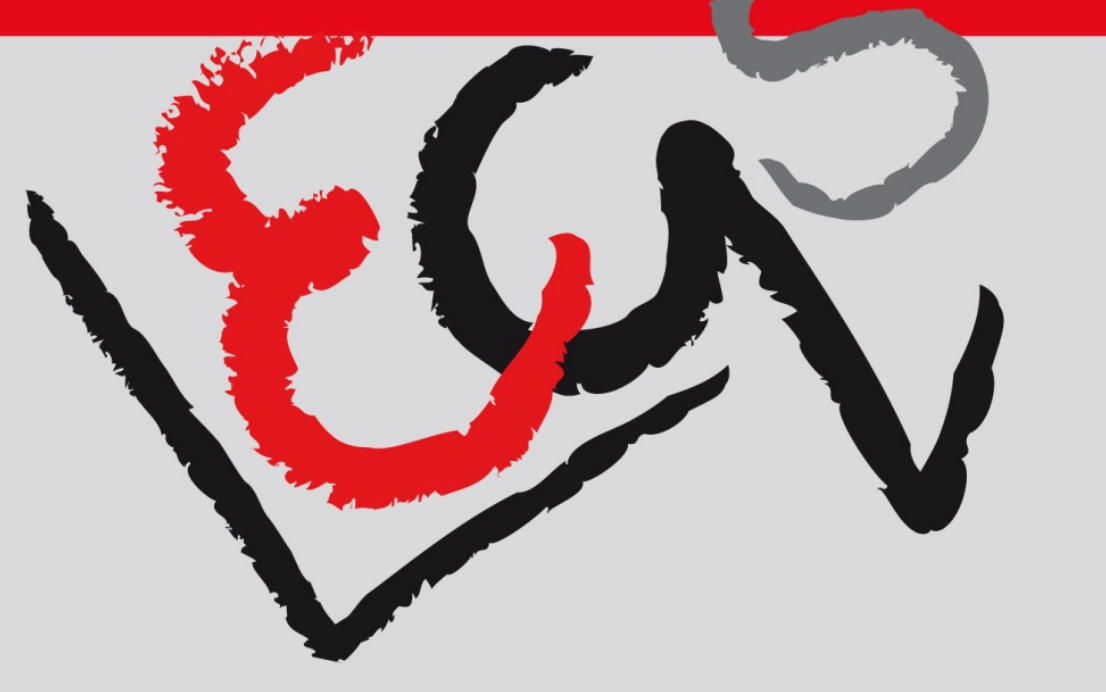




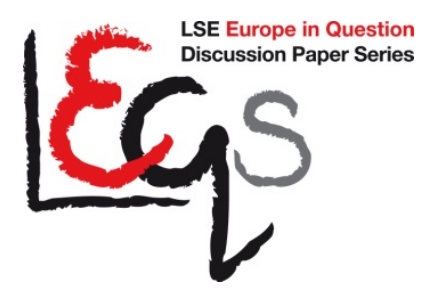

\author{
Editorial Board \\ Dr Bob Hancké \\ Dr Jonathan White \\ Dr Sonja Avlijas \\ Mr Sean Deel
}

All views expressed in this paper are those of the authors and do not necessarily represent the views of the editors, the LSE, or the European Bank for Reconstruction and Development (EBRD).

(c) Çağatay Bircan \& Orkun Saka

Eqs 


\title{
Lending Cycles and Real Outcomes: Costs of Political Misalignment
}

\author{
Çağatay Bircan* \& Orkun Saka**
}

\begin{abstract}
We document a strong political cycle in bank credit and industry outcomes in Turkey. In line with theories of tactical redistribution, state-owned banks systematically adjust their lending around local elections compared with private banks in the same province based on electoral competition and political alignment of incumbent mayors. This effect only exists in corporate lending as opposed to consumer loans. It creates credit constraints for firms in opposition areas, which suffer drops in employment and sales but not firm entry. There is substantial misallocation of financial resources as provinces and industries with high initial efficiency suffer the greatest constraints.
\end{abstract}

Keywords: Bank credit; Electoral cycle; State-owned banks; Credit misallocation

JEL Codes: G21, D72, D73, P16

\footnotetext{
* European Bank for Reconstruction and Development

Email: bircanc@ebrd.com

** London School of Economics and Political Science

Email: o.saka@lse.ac.uk
} 


\section{Table of Contents}

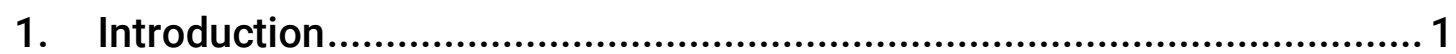

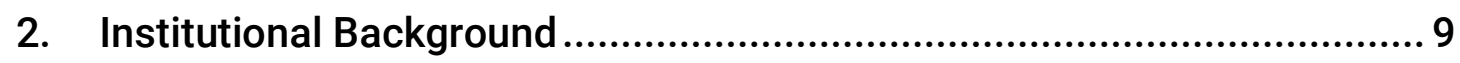

2.1 The Turkish Banking Sector ................................................................... 9

2.2 Politics and local elections in Turkey................................................ 12

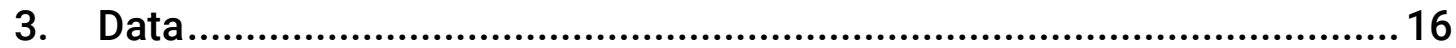

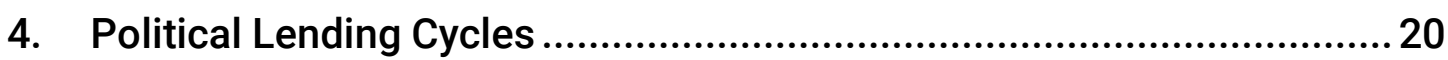

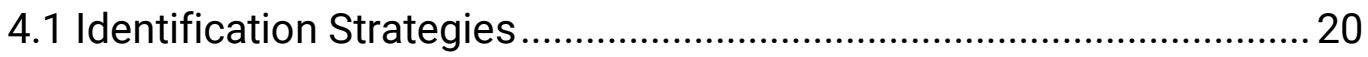

4.2 Is there an election cycle in state-bank credit? ................................... 22

4.3 Is there tactical redistribution across provinces? ................................. 25

4.4 Testing for the lending cycle in yearly data .......................................... 32

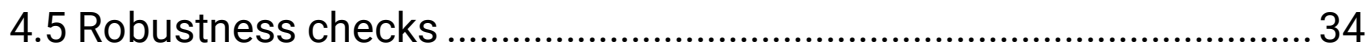

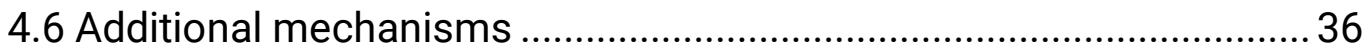

5. How does political lending affect economic outcomes?........................ 42

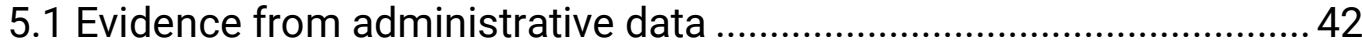

5.2 Evidence on efficiency \& misallocation ............................................... 46

5.3 Do jobs affect elections? ..................................................................... 48

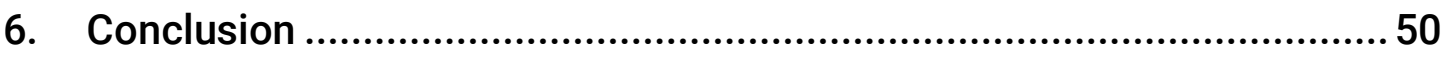

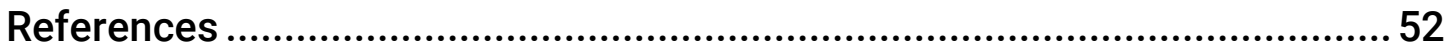

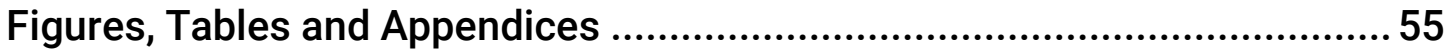

\section{Acknowledgments}

We are grateful to Thorsten Beck, Travers Child, Paul De Grauwe, Ralph De Haas, Serdar Dinç, Sergei Guriev, Davide Luca, lan Marsh, and our discussants Pat Akey, Thomas Lambert, and Laura Solanko for their comments and suggestions. We also thank seminar participants at Cass Business School, European Bank for Reconstruction and Development (EBRD), London School of Economics, Sabanci University, European Finance Association (Warsaw), Workshop in New Perspectives on Political Economy of the Middle East (University of Oxford), 11th Swiss Winter Conference on Financial Intermediation (Lenzerheide), Royal Economic Society 2018 Annual Conference, Workshop on Finance and Politics (University of Strasbourg), and German Economic Association 2018 Conference on Development Economics. Part of this research was completed while Orkun was visiting the EBRD, whose hospitality is gratefully acknowledged. Views expressed in this paper are those of the authors only.

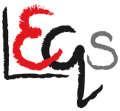




\section{Lending Cycles and Real Outcomes: Costs of Political Misalignment}

\section{Introduction}

What are the consequences of political influence on banking and economic outcomes? Theories of political lending cycles predict that governments use loans by state-owned banks as a strategic tool for re-election purposes. In particular, bank credit can be reallocated around election years with the aim of shifting local election outcomes in favour of the ruling party or coalition parties in control of central government. Does such targeted redistribution simply favour certain regions, or can it be used to punish others on the basis of their attractiveness to politicians? If so, does this reallocation have real effects on the local economy?

We test theories of political cycles in Turkey using the universe of bank credit and corporate balance sheet data for the country over the past fifteen years. We collect detailed information on election outcomes, banking activity, and indicators of economic activity observed at the local level. Unlike previous literature, we can draw on quarterly data to identify the exact timing of politically induced lending and shed light on potential mechanisms. Our data allow us to differentiate between the effects of politically driven lending on firms and 
consumers separately. We complement these data with information from corporate balance sheets aggregated at the industry-by-province level for the entirety of the Turkish firms in operation. This allows us to quantify the extent to which politically induced lending distorts economic outcomes and leads to misallocation of financial resources at the aggregate level.

We document two main sets of findings. First, we show that state-owned banks engage in strategic lending around local elections when compared with private banks. In contrast to earlier literature, state-owned banks curb aggregate credit prior to local elections and increase lending immediately afterward. However, this result is driven by cross-sectional reallocation of credit between constituencies defined by their political alignment and the degree of electoral competition. In particular, state bank lending increases in provinces when an incumbent mayor aligned with the ruling party in central government faces competition from opposition parties. In contrast, closely contested provinces get relatively less credit from state banks in the run up to elections if the incumbent mayor is from an opposition party. We interpret this vastly different behaviour of state banks around elections as strong evidence for the existence of a political lending cycle, consistent with incentives of "tying your enemy's hands in close races" (Brollo and Nannicini, 2012). It appears that the central government - via its control over state banks - strategically targets provinces either to support their own mayors, or to punish opposition mayors, so that their candidates have a better chance in upcoming elections.

Election cycles and close election outcomes provide a quasi-exogenous variation in how aggregate credit is reallocated across the country. We expect this reallocation to have real consequences if borrowers are unable to switch lenders, meaning that politically induced lending might alleviate credit constraints in 
aligned provinces and exacerbate them in non- aligned provinces. ${ }^{1}$ In our second set of findings, we present evidence that local economic activity is strongly influenced by this reallocation. Economic activity suffers in provinces with an opposition mayor and close electoral competition in industries in which state banks have a larger share of the credit market nationally. We draw on administrative data collected from balance sheets and income statements of every formally registered firm in Turkey and aggregated to the industry and province level to document these effects. In particular, we show that industries with a high share of state bank lending located in politically contested provinces experience substantial reductions in employment, sales, and assets in the run up to local elections if the incumbent mayor is from an opposition party. We find the exact opposite patterns for provinces if the incumbent mayor is from the ruling party, although these estimates are not statistically significant.

In line with the interpretation that this reallocation of economic activity is driven by the political lending cycle, we find that credit extended to the corporate sector follows the same pattern. Businesses in politically non-aligned provinces appear unable to switch lenders around local elections and suffer financial constraints, especially in their access to longer term credit. In contrast, businesses in provinces that are aligned with the ruling party have easier access to credit. We further document that credit growth in the run up to a local election suffers in opposition provinces especially in industries with initially higher efficiency, as measured by their return on assets. As industries respond to tightening financial constraints by shedding employment and assets, politically induced lending

\footnotetext{
${ }^{1}$ We use the terms 'aligned' and 'allied' interchangeably throughout the text. Either terminology refers to incumbent mayors affiliated with the ruling-party in central government, while 'non-aligned' or 'non-allied' refers to mayors affiliated with any of the opposition parties.
} 
potentially gives rise to long-lasting adverse effects on aggregate productivity and growth in these regions.

Our identification strategy builds on difference-in-differences estimates that exploit the greater susceptibility of state-owned banks to political pressure compared with private banks. We use cross-sectional variation in electoral competition and political alignment across localities to identify elements of tactical redistribution and rule out alternative explanations. On the one hand, private banks may also be subject to political influence (Chavaz and Rose, 2018; Akey et al., 2017) and they may respond to competition from state banks. In that case, our estimations constitute a lower bound for the true size of the political cycle in politically aligned regions.

On the other hand, we control for various sets of bank and province fixed effects, which help us control for unobservable and demand-driven explanations of the lending cycle, since local economic shocks correlated with the election cycle should affect private banks similarly. In addition, we collect novel data on the rewarding of investment incentives by the central government, which come with promises of job creation, and all new construction projects started by the public sector to test whether an electoral cycle in the distribution of public funds may drive our results. While there is suggestive evidence that public funds are channeled to political allies in the run up to elections, there is no corresponding evidence for opposition regions. We therefore believe that the political lending cycle is mostly driven by supply-side rather than demand-side factors. Nevertheless, we cannot fully rule out potential mechanisms in which firms adjust their borrowing, investment, and employment decisions based on expectations about future rewards or punishments by the central government. 
In our empirical setup, we take advantage of the Turkish electoral system, which differentiates between the election of district and metropolitan mayors, to create an exact match between political, credit, and real outcomes at the province level. Our identification is strongest in metropolitan provinces where a single mayor is elected by the majority of votes coming from all voters located in that province. ${ }^{2}$ This helps us derive precise estimates for political competition and avoid vote aggregation issues encountered by earlier studies. Furthermore, we draw on a newly available quarterly dataset of bank loans to explore the lending cycle in a higher frequency, which helps differentiate between competing theories of political cycles.

The literature on targeted redistribution distinguishes between constant patronage, which refers to rewarding core supporters (Cox and McCubbins, 1986), and tactical redistribution, which aims to achieve electoral gains by targeting politically competitive regions around elections Dixit and Londregan (1996). "Patronage" involves awarding areas in which the incumbent party might enjoy strong support. Such constituencies would absorb a disproportionate amount of resources regardless of the electoral cycle. "Tactical redistribution" predicts that resources will be directed towards swing districts either to change the election outcome, in which case we are more likely to see an impact prior to the election, or rewarding the party's strongholds, where one would expect to see a post-election impact. Our results pinpoint pre-election tactical redistribution over post-election rewarding or punishment of constituencies as the driver of the credit cycle, while we also find some evidence supporting the constant patronage argument during period further away from local elections.

\footnotetext{
2 Nevertheless, we show below that our results extend to all provinces in the country in the vast majority of our analysis.
} 
An important implication of our findings is that low frequency data may not be optimal to explore electoral cycles in bank lending, a point first made by Akhmedov and Zhuravskaya (2004) in the context of political budget cycles.

We contribute to two strands of the literature. First, we provide new evidence on political cycles and mechanisms underlying tactical redistribution. Inspired by theories of opportunistic political cycles, ${ }^{3}$ earlier studies investigate the effect of elections on governments' tax revenues and budget deficits. ${ }^{4}$ Evidence shows that such political budget cycles are prevalent across the world, especially in developing countries and young democracies (Akhmedov and Zhuravskaya, 2004; Shi and Svensson, 2006; Brender and Drazen, 2008). A more recent set of papers asks whether lending by state-owned banks follows a political cycle. Dinç (2005) finds cross-country evidence that government-owned banks raise lending in national election years compared with private banks. Cole (2009) finds that state banks in India extend more agricultural credit during election years, but with no tangible effect on agricultural output, especially in "swing" regions. Similarly, Carvalho (2014) shows that Brazilian firms eligible for state-bank lending employ more people in politically attractive regions near elections and in return, these expansions are likely to be financed by state-bank loans. Most recently, Englmaier and Stowasser (2017) find that German savings banks, which

\footnotetext{
${ }^{3}$ See Nordhaus (1975), MacRae (1977) and Rogoff and Sibert (1988).

${ }^{4}$ These studies explore the possibility that politicians in power may use the central government's fiscal muscles to boost the economy and improve their own reelection prospects. However, there is a chance that sophisticated voters might punish opportunistic governments as in Peltzman (1992), although this would require fully-informed voters with plenty of democratic experience (Brender and Drazen, 2005).

${ }^{5}$ Cole (2009) also finds that loan defaults increase after directed lending, which implies that election- induced loans are not used efficiently.
} 
are subject to political influence, change their lending behaviour in the run up to local elections.

In contrast to these studies, which uniformly find that political influence is used to expand credit to secure votes, we document how political power is associated with an aggregate reduction in credit. ${ }^{6}$ We document the drivers behind this reduction and the adverse effects that tactical redistribution creates on the real economy using data based on administrative records. The political lending cycle gives rise to aggregate financial constraints for firms located in politically misaligned regions, which respond by shedding jobs and assets, and suffer a decline in net sales. We do not find that firm entry is affected by these dynamics, which suggests that political lending operates through the intensive margin of firms. This is in line with a setting in which a central government may prefer enriching the (potentially connected) firms that already operate in allied regions while impoverishing (unconnected) firms located on the opposition side. We further document how politically induced lending targets firms and industries that are most able to create jobs, thereby confirming arguments from earlier studies that politicians have a particular interest in manipulating employment growth to help re-election chances. Finally, we show that such incentives are in turn compatible with constituents' voting behaviour across local elections in our sample.

Our second contribution to the literature is on how state-owned banks affect allocation of financial resources. While government ownership can help solve credit market failures that arise due to coordination problems or information asymmetries (Stiglitz, 1993), they could also end up serving the private interests

\footnotetext{
${ }^{6}$ Akey et al. (2017) document a similar negative association between political power and consumer credit in the U.S.
} 
of the politicians and result in a misallocation of financial resources (Shleifer and Vishny, 1994; Shleifer, 1998; La Porta et al., 2002). In a seminal paper, La Porta, Lopez-de Silanes, and Shleifer (2002) show that state ownership of the banking sector across countries is associated with lower levels of growth, financial development, and government efficiency. Sapienza (2004) uses loan-level data to find that Italian state banks charge lower interest rates to similar firms. This tendency strengthens as the political party associated with the state bank has more support in the region, implying financial favours for its supporters. Similarly, Khwaja and Mian (2005) present evidence that firms in Pakistan with a politician on their board benefit from lower rates and default more often when they borrow from government banks, but not from private ones. ${ }^{7}$

Our paper contributes to this literature by quantifying the costs of politically induced lending. We find that tactical redistribution is not simply a minor cost of the democratic process, but it can be associated with substantial misallocation of financial resources and job losses. We show that tactical redistribution leads to the initially more efficient industries in misaligned regions to suffer the most from credit constraints. This implies that aggregate productivity in these regions is likely to suffer in the longer run as the relatively more efficient industries are forced to shed jobs and assets.

The rest of the paper is organised as follows. Section 2 describes the recent history of the banking industry, institutional background, and politics in Turkey. Section 3 describes the data. Section 4 presents our empirical methodology and results

\footnotetext{
7 See also Leuz and Oberholzer-Gee (2006), who detect a negative relationship between political connect- edness of Indonesian firms and their foreign financing; this is consistent with the view that connected firms can obtain cheap financing from government banks and do not benefit from foreign financing.
} 
on tactical reallocation of credit. Section 5 documents the real effects of politically induced lending. We conclude in Section 6.

\section{Institutional Background}

\subsection{The Turkish Banking Sector}

The Turkish financial system is dominated by deposit-taking banks, which are the primary sources of funding in the economy as in other emerging markets. Both state-owned and private banks provide banking services through nationwide branch networks, and there are no local or regional banks. Banks primarily lend to corporates and households with no particular sectoral specialization, having left behind the episode of fiscal repression and funding government deficits of the 1980s and 1990s. During this earlier period, political interference was widespread in the banking system. For instance, during the coalition governments of 1990s, it was common practice to share control of state banks among coalition parties based on their vote shares (Önder and Özyıldırım, 2013).

The shift in Turkish banking activity toward private sector financing followed an intensive restructuring phase, which was instigated by the twin currency and banking crises that struck the country between 1999 and 2001. More than 15 banks failed during the episode and many were taken over by the country's Savings Deposit Insurance Fund (SDIF). An extensive reform package was initiated under the guidance of the International Monetary Fund (IMF) to strengthen the operational efficiency and financial stability of the banking sector and to remove political interference. The central bank gained its institutional independence by law, while an independent Banking Regulation and Supervision Agency (BRSA) was established to solve the conflict of interest 
problem in bank supervision. ${ }^{8}$ The BRSA was also given the sole right to issue new banking permits, which had been at the hands of the central government's Council of Ministers and therefore heavily politicised. In early 2003, BRSA pushed through the early adoption of Basel II capital adequacy standards, and a limited deposit insurance scheme replaced the previously unlimited coverage for all financial institutions a year later.

These reforms have undeniably improved the institutional quality of the Turkish banking sector, which escaped the global financial crisis of 2008-09 unscathed. They also arguably minimised government interference in banking, except via direct ownership. State authorities retain controlling shares in all three deposittaking state banks - Ziraatbank, Halkbank, and Vakıfbank-despite the fact that all three were initially aimed to be privatised as part of the restructuring programme. The IMF states explicitly in its 2002 Stand-By Agreement signed with Turkey that the government should "establish a common and politically independent board for Ziraat and Halk, reporting to the Treasury, and appoint new management who will apply commercial criteria to ensure profitability, and who will formulate privatization plans," and "resume privatization process for Vakıf," which had already contacted potential investors at the time. ${ }^{9}$

8 Until 2000, the Treasury and the Central Bank shared the responsibility for bank supervision. These institutions were not able to step in to prevent the excessive carry-trade tendency when weakly-capitalised banks started financing Turkish government debt with cheap borrowing from abroad and exposed themselves to massive currency risks (see Baum et al., 2010).

${ }^{9}$ The full text of the 2002 stand-by agreement is available on IMF's website: https://www.imf.org/external/pubs/ft/scr/2002/cr02136.pdf. There is a detailed appendix on banking reform, which reports on the progress: "The boards of the state banks were replaced by a joint board consisting of professional bankers with instructions to restructure their operations so as to bring them back to profitability and prepare them for eventual privatization. Direct political influences in the operations of the banks was thus dramatically reduced." 
Although both Halkbank and Vakıfbank eventually floated part of their shares via initial public offerings - Halk in 2007 and Vakıf in 2005 - the full privatisation of state banks did notmaterialiseinthecomingyears. ${ }^{10}$ The IMF noted in a 2004 consultation report: "Further restructuring and eventual privatization of the state banks was another focus of discussions, with many arguing that the initial momentum of reform had been lost."11 The Turkish government has argued during this time that privatisation of state banks would undermine their social function, especially in relation to Ziraatbank. The IMF notes in 2007:12

"State bank privatization would increase efficiency. After many delays, the IPO for 20-25 percent of the government's share in Halkbank is underway. Staff urged that the residual government stake be sold within the next year and the privatization of Ziraat (the second largest deposit-taking institution) launched at once. The authorities, however, are reluctant to commit to specific plans, noting that Ziraat serves a social function as the only financial institution with branches in rural areas."

As noted earlier, the central government has maintained majority control of all three state banks during our sample period, which starts around the time that these reforms took effect. This constitutes an ideal period to investigate the

\footnotetext{
10 The IPOs were far from smooth. For instance, although the privatisation of Halkbank was initially planned be carried out via the sale of a controlling stake, the plan was changed afterward and only around $25 \%$ of the bank's shares went on offer.

11 See Turkey: 2004 Article IV consultation: https://www.imf.org/external/pubs/ft/scr/2005/cr05163.pdf. IMF further notes that "the due diligence of Vakıf has been further delayed", while the Turkish authorities reiterate their commitment: "Our objective remains to privatize these banks [Halk and Ziraat] as soon as the restructuring is complete and when market conditions permit."

12 See Turkey: 2007 Article IV consultation:

https://www.imf.org/external/pubs/ft/scr/2007/cr07362.pdf.
} 
influence of the central government on state-owned banks, as direct ownership which the authorities retained despite earlier commitments to do otherwise appears to be the only channel through which it can exert pressure on the banking system.

Table 1 shows how deposit-taking banks in Turkey have evolved over the past two decades. Panel A indicates that the sector has shrunk in size considerably between 1999 and 2004 following the financial stability programme. In total 20 banks were closed down, while state banks became much leaner by shedding branches and personnel. ${ }^{13}$ However, both state and private banks flourished since then, expanding their branch network and employees considerably. The sector consolidated on the private side through entry or mergers involving new and foreign banks. Panel B shows that the formation of a uniform supervisory and regulatory system levelled the playing field for private and state banks. State banks have substantially improved their loan quality and capital buffers since 2004. More importantly, private and state banks have converged to a similar level of financial performance over time. This ensures that our identification strategy is immune to operational differences or balance sheet effects between these two sets of banks. State banks have retained an important role in the banking system as they typically control around a third of total banking assets, with similar market shares in both total deposits and lending.

\subsection{Politics and local elections in Turkey}

Turkey has been a parliamentary democracy with a multi-party political system during our sample period. The Prime Minister, typically the leader of a political

\footnotetext{
${ }_{13}$ Under the restructuring programme led by the IMF, 800 branches of Ziraat and Halk were closed and some 30,000 employees laid off. See IMF's Turkey: 2004 Article IV Consultation.
} 
coalition, served as the head of government and exercised executive powers with the Council of Ministers during our sample period of 2002-2017. ${ }^{14}$ The current ruling party, AKP (Adalet ve Kalkınma Partisi), has been in power since November 2002 and retained its majority of seats in parliament through several general elections. The AKP inherited the IMF-led reforms of 1999-2001 and successfully implemented them, bringing public expenditures under control, strengthening the overall quality of institutions, and starting accession negotiations with the European Union in $2005 .{ }^{15}$

Turkey is divided into 81 provinces (or cities) for administrative purposes, which are further divided into 923 districts. ${ }^{16}$ Each district corresponds to a constituency in a local election. Some of these districts jointly form the provincial center, which typically contains the largest population in a province. Out of the 81 provinces, 30 are designated as metropolitan municipalities. A metropolitan municipality consists of all districts within the borders of that province, and a metropolitan mayor is elected by the majority of votes cast in that province. ${ }^{17}$ The electorate in metropolitan areas also votes for district mayors on the same election day. Voters in non-metropolitan areas only vote for mayoral candidates of the district they live in. The major contest among political parties is to have their candidate

\footnotetext{
${ }^{14}$ Turkey switched to an executive presidential system in June 2018, in which the electorate votes for the president alongside members of the parliament. The role of Prime Minister is abolished as a result. However, the structure of local governments is unaffected.

${ }^{15}$ See Acemoglu and Ucer (2015) for a discussion of Turkish politics and institutions under the AKP rule.

${ }^{16}$ Turkey follows EuroStat's NUTS (Nomenclature of Territorial Units for Statistics) designation for regions. There are 81 provinces at the NUTS-3 level, 26 subregions at the NUTS-2 level, and 12 regions at the NUTS-1 level.

${ }^{17}$ As discussed below, this helps us have a better correspondence between election and credit data in metropolitan provinces.
} 
elected as the metropolitan mayor in metropolitan provinces, and as the mayor of the central district in the remaining provinces.

Local elections are held every five years on the same day throughout the country. Our sample period covers three local elections held in 2004, 2009, and 2014, at the end of March in each case. ${ }^{18}$ On the one hand, this means that we cannot exploit time variation across provinces in elections. On the other hand, it removes any bias from endogeneity of election timing, which may arise if early elections are called when the local economy is doing particularly well (Cole, 2009). Although early local elections are possible de jure in Turkey, de facto they do not exist in the country's political culture. We focus on political cycles based on local, as opposed to general, elections to identify possible effects on bank lending and economic outcomes. ${ }^{19}$ The reasons for this are twofold.

First, as Turkey gradually shifted from coalition governments to single-party governments over the past two decades, local elections have become more instrumental in expanding the power base of the ruling party. Mayors have become more visible in national politics, and some metropolitan municipalities have commanded substantial political clout. ${ }^{20}$ These developments are consistent with the political model of Brollo and Nannicini (2012), in which voters are unable to distinguish the sources of government transfers and political spillovers occur in favour of municipal governments. The central government may then use transfers to favour political friends or to punish political enemies at the local

\footnotetext{
18 Exact election dates are 28 March 2004, 29 March 2009, and 30 March 2014.

${ }^{19}$ General elections are held in different years from local elections, and frequently called early by the central government opportunistically. There were four national elections in our sample period: 2007, 2011, 2015 (June), and 2015 (November).

${ }^{20}$ Indeed, current President Recep T. Erdoğan served as mayor of Istanbul between 1994 and 1998, before he set up the AKP that has ruled the country since 2002. See İncioğlu (2002) and Sayarı (2014) for the rising importance of local elections in Turkey.
} 
level, since mayoral candidates can be important allies for the central government once elected (Brollo and Nannicini, 2012). In addition, the singleparty AKP government has rarely faced any competition at national elections during our sample period. Thus, it is reasonable to expect that any potential reallocation of resources should follow local elections, especially where the ruling party in central government faces real competition to "win" or "lose" certain provinces.

Second, province-level vote shares of political parties at national elections do not translate directly into the number of seats gained in parliament, and thereby into political influence over resource transfers. This is due to the presence of a relatively high election threshold, which requires each political party to receive at least $10 \%$ of the national vote to enter the parliament. This makes it impossible to have a clear measure of the actual province- level electoral contest, since votes for parties that fail to clear the national threshold are redistributed among remaining parties in each province. The number of legislators that go to parties with at least $10 \%$ of the national vote are artificially increased as a result. We believe that such uncertainty regarding the number of legislative seats that can be won at the province level deters the central government from pursuing a regional targeting policy. ${ }^{21}$ In contrast, competition in a local election is straightforward to quantify and more visible as it resembles a single-winner voting system, in which the party that gets the most votes wins the constituency. Therefore, our focus on local elections helps us understand tactical reallocation

\footnotetext{
${ }^{21}$ Baum et al. (2010) check for parliamentary election cycles in the Turkish banking sector from 1963 to 2007 and find no evidence of a meaningful difference between state and private banks. This could be due to two possible reasons. Either governments do not resort to such tactics for general elections, or political influence also affects private banks, as it is commonly believed to have been the case before 2001 .
} 
by the central government when it faces a clear competitive threat to win or lose a province.

\section{Data}

We use three main data sets in our analysis. Our first data set combines detailed banking information from the FinTürk database maintained by Turkey's Banking Regulatory and Supervisory Agency (BRSA). FinTürk provides province-level data at the quarterly frequency on both corporate and consumer loans extended by state, private domestic, and foreign banks beginning in the fourth quarter of 2007. These data constitute the universe of bank cash and non-cash loans in the country, include data on non-performing loans (NPLs), and cover all provinces by bank type. We also collect data on bank branches and deposits from FinTürk, again at the level of province and bank type. Separately, FinTürk provides a breakdown of corporate lending nationally by bank type and industry of borrower (following the EU's NACE Rev. 2) at a monthly frequency since 2005. We use this piece of information to construct credit market shares by bank type.

Our second dataset contains measures of real economic outcomes from firm-level administrative records. The Turkish Ministry of Industry (MoI) maintains a centralised database that collates various firm-level data sets that are collected by multiple public institutions and agencies. ${ }^{22}$ Researchers can submit information requests to the ministry to obtain data aggregated at a higher level than the most detailed level of the firm. For our purposes, we submitted multiple requests and obtained data sourced from the balance sheets and income statements of every

\footnotetext{
22 This centralised database is called Girişimci Bilgi Sistemi (GBS) in Turkish. See https:/gbs.sanayi.gov.tr/GbsHakkinda.aspx for a list of the public institutions contributing data, available data sets, terms of access, and sample reports.
} 
firm that is formally registered in the country. ${ }^{23}$ Specifically, we obtained the following variables aggregated at the 2-digit industry (following NACE Rev. 2), province, and year level using end-of-year documents: employment, net sales, total assets, short-term bank debt, and long-term bank debt. In addition, we obtained figures for the total number of establishments underlying these variables. These data essentially capture the universe of corporate activity in the country.

Our third data set consists of local election outcomes. We obtain information on district- and metropolitan-level votes for each political party from TurkStat. Based on these data, we create two political variables. The first is a measure of political competition (or contestedness) that captures the margin of victory/loss by the ruling-party ("allied") candidate against the most popular opposition ("non-allied") candidate. Formally, we start by con- structing a continuous Competition variable: Competition variable: Competition Con $_{t}=1-\left|\operatorname{Margin}_{p, t}\right|$, where $p$ stands for province, $t$ indicates the particular election, and Margin denotes the difference in the share of votes won by the ruling party's candidate and the most popular opposition candidate. Thus, Competition takes values between 0 and 1, with values closer to 1 indicating close electoral competition. To capture province-level competition, we work with the margin in the election of metropolitan mayors in metropolitan areas. For non-metropolitan areas, we use the corresponding value for the central district of the province.

One might worry that electoral contestedness is influenced by the lending behaviour of state-owned banks in the province, which might render Competition

\footnotetext{
${ }^{23}$ The MoI sources firm-level balance sheets and income statements from Turkey's Department of Revenue Administration (the equivalent body in the United States is the Internal Revenue Service). It sources employment information from Turkey's Social Security Institution (the equivalent body in the United States is Social Security Administration).
} 
potentially endogenous. Earlier studies have dealt with this issue by using a binary variable for political competition. We follow earlier studies in this regard and define an indicator variable of electoral competition. In particular, this dummy variable, Comp $p_{p, t}$, equals 1 when the variable Competition is above its sample median and 0 otherwise. We show below that our results are qualitatively unchanged when using either a continuous measure of contestedness or several other variants.

Our second political variable is a dummy for political alignment (or alliance), which indicates whether the ruling-party candidate wins (i.e., gets the highest number of votes) in that province or not. Recall that voters elect both district and metropolitan mayors in metropolitan provinces, while they elect only a district mayor in non-metropolitan provinces. However, our credit data are only available at the province level, which means that we need to aggregate voting outcomes to define a province-level measure of alignment. Previous literature deals with this problem by averaging voting outcomes across constituencies of a region (for instance, see Cole (2009)). However, this approach may be inappropriate in our setting. Unlike most previous studies, in which political pressure is applied by local governments on local state banks, our setting predicts political influence by the central government on national state banks. Thus, tactical reallocation not only depends on electoral competition in a province, but also crucially on whether the province is currently aligned with the ruling party in central government or not. ${ }^{24}$ This forces us to have a cleaner measure of alliance than averaging across districts.

\footnotetext{
24 Alliance with the central or federal government does not matter in the political settings of Sapienza (2004), Cole (2009) or Englmaier and Stowasser (2017), where locally elected governments have a direct influence on state banks that operate locally. Carvalho (2014) has a
} 
We tackle this problem by concentrating on the metropolitan mayors and, in nonmetropolitan provinces, on the central district mayors. This gives us a direct measure of alliance for each province. However, this procedure is still not ideal for non-metropolitan provinces, since some central districts - even though they are the largest by population within a province - do not always represent the political dynamics of the whole province. This can be seen in Figure 1, which shows the alliance of elected district mayors in two non-metropolitan provinces during 2004 elections. Panel A shows that in $\mathrm{Mu}, \mathrm{s}$, the only aligned district was the central district, where the electorate represented less than half of all voters $(48.3 \%)$ in that province. In contrast, the central district in Kastamonu (Panel B) was not aligned with the ruling party; however, a large portion of the province (43.9\% by votes) was still governed by an aligned mayor. If politically induced lending occurs at the level of districts, this may create some measurement error and lead to attenuation bias in our estimates. We therefore base our main findings on results from metropolitan provinces, where the elected mayor represents the whole electorate and acts as the main political figure in the province. ${ }^{25}$ Our estimates from the metropolitan sample should thus be free of measurement error. Nevertheless, we will also report our findings from a full sample that also includes non-metropolitan provinces.

Table 2 presents summary statistics for the main variables in our analysis. During our sample period, $60 \%$ of provinces on average are classified as politically

setting similar to ours, in which the central government in Brazil manipulates state-bank lending to help reelect allied state governors.

${ }^{25}$ Given the rising importance of metropolitan mayors in the Turkish political sphere and that the vast majority of economic activity takes place in metropolitan provinces, the central government is more likely to strategically target them. For instance, $85 \%$ of total lending by state banks and $95 \%$ of total lending by private banks is concentrated in metropolitan provinces on average during our sample period. 
aligned with the ruling party. There is a fair degree of electoral competition, as the win margin in the median province is 14 percentage points. Figure 2 shows the level of political competition and mayors' alignment with the governing party for metropolitan provinces based on voting outcomes for each local election. Darker tones indicate greater electoral contestedness, which has increased throughout the sample period, and different colours for the governing and opposition parties indicate that around a half of metropolitan provinces are politically aligned. It is this variation in local political competition and alignment that we exploit in our identification strategy.

\section{Political Lending Cycles}

\subsection{Identification Strategies}

We start with a simple difference-in-differences (DD) methodology in a balanced panel set- ting to investigate political cycles. We use government ownership of banks as our treatment, which captures political influence by the central government over local lending. Our control group includes all privately-owned banks that operate in the same provinces (i.e. we aggregate lending by domestic private and foreign banks). If there is politically induced lending, then political pressure on state-owned banks should intensify around election years. We therefore expect state banks to alter their lending behaviour closer to elections compared with private banks. To the extent that the effect of politicians on lending decisions by state banks is stable over time, or that politicians also influence lending by private banks around elections, our DD estimates provide a lower bound for the true size of politically induced lending.

The essence of DD relies on the premise that treated and untreated groups share a parallel trend in the absence of treatment (Angrist and Pischke, 2009). Figure 3 
shows the evolution of total cash loans extended by state and private banks in the top panel. Aggregate credit has been on a stable trajectory for both types of banks throughout this period. Exceptions to these trends appear in 2009 and 2016, when lending by private banks have actually contracted due to significant slowdowns in the Turkish economy. ${ }^{26}$ This has further increased state banks' market share of aggregate lending, which has been on an upward trajectory during the sample period. Importantly, however, the bottom panel of Figure 3 shows that this long-run trend has been similar across all provinces regardless of their political alignment or degree of electoral competition.

Our DD strategy should be immune to year-specific shocks to the extent that economic fluctuations affect all provinces or bank types similarly. Nevertheless, we carry out extensive checks to ensure that no single election or unobserved province- or bank type-specific shocks drive our results. Moreover, we include the number of local branches by bank type in each of our regressions. This should help us control for any long-term credit demand and supply conditions in each province by bank type, and potential sorting of banks that may be linked to regional unobservables.

As discussed before, we mainly search for tactical redistribution prior to elections in our context while still being to open to the possibility of patronage in nonelection years. To test this idea, we make use of the full time-series and crosssectional dimensions of our dataset. Formally, we adopt a triple difference-indifferences (DDD) model and test whether highly contested provinces get more/less credit from state banks around elections when compared with private banks. The DDD model allows us to control for a full set of province-by-year or

\footnotetext{
26 Turkey experienced a recession in 2009 due to the global financial crisis, while growth slowed down in 2016 due to political uncertainty induced by a failed coup attempt in July.
} 
bank type-by-year fixed effects. This helps us eliminate any unobserved province- or bank-specific shocks that may be correlated with election cycles.

A key feature of our identification comes from the fact that we test the differential allocation of state-bank credit towards swing provinces over the entire election cycle instead of only comparing election versus non-election years. This gives us a full picture of the evolution of political pressure on state-banks, and provides a much more powerful test of election-induced lending. In fact, bank credit cycles over time could be explained by reasons unrelated to politics (such as banks' different sensitivities to policy uncertainty). Cross- sectional allocation of credit towards certain provinces could be related to province-specific factors (such as concentration of certain sectors in certain provinces). However, it is difficult to explain why such cross-sectional relationships would vary over time specifically around elections without resorting to an explanation based on political incentives (Cole, 2009). We return to this discussion below after we present our main results.

\subsection{Is there an election cycle in state-bank credit?}

We start by testing whether state banks adjust their overall lending behaviour around elections compared with private banks using a standard DD model. Consider:

$$
\log _{\text {Credit }}, p, t=\beta_{\tau} \text { StateBank }_{b} \times \text { Election } t+\tau+\delta X_{b, p, t-1}+\theta_{b}+\gamma_{p}+\lambda_{t}+\varepsilon b, p, t
$$

where $b$ is an index for bank type, $\mathrm{p}$ stands for province, and $\mathrm{t}$ denotes yearquarters in the quarterly data. The dependent variable, LogCreditb,p,t, is total cash loans (in logs). StateBankb is a dummy variable indicating state-owned banks. Election $t$ equals 1 in the quarter that a local election takes place and the preceding three quarters, and 0 otherwise. This gives us a precisely estimated pre-election effect. 
The main advantage of working with quarterly data is that we can pinpoint exactly how state banks alter their lending behaviour before and after elections. We therefore extend our analysis to the whole cycle by employing a rolling definition of Election ${ }_{t+\tau}$, where $\tau$ corresponds to the quarters before and after elections. For instance, Election $t_{-2}$ equals 1 for two to six quarters prior to an election, and 0 otherwise. $\tau$ takes values from -10 to +10 , indicating the number of quarters around elections and thereby capturing the full election cycle spanning five years.

Our coefficient of interest in equation (1) is $\beta \tau$ and captures the behaviour of state banks compared with private banks at each point over the election cycle. We include fixed effects at the levels of bank type, province, and time in our baseline. These capture any unobservable and time invariant factors related to bank types and individual provinces, and aggregate shocks in that quarter. Lastly, $\mathrm{X}_{b, p, t-1}$ includes the lagged presence of bank branches, which control for local market shares separately for each bank-type. ${ }^{27}$ We cluster standard errors in all of our regressions at the province level, since local credit outcomes are likely to be correlated across time within localities.

Table 3 presents results in the immediate run up to a local election (i.e., $\tau=0$ ) for the sample of metropolitan provinces in columns (1)-(4) and for the full sample in columns (5)-(8). In both samples and across different sets of controls, state banks reduce lending in the four quarters up to and including elections when compared with private banks. This is the case even when time trends are

\footnotetext{
${ }^{27}$ We observe the number of bank branches by province and bank type, but control for their presence using an ordinal variable by assigning them into 30 groups. This is because the number of bank branches itself might be affected by the local election cycles we are trying to identify, giving rise to a "bad control" problem (Englmaier and Stowasser, 2017). We show in Section 4.5 that our results are robust to different definitions of covariates.
} 
included by province (columns (3) and (7)) or when a full set of province-by-time factors are non-parametrically controlled for (columns (4) and (8)). In the latter case, all relevant local shocks to credit demand such as unemployment or growth are absorbed, and our coefficient estimates hardly differ from alternative specifications. Point estimates range from $-7.5 \%$ in the full sample to $-14.6 \%$ in the metropolitan sample; all coefficients are estimated with a high level of statistical significance and point to a substantial reduction in lending by state banks relative to private banks.

Figure 4 plots coefficients for the entire election cycle from regressions that include our baseline controls and province time trends. Each plotted coefficient corresponds to a single regression with an estimate of $\beta \tau$ as $\tau$ varies between -10 and +10 . Hence, coefficient estimates for $\tau=0$ in Panels A and B equal estimates reported in columns (3) and (7), respectively, of Table $3 .{ }^{28}$ Lending by state banks hits rock bottom compared with private banks either in the quarter in which elections take place or just before. In metropolitan provinces, state-bank credit hits a trough at $-12.5 \%$ one quarter before local elections, while it hits a trough at $-7.5 \%$ in the election quarter in the full sample. This negative effect is estimated with precision in the four quarters leading up to the election and persists for another four to five quarters following it. These findings clearly illustrate that state bank credit is subject to a cycle around local elections. State banks reduce their lending prior to local elections and boost it afterwards compared with private banks.

This finding may at first seem counter-intuitive, since most earlier studies document a rise in state-bank lending in the run up to elections. There are two

\footnotetext{
${ }^{28}$ Our regressions for the full election cycle presented in figures below always include province time trends.
} 
reasons why earlier findings and ours actually complement, rather than contradict, each other. First, our focus is on local election cycles rather than general elections that have been studied by previous literature (Dinç, 2005). In local elections, a central government's control over state banks leads to different incentives across provinces depending on their political attractiveness (Brollo and Nannicini, 2012; Carvalho, 2014). Therefore, local elections do not necessarily imply an overall pre-election credit boom in the country. Second, earlier studies that investigate local elections and bank credit typically have political settings in which local governments are in direct control of local state banks (Cole, 2009; Englmaier and Stowasser, 2017). In that case, each local government would have an incentive to encourage pre-election lending to increase their re-election prospects, and thus there would be an overall credit boom in the country before elections. However, our political pressure channel goes from central government to state banks, which predicts a reallocation of credit across provinces but does not necessitate a rise in aggregate lending.

Although we find evidence that state banks' lending behaviour changes around elections, it is important to note that such intertemporal reallocation does not strictly imply political manipulation. It is possible that state banks are more sensitive than private banks to overall political uncertainty induced by local elections. As a result they may choose to postpone lending decisions until after elections take place. Since we document a recovery in state-bank lending a few quarters after elections, we do not yet rule out this possibility.

\subsection{Is there tactical redistribution across provinces?}

We now test the existence of political incentives behind the intertemporal reallocation of state-bank credit over the local election cycle. Note that redistributing credit is not costless and that the central government's incentive to 
distort bank policies increases with the marginal utility of receiving additional votes (Englmaier and Stowasser, 2017). Undoubtedly, this marginal utility is highest where a small number of votes can determine the outcome; that is, in closely contested elections. We should therefore find stronger reallocation of credit in provinces with high electoral competition if the election-induced cycle is driven (at least partly) by political goals. To test this idea, we extend Equation (1) to a triple difference-in-differences model as follows:

$$
\begin{aligned}
\text { LogCredit }_{b, p, t}= & \beta_{\tau} \text { Comp }_{p, t} \times \text { StateBank }_{b} \times \text { Election }_{t+\tau}+\alpha_{1} \text { Comp }_{p, t} \times \text { StateBank }_{b} \\
& +\alpha_{2} \text { StateBank }_{b} \times \text { Election }_{t+\tau}+\alpha_{3} \text { Comp }_{p, t} \times \text { Election }_{t+\tau} \\
& +\alpha_{4} \text { Comp }_{p, t}+\delta X_{b, p, t-1}+\theta_{b}+\gamma_{p}+\lambda_{t}+\varepsilon_{b, p, t}
\end{aligned}
$$

where Comp $p_{p, t}$ represents the binary competition variable created earlier. As discussed in Section 3, our measures of political variables are most reliable for metropolitan provinces. We will therefore present our tactical redistribution results based on this sample.

Notice that Compp,t is time-varying and we need to make an assumption on political contestedness for non-election quarters. We follow the literature in assuming that competition for the next two-and-a-half years (or ten quarters) after an election is captured by the previous election outcome, while it is captured by an upcoming election outcome for the two-and-a-half years before an election in that constituency (Cole, 2009; Englmaier and Stowasser, 2017). Despite the aforementioned endogeneity concern between credit as a dependent variable and competition as an independent variable in Equation (2), we believe it is reasonable to assume that political redistribution of credit would not change 
election outcomes by such a high margin as to make an election uncompetitive. ${ }^{29}$ We therefore show in Section 4.5 below that our results are robust to a number of alternative definitions of political competition.

Our main coefficient of interest in Equation (2) is the triple-interaction effect denoted by $\beta_{\tau}$. It captures the impact of greater political competition in a province on the difference between state-bank and private-bank lending in the quarters running up to an election $(\tau=0)$. The two-way interactions underlying the triple effect absorb economically important effects and are also of interest. Based on the discussion in Section 4.1, $\alpha_{1}$ accounts for the possibility that state banks may differ in their local lending behaviour depending on the political attractiveness of a province independent of an election cycle. Similarly, $\alpha_{2}$ captures any electioninduced effects that may differ between the two types of banks, while $\alpha_{3}$ accounts for any responses to elections that may vary across provinces based on political attractiveness but not bank types. Hence, the model captures any shocks to banks or provinces that may be correlated with either the electoral cycle or the degree of contestedness in an election. We will saturate this model further by a full set of province-time and bank-time fixed effects to capture all time-varying and province- or bank-specific unobservable shocks.

A central government's incentives to redistribute resources across provinces depends not only on political attractiveness, but also on whether the incumbent mayor is a political ally or not. In particular, if a province is currently ruled by a mayor from the ruling party, then the central government has an interest in increasing voter appreciation and the re-election chances of the incumbent

29 This does not mean that the central government would not be able to win an election by manipulating credit. It means that any extra lending allocated to a province through state banks would not be able to change the nature of the election, making it competitive or uncompetitive. 
mayor. However, the opposite would be true if a mayor from opposition is currently in charge. It is thus optimal from the central government's perspective to increase credit and positively influence economic conditions in politically aligned provinces, and to decrease credit and reduce economic activity in nonaligned provinces. Therefore, we divide our sample into two subsamples based on current mayoral incumbency and condition our expectations of $\beta_{\tau}$ on political alliance. If tactical redistribution exists, we expect $\beta_{\tau}>0$ in aligned provinces and $\beta_{\tau}<0$ in non-aligned provinces just prior to the elections. As for the constant patronage argument, we would expect the central government to favour its strong supporters (i.e. less competitive areas) in allied provinces and more competitive areas in non-allied provinces during non-election times. Hence, we would expect $\beta_{\tau}$ to switch its sign further away from elections (for very low or high values of $\tau)$.

Table 4 shows estimates of Equation (2) when $\tau=0$ on a sample of metropolitan provinces, for which our identification strategy is cleanest. In line with a tactical redistribution mechanism, state banks lend more in provinces with higher political contestedness and an aligned incumbent mayor (i.e., $\beta_{\tau}>0$ in columns (1)-(5)), while they significantly reduce credit in provinces with higher political contestedness but ruled by an opposition mayor (i.e., $\beta_{\tau}<0$ in columns (6)-(10)) when compared with private banks. We report estimates in each sub-sample with varying degrees of saturation in our fixed effects and find especially strong results in non-aligned provinces. Our point estimates are unchanged but estimated with less precision when we include the full set of province-time and bank-time fixed effects. In the four quarters immediately before a local election takes place, state banks are estimated to increase their lending by around 13\% compared with private banks in con- tested areas with an aligned mayor, but reduce it by around $9 \%$ in contested areas with a non-aligned mayor. These 
effects are sizable given that our credit measure covers the entire state-bank lending in a province. They are also comparable to results by Cole (2009), who finds that state banks increase agricultural lending by 5-10 percentage points in an election year.

Figure 5 illustrates the presence of tactical reallocation over the full election cycle by plotting coefficient estimates of the triple-interaction term $\left(\beta_{\tau}\right)$ for different values of $\tau .{ }^{30}$ Targeted redistribution starts around four quarters prior to an election, and is strongest in the immediate run up to it. There is strong evidence in the bottom panel that politically non- aligned provinces suffer from a relative reduction in lending by state banks for an extended period in the run up to closely contested elections. We see the exact opposite trend in the top panel of politically aligned provinces. There is also some support for the constant patronage hypothesis as $\beta_{\tau}$ switches signs when the central government does not have electoral concerns but would rather favour areas where it faces stronger support in general, although this effect is not always statistically significant.

We believe that this visual representation of state-bank credit reallocation over the election cycle provides strong evidence of political incentives behind statebank lending. There could be alternative explanations for why state banks in general would behave differently around elections. For instance, state banks may be more cautious in their lending in provinces with greater political uncertainty. However, this would imply that state banks should cut back on lending in all politically contested provinces regardless of the alignment of incumbent mayors, which is at odds with the evidence. There could also be reasons why certain provinces get a higher share of state-bank loans than others. State banks may

\footnotetext{
30 The exact model used for the estimates shown in the figure includes our baseline controls and province time trends as in Columns (3) and (8) in Table 4.
} 
specialise in lending to certain industries and unobserved shocks to these industries may drive part of the lending cycle. However, such effects should be captured by our full set of province-by-time fixed effects, whose inclusion leaves our main estimates unchanged. It is difficult to explain why cross-sectional relationships would vary in different directions based on local political alignment and exactly prior to local elections.

In order to shed more light on political incentives, we explore the channels through which the central government engages in tactical redistribution. Our aggregate credit data can be broken down by lending to different segments of the economy. This allows us to test whether targeted lending occurs in certain segments but not others, which helps us understand what voters respond to. On the one hand, politicians may try to induce a quick and direct impact on voters by raising their instant consumption. Healy and Lenz (2014) find that voters judge U.S. presidential candidates on the election-year economy because this is the most immediately available metric to them for judging a president's performance. However, given that province mayors have no direct control over bank credit supply in Turkey, it is difficult to argue that a change in consumer loans would have a direct impact on consumers' perception about the incumbent mayor.

On the other hand, politicians may be tempted to use bank credit to boost or contain corporate activity in a region. This would be more likely to influence voting patterns if corporates have a say in local politics and voters - at least partly - attribute corporates' economic outcomes to local politicians. For instance, Carvalho (2014) finds evidence in line with this view and shows that the central government in Brazil provides favourable credit to firms in politically aligned regions, who in turn expand employment to increase the re-election chances of 
incumbents. Although the consumer and corporate channels are not mutually exclusive, we expect the latter to be dominant in the Turkish political setting given its similarity to that of Brazil.

Figure 6 plots estimates of Equation (2) separately for corporate and consumer loans for different values of $\tau$. Panel A confirms our expectation that tactical redistribution is mainly targeted at corporate loans. The estimates are sizable and statistically significant for both aligned and non-aligned provinces in the case of corporate loans. The positive impact in aligned provinces peaks precisely in the election quarter, while the negative impact in non- aligned provinces hits the bottom one quarter prior to the election. There is also evidence that these patterns reverse in periods away from elections, supporting the notion that the central government might be pursuing patronage in those quarters. In contrast, estimates for consumer loans presented in panel B are uniformly insignificant and show no visible pattern around elections. These patterns are consistent with a setting in which political lending is channelled to segments of an economy where it could signal business skills for the incumbent mayor.

Does tactical redistribution of credit operate through state banks' existing clients or at the margin? Unfortunately our data do not allow us to observe how lending to the marginal borrower adjusts over time. We therefore adopt an indirect approach and estimate Equation (2) with NPLs as a share of total cash loans on the left hand side. If banks grant loans to applicants successively based on credit quality and state banks adjust lending to the marginal borrower prior to an election, then we would expect post-election default rates on loans to differ between state and private banks. Figure 7 shows the election cycle in share of NPLs. While there does not appear to be a clear cycle in politically aligned provinces, we find a strong drop in the share of NPLs in state bank portfolios in 
non-aligned provinces up to six quarters following a local election. As the average maturity of loans in Turkey lies between one and two years, this timing in default rates is consistent with state banks cutting back on lending to the marginal borrowers in non-aligned provinces.

Our results show that the central government's reallocation of state-bank credit targets firms' credit access and aims to influence local economic and voting outcomes through the corporate channel. State banks seem to increase the volume of credit to existing clients in politically aligned provinces, which is consistent with these firms being politically connected, but reduce it at the margin and also possibly for existing clients in non-aligned provinces. This leads us to investigate the effects of such redistribution on economic activity, and how changes in activity affect voter preferences, in Section $5 .{ }^{31}$ Before we do so, however, we document this political lending cycle over a longer time period, present robustness checks, and discuss alternative mechanisms underlying our findings.

\subsection{Testing for the lending cycle in yearly data}

We use quarterly data for our baseline estimations, which allow us to differentiate between pre- and post-election effects. In this sub-section, we alternatively use annual bank credit data provided by the Turkish central bank to check whether a lending cycle exists in the longer term. These data provide the year-end total cash loan exposure of each bank type across all provinces from 2003 to 2017. Hence, we can utilise additional variation due to the local elections that took place in 2004. We re-estimate Equation (1) with these yearly data, where

\footnotetext{
${ }^{31}$ We will show in Section 5 that politically induced lending indeed affects corporates' credit constraints, which respond by adjusting their employment, and that voter support for incumbent mayors reacts to changes in local employment.
} 
$\tau$ now refers to years around local elections. Electiont now equals 1 in the year before a local election, and 0 otherwise. Since all three local elections are held in March, this definition ensures that we capture a pre-election rather than a postelection effect in the yearly regressions.

Results are in Appendix A. In line with our earlier findings from quarterly data, Table A.1 shows that state banks reduce their lending in the year just before a local election when compared with private banks. Estimates suggest that statebank lending is between $12.5 \%$ and $17.5 \%$ lower compared with private-bank lending in election years. In Table A.2, we show that this result is not driven by a particular local election in our sample period. That is, we re-run our regressions each time dropping one election cycle at a time and confirm that our results are qualitatively unchanged across different samples. Figure A.1 shows results for the full election cycle from regressions that include our baseline controls and province time trends. Each plotted coefficient corresponds to a single regression with an estimate of $\beta_{\tau}$ when $\tau$ is equal to $-2,-1,0,+1$ or +2 . The figure shows that state banks curb credit with respect to private banks in an election year. However, they increase lending on a larger scale than private banks directly afterwards. This cycle seems slightly stronger in metropolitan provinces than in our full sample.

To test for the presence of tactical redistribution over a longer period, we reestimate Equation 2 with yearly data. ${ }^{32}$ We confirm in Table A.3 that politically aligned provinces benefit from a relative rise in credit supply by state banks when elections are closely con- tested, while non-aligned provinces suffer from a relative reduction. Our yearly regressions of tactical reallocation return estimates

\footnotetext{
${ }^{32}$ We report results on a sample of metropolitan provinces, for which our identification strategy is cleanest.
} 
that are higher than our quarterly estimates, and they are also estimated with greater statistical precision. Figure A.2 reports yearly estimates for the full election cycle. In provinces that are politically aligned with the ruling party, state banks lend more than private banks in the election year especially when political competition is high, and this effect persists in the post-election period. In nonaligned provinces, the drop in state-bank lending in the election year similarly persists one year after the election before recovering. These findings suggest that the central government may continue its tactical redistribution even after elections by rewarding constituencies in which it narrowly won, and punishing regions in which it narrowly lost elections. Consistent with the view that the central government favours its strongholds in the absence of election concerns, $\beta_{\tau}$ switches signs as it moves further away from local elections.

\subsection{Robustness checks}

We carry out a number of robustness checks, which are all reported in Appendix B. As tactical redistribution of state-bank credit appears to be concentrated on the corporate sector, we carry out these exercises using corporate loans as our dependent variable using quarterly data. In unreported results, we confirm for each exercise that there is no political lending cycle in consumer loans. ${ }^{33} \mathrm{We}$ report estimates of $\beta_{\tau}$ in Equation (2) including baseline controls and province time trends for the full election cycle for each of the following exercises.

As a first round of checks, we re-estimate Equation (2) with alternative definitions of political contestedness, Compp,t. In our baseline definition, our competition dummy takes the value of 1 for the upper $50 \%$ of the continuous

\footnotetext{
${ }^{33}$ We have also conducted each set of our robustness checks with annual data, which are available upon request.
} 
competition variable in the pooled sample of province-years, and 0 otherwise. Defining the competition dummy alternatively as the upper $25 \%$ of the continuous variable (Figure B.1), using the 50\% cut-off for each election one at a time (Figure B.2), or simply using the continuous competition variable itself (Figure B.3) all return qualitatively identical results. Furthermore, results remain similar when we measure political competition at a local election using the previous election's outcomes (Figure B.4).

In a second round of checks, we employ alternative controls in $X_{b, p, t-1}$ in Equation (2). Our baseline control of bank branches is an ordinal variable of 30 ranked clusters because branch presence itself might be affected by the local election cycles we are trying to identify. Our results remain unchanged when we instead control for bank branches in continuous log form (Figure B.5), or customer deposits alternatively (Figure B.6). Customer deposits are arguably less of a bad control if the central government has less influence over its distribution in provinces, but more so if customers adjust their deposits with the election cycle, for instance due to flight to safety when political uncertainty is high.

In a third round of checks, we confirm that our results are not driven by the biggest cities in the sample or one of the three local elections. In particular, dropping the three largest metropolitan cities - Istanbul, Ankara, and Izmir (Figure B.7) - or dropping one local election at a time in our yearly regressions (Figure B.8) does not alter our qualitative results.

Finally, we account for the possibility that our reference group in our estimations may contain some heterogeneity in itself. In particular, our baseline estimates merge domestic private and foreign banks into a single private category. However, recent research suggests that private banks are also subject to political pressure (Akey et al., 2017; Chavaz and Rose, 2018). In our context, one may 
conjecture that domestic private banks are also subject to the central government's political influence, and foreign banks less so. We therefore exclude all lending by foreign banks and simply treat domestic private bank lending as our reference category as a check. If domestic private banks are also subject to the central government's political influence, then estimates from this robustness check should be biased downward. We do not find this to be the case (Figure B.9). In fact, estimates are often larger than our baseline, suggesting that possible political pressure on domestic private banks is unlikely to affect our results.

\subsection{Additional mechanisms}

Our results so far are consistent with a supply-side story of state-owned banks actively adjusting their lending practices in provinces with closely contested local elections. Two pieces of evidence lend credibility to this interpretation. First, our results on tactical redistribution are immune to the inclusion of province-time fixed effects, using alternative control variables, and estimations on different subsamples. Unobservable demand factors are therefore unlikely to drive our findings. Second, state-owned banks appear to adjust their lending precisely in a way that may help increase electoral support for politically aligned incumbent mayors and decrease it for non-aligned mayors. Nevertheless, we explore three alternative explanations that may arise from the demand side.

First, we explore the importance of political uncertainty for the supply of bank credit and how this varies by bank type. A rich body of work documents that firms and households delay or cut back on investment and borrowing in the face of political uncertainty. ${ }^{34} \mathrm{~A}$ challenge to this argument is that uncertainty should

${ }^{34}$ See for instance Julio and Yook (2012); Gulen and Ion (2015); Jens (2017); Di Maggio et al. (2017). 
affect corporate decision-making similarly in both aligned and non-aligned provinces. That is, we would expect both state-owned and private banks to see a reduction in their lending volumes in provinces with the greatest electoral competition regardless of the incumbent mayor's alignment. We therefore estimate the following DD model:

$$
\text { LogCredit }_{b, p, t}=\beta_{\tau} H I_{p, t} \times \text { Election }_{t+\tau}+\alpha_{1} H I_{p, t}+\delta X_{b, p, t-1}+\theta_{b}+\gamma_{p}+\lambda_{t}+\varepsilon_{b, p, t}
$$

where $H I_{p, t}$ is an indicator variable for the upper half of a Herfindahl index of local political competition and proxies uncertainty. ${ }^{35}$ Figure B.10 in Appendix B shows no evidence at all - from regressions on either quarterly (panel A) or yearly (panel B) data - that political uncertainty is associated with a change in lending at any point of the election cycle.

We push this line of inquiry further to tease out whether state banks are particularly vulnerable to political uncertainty. If state banks tend to work relatively more with firms that have greater sensitivity to local politics, then they may cut back on lending prior to an election as a result of reduced credit demand by such firms. ${ }^{36}$ We therefore estimate the following DDD model:

${ }^{35}$ The Herfindahl index for electoral competition is defined as: $1-\sum_{i \in I}\left(\text { VoteShare }_{i, p, t}\right)^{2}$, where VoteSharei,,$t$ denotes each political party's vote share in province $p$ and time $t$. We use a dummy variable instead of the continuous index to guard against the possibility that credit reallocation might affect political uncertainty.

${ }^{36}$ Note that we would be under-estimating the impact of politically induced lending in politically aligned provinces if state banks indeed lend more cautiously prior to politically uncertain elections. 


$$
\begin{gathered}
\text { LogCredit }_{b, p, t}=\beta_{\tau} \text { HI }_{p, t} \times \text { StateBank }_{b} \times \text { Election }_{t+\tau}+\alpha_{1} \text { HI }_{p, t} \times \text { StateBank }_{b} \\
+\alpha_{2} \text { StateBank }_{b} \times \text { Election }_{t+\tau}+\alpha_{3} H I_{p, t} \times \text { Election }_{t+\tau} \\
+\alpha_{4} H I_{p, t}+\delta X_{b, p, t-1}+\theta_{b}+\gamma_{p}+\lambda_{t}+\varepsilon_{b, p, t}
\end{gathered}
$$

Figure B.11 shows that $\beta_{\tau}$ is estimated with a negative, but statistically insignificant, sign in the quarters leading up to a local election in panel A. This suggests that while state banks may indeed be more cautious prior to local elections, there is not sufficient evidence that political uncertainty would explain our findings. Results from yearly data in panel B similarly show no such evidence.

Second, we explore whether there are other demand factors correlated with the election cycle. In particular, the behaviour of private firms and banks can be politically influenced if they benefit from public funds (Carvalho, 2014; Chavaz and Rose, 2018). It is possible that the central government engages in a reallocation of public contracts, investment or funds around local elections that favour its allies and punishes opponents. To the extent that firms receiving these public funds use state bank credit relatively more, this could give rise to a lending cycle that is induced by firm-level demand.

To test this particular mechanism, we put together two new databases from publicly available data. The first database contains investment incentives issued by the central government from 2003 onwards. These incentives are administered by the Ministry of Economy and constitute Turkey's main investment promotion programme. ${ }^{37}$ They are available to both foreign and domestic investors through

\footnotetext{
37 The government maintains a website in English and provides details on this scheme here: http://www.invest.gov.tr/en-US/investmentguide/investorsguide/Pages/Incentives.aspx
} 
an "Investment Incentive Certificate", which is obtained from the Ministry following an evaluation of the investment project. Recipients are published in the Official Gazette every month alongside the amount of their proposed investment, number of jobs they promise to create, and the particular incentives they are entitled to receive based on the region of investment. Over the 2003-2017 period, a total of 56,241 incentive certificates have been issued with a total of TRY 824 billion in capital investment and just over 2 million new jobs proposed by recipients.

We aggregate the data on incentives to the province level at a quarterly frequency and estimate the following DD model with baseline fixed effects and provincetime trends:

$$
\text { LogPublicFunds }_{p, t}=\beta_{\tau} \text { Comp }_{p, t} \times \text { Election }_{t+\tau}+\gamma_{p}+\lambda_{t}+\gamma_{p} \times t+\varepsilon_{p, t}
$$

where PublicFundsp,t measures the total number of investment certificates issued to companies in province $p$ in year-quarter $t$. We alternatively use as a dependent variable (log) total number of new jobs that recipients of the investment certificates promise to create. If these certificates are allocated based on political incentives, then promised job creation should go up in politically aligned provinces and down in non-aligned provinces prior to a local election when there is high electoral competition. As domestic investors are more likely to respond to political influence than foreign investors, we focus on the incentive certificates rewarded to the former. ${ }^{38}$

Figure B.12 shows the results for the number of certificates in the top panel and promised job creation in the bottom panel. We find evidence for a drop in the

\footnotetext{
${ }^{38}$ Indeed, the vast majority of incentive certificates, 53,134 out of a total of 56,241, have been awarded to local investors during the sample period.
} 
number of certificates prior to local elections issued to firms in provinces that are politically contested and non- aligned with the central government. The expected increase in aligned provinces is not estimated with statistical significance. However, there is strong evidence that promised job creation moves in line with a tactical redistribution channel. Firms that promise to create more jobs in politically contested provinces are awarded more incentive certificates around local elections if they are in a politically aligned province, but they are awarded fewer certificates if they are in non-aligned provinces. It is important to note that there is no requirement by the government for the recipients of incentives to work with state banks rather than private banks. However, to the extent that this occurs, the reallocation of government incentives around elections can explain part of the variation in the lending cycle.

The second database we create to test the reallocation of public funding mechanism draws on construction permits issued by local municipalities. These permits are a standard requirement for any entity in Turkey to start a construction project and provides details on ownership, intended use, and other parameters. ${ }^{39}$ We collect data on the number of buildings and building area covered on all new construction projects initiated by the public sector during the 2003-2017 period from the Turkish Statistical Institute. We aggregate these data to the province level at a quarterly level and estimate Equation (5).

Figure B.13 shows the results for number of buildings in the top panel and area covered in the bottom panel. There is some evidence that the public sector may be constructing more buildings in politically aligned provinces in the run up to

\footnotetext{
${ }^{39}$ Data include the universe of construction, including projects for housing, office space, warehouses, industrial buildings, schools and libraries, and mosques among others. The vast majority of construction activity is in housing, both for private and public entities.
} 
an election, but this finding is not supported when we look at total building area. We also do not find any particular cycle in public construction in non-aligned provinces. It is therefore unlikely that the public sector's new investments in housing or other construction projects would drive the lending cycle identified earlier. These results also do not support a social lending story, by which state banks allocate credit to further social objectives and synergies between the central government and allied incumbents lead to better implementation or screening of socially desirable projects (Carvalho, 2014).

Finally, we explore whether corporates adjust their borrowing and investment policies because of expected rewards or punishments to local constituencies either directly or via changes in the allocation of public funds - if the local government changes hands in an election. We posit that such effects are most likely to be found in provinces that actually changed hands between political parties during the sample period. We therefore re-estimate Equation 2 after dropping these provinces. Figure B.14, panel A, shows that state-bank lending continues to suffer in the immediate quarters before an election in opposition provinces, but the relative increase in politically aligned provinces that we observed earlier is no longer there. When we replicate the analysis with yearly data in panel $\mathrm{B}$, we find that both the negative effect in opposition provinces and the positive effect in aligned provinces documented earlier remain. These results suggest that while expected rewards may partly explain why state-bank lending goes up relatively more in aligned provinces, expected punishments do not explain why it goes down in non-aligned provinces. 


\section{How does political lending affect economic outcomes?}

\subsection{Evidence from administrative data}

We now test whether the state-bank lending cycle induced by local elections translates into real outcomes. If it does, then politically contested provinces with an opposition mayor are expected to suffer from lower economic activity, while those with a politically aligned mayor are expected to see a boost in economic activity around local elections. Furthermore, if the real effects are indeed driven by politically induced lending, then they should be strongest in industries where state banks play a more important role relative to private banks.

To identify the real effects of politically induced lending, we draw on a new administrative dataset covering the period 2006-2016 introduced in Section 3. Recall that the underlying data are sourced from balance sheets and income statements by all corporates liable to pay tax, capturing the universe of formal activity. Our baseline estimates are based on manufacturing industries in line with previous literature, which has typically argued that manufacturing jobs are especially salient to voters (Bertrand et al., 2018). We show below that our results extend to other sectors of the economy and also confirm that voters indeed respond most to employment changes in manufacturing.

Consider the following DDD model:

$$
\begin{aligned}
& \text { LogOutcome }_{i, p, t}=\beta_{\tau} \text { Comp }_{p, t} \times \text { StateBankShare }_{i} \times \text { Election }_{t+\tau} \\
& +\alpha_{1} \text { Comp }_{p, t} \times \text { StateBankShare }_{i}+\alpha_{2} \text { StateBankShare }_{i} \times \text { Election }_{t+\tau} \\
& \quad+\alpha_{3} \text { Comp }_{p, t} \times \text { Election }_{t+\tau}+\alpha_{4} \text { Comp }_{p, t}+\theta_{i}+\gamma_{p}+\lambda_{t}+\varepsilon_{i, p, t}
\end{aligned}
$$

where LogOutcome $i, t$, is an economic outcome for industry $i$, province $p$, and time t. Compp, is the political contestedness variable created earlier and StateBankShare 
measures the share of state banks in total lending by industry nationally. We construct StateBankShare $i$ as an industry-level measure that does not vary with time and measure it as of the fourth quarter of 2005 to prevent possible reverse causality. ${ }^{40}$ As such, the main coefficient of interest, $\beta_{\tau}$, captures how economic outcomes in industries with an initially higher share of state bank lending and located in politically contested provinces move with the election cycle. We estimate Equation (6) separately for politically aligned and non-aligned provinces. If politically induced lending affects economic outcomes, then $\beta_{\tau}$ should be positive in the former group and negative in the latter group.

This research design is based on two premises. First, state banks systematically adjust their local lending behaviour around elections depending on the political alignment of the incumbent mayor. Second, the national market share of state banks varies considerably across industries. Identification then exploits the heterogeneity in industries' exposure to state banks under the assumption that firms can only imperfectly substitute for a change in credit supply from their main bank. ${ }^{41}$ This assumption implies that politically induced lending affects real economic outcomes to the extent that firms in the opposition provinces suffer aggregate financial constraints and firms in allied provinces see their constraints relax. In other words, if firms are able to perfectly switch between state and

\footnotetext{
${ }^{40}$ Note that StateBankShare is measured at the national, and not province, level. It is possible that banks and industries sort into a certain province, which would affect the market share of banks in that particular province. Unobserved shocks to industries could then affect demand for loans in that province. We use the industry market share of banks at the national level to reduce concerns that may arise from sorting. If there are industry-specific shocks that coincide with local elections, these should affect all provinces equally and regardless of political alignment.

${ }^{41}$ A rich literature has documented the stickiness of firm-bank relationships and how firms' access to credit suffers in the face of shocks to their relationship lenders, especially in the case of small business lending. See, for instance, Greenstone et al. (2014) and references therein.
} 
private banks - e.g., there are competitive spillovers between banks - then firms in opposition areas need not experience financial constraints.

This is an assumption that we can test directly in the data. We estimate Equation (6) with (log) total bank debt as our first dependent variable. Table 5 shows estimates for $\beta_{\tau}$ when $\tau=0$ (i.e. in the year before a local election) for politically aligned provinces in columns (1)-(4) and non-aligned provinces in columns (5)(8). We present estimates that control for alternative sets of fixed effects. There is strong evidence that industries with a high share of state bank lending located in politically contested provinces experience a reduction in total corporate borrowing if the incumbent mayor is from an opposition party. We find the opposite if the incumbent mayor is politically aligned, but these estimates are not statistically significant. Figure 8 presents results for the full election cycle, which control for province time trends. It shows that politically induced lending creates aggregate financial constraints for many businesses in non-aligned provinces, and likely relaxes them in aligned provinces, especially in the run up to local elections.

Data allow us to dig deeper into how corporate borrowing is affected by the political lending cycle. In Appendix C, we present estimates when the outcome of interest is short- term or long-term bank debt (Figure C.1). While we observe the cycle in both types of corporate borrowing, estimates show that the increase in aligned provinces and the decrease in non-aligned provinces are more pronounced in long-term corporate borrowing. As loans with longer maturities are typically used for capital investment purposes in Turkey, and those with shorter maturities for working capital purposes, the electoral cycle is likely to affect economic outcomes through an investment channel. 
Tables 6 and 7 show results when $\tau=0$ for employment and net sales, respectively. We find that employment and sales are higher in the run up to local elections in industries with a higher state bank share of total lending and located in politically aligned provinces. However, these estimates are not precisely estimated. In contrast, we find a highly significant and negative impact on both employment and sales for industries located in opposition provinces. These results hold across specifications with province time trends or a full set of province-time and industry-time fixed effects. Controlling for these fixed effects, Column (8) in Table 6 indicates that a 5 percentage point increase in the share of state banks in an industry would be associated with a $14 \%$ drop in industry employment before a local election in opposition provinces. The corresponding drop in net sales, according to the same specification in Table 7, would be $11 \%$.

Figure 9 shows estimates for the full election cycle. Panel A shows that the negative impact on employment in non-aligned provinces is already discernible one year ahead of a local election, though small in size. However, the positive impact on employment in politically aligned provinces is visible only in the year ahead of a local election. Panel B shows a similar trend for sales. These results show that politically induced credit constraints have sizable negative effects on the real economy when local governments do not belong to the same party as the central government.

We report additional results in Appendix C. The above estimates are based on a sample of manufacturing industries in metropolitan provinces. Tables C.1-C.2 and Figure C.2 extend our results to all sectors of the economy. The negative impact on employment and net sales for all sectors are smaller than for the manufacturing sample, but they continue to be statistically significant for nonaligned provinces in the run up to an election. In these regions, a 5 percentage 
point increase in the share of state banks is now associated with a $3.8 \%$ drop in industry employment and 3.2\% in industry net sales. Figure C.3 replicates these findings when we extend the sample to include all provinces and manufacturing industries. Figure C.4 replicates them for total assets in the top panel, but does not reveal a similar cycle for the number of enterprises in operation in the bottom panel. This suggests that political cycles affect real economic outcomes primarily through their impact on existing businesses rather than on firm entry or exit.

\subsection{Evidence on efficiency \& misallocation}

There is increasing evidence that reallocation of resources from low to high productivity users is an important source of growth. For instance, Larrain and Stumpner (2017) show that capital account liberalisation in Eastern Europe increased aggregate productivity through relieving firm-level financial constraints and a more efficient allocation of capital across firms. Bai et al. (2017) document that state-level banking deregulation led to large gains in industry productivity in the U.S. through the reallocation of labour. In this sub-section, we ask whether the electoral cycle leads to a misallocation of financial resources in Turkey. If politically induced lending redistributes resources from more to less productive users, then it can lead to a reduction in aggregate industry productivity.

Consider the following model:

$$
\Delta \text { LogCredit }_{i, p, t}=\beta_{\tau} \text { Eff iciency }_{i, p} \times \text { Election }_{t+\tau}+\alpha_{1} \text { Eff iciency }_{i, p}+\theta_{i}+\gamma_{p}+\lambda_{t}+\varepsilon_{i, p, t}
$$

where $\Delta \log C r e d i t_{i, p, t}=\log C r e d i t_{i, p, t}-\operatorname{LogCredit}_{i, t-1}$ captures the year-on-year growth rate of total bank credit that appear on the balance sheets of all firms 
located in province $p$ and operating in industry $i$. We proxy aggregate industry productivity by the asset turnover rate, which captures the efficiency with which an industry uses its capital to generate sales. For each province and industry pair, we define: Efficiency $p_{p, i}=$ NetSales $p, /$ TotalAssets $p, i$ using the beginning-of-sample information from 2006. This ensures that our efficiency measure is independent of future credit trends in the sample period. Industry fixed effects in (7) account for the fact that some industries naturally require a greater amount of assets to generate each dollar of sales. Province and year fixed effects capture unobservable factors at the local level and aggregate shocks at the national level. Note that we also control for initial levels of efficiency. The coefficient $\beta$ then identifies how credit growth at the industry-province level varies with initial productivity over the election cycle.

Table 8 shows results from this exercise across different specifications when $\tau=$ 0. Columns (1)-(3) indicate that industry-province pairs with greater initial efficiency typically experience greater credit growth during the sample period, unless there are upcoming local elections. The negative coefficient on the interaction term is sufficiently larger in ab- solute size than the positive coefficient on initial efficiency, so that industry-province pairs that are initially less productive experience greater credit growth in the run up to local elections. This result holds, and is typically more precisely estimated, with a full set of province-time and industry-time fixed effects included. It points at strong evidence that the political lending cycle identified earlier leads to a considerable misallocation of aggregate bank credit.

We replicate this exercise for the sample of politically aligned provinces in columns (4)-(6) and non-aligned provinces in columns (7)-(9). We find similar patterns in both samples, but estimates are more precise for non-aligned 
provinces. Politically induced financial misallocation appears stronger in these regions, where it likely distorts aggregate efficiency more than in aligned provinces. It is possible that such misallocation is not concentrated around local elections in aligned provinces, if state banks favour these regions in non-election years as well due to the central government's constant patronage of its strongholds.

We extend our estimates of Equation (7) to the full election cycle in Figure 10. Panel A shows estimates of $\beta_{\tau}$ from the sample of metropolitan provinces and panel B from all provinces with specifications including province-time fixed effects. Stripping local time-varying shocks in this way, we do not find much evidence for misallocation of credit in non-election years. We find that misallocation during election years is especially pronounced for non-aligned provinces in both panels. In light of earlier findings, this suggests that provinceindustry pairs that are initially more efficient are also those experiencing the largest increases in aggregate credit constraints in these regions. As they respond to these constraints by cutting down on employment growth, the impact on industry efficiency and productive jobs is expected to be substantially negative, and possibly long-lasting.

\subsection{Do jobs affect elections?}

In this sub-section, we check whether voters judge incumbent mayors based on local economic conditions in the run up to local elections. We focus on the role played by employment in particular, as a rich literature documents a strong correlation between changes in employment, especially in manufacturing, and the votes going to the incumbent party (Bertrand et al., 2018). If there is no such correlation, then it would not be in the interests of politicians to direct bank credit towards or away from manufacturing firms that affect job creation the most. 
Results of this exercise with alternative specifications are in Table 9. We regress the change in the vote share won by an incumbent party between the current and previous local elections on manufacturing employment growth in the past one year in columns (1)-(5). ${ }^{42}$ We find a strong correlation despite an admittedly small sample size. Controlling for election and province fixed effects, a $10 \%$ growth in total employment at the province level is associated with a 5.1 percentage point increase in the vote share of an incumbent party in metropolitan provinces. This estimate is lower at 1 percentage point increase in the sample of all provinces, which explains why tactical redistribution of credit can target metropolitan cities in particular.

We also confirm two long-standing arguments from the political economy literature. First, previous research argues that voters tend to forget events that occurred early on in the electoral cycle and attach greater weight to more recent economic developments (Rogoff and Sibert, 1988). In line with this myopic voter argument, we find that employment growth in the past two years before a local election has less explanatory power for incumbent parties' performance at the electoral box (columns (6)-(10) of Table 9). While there is still a strong and positive correlation, point estimates are around half of those in columns (1)-(5). Second, we replicate this exercise and show in Table C.3 of Appendix C that nonmanufacturing employment growth has minimal explanatory power for incumbent parties' electoral success. This complements evidence from earlier studies that policy makers target the manufacturing sector in particular, ostensibly for their job creation potential, to influence election outcomes.

\footnotetext{
${ }^{42}$ We calculate total manufacturing employment in each province by aggregating industry-level employment figures from the administrative data.
} 
As a final test of how important jobs are to re-election prospects for incumbent parties, we collect data from the national accounts compiled by the Turkish Statistical Institute. These accounts provide measures of GDP by province and major sectors over a period of 2004-2014. This allows us to relate changes in the manufacturing component of province- level GDP and test the myopic voter argument for a longer horizon. Results are in Table C.4. We find a positive correlation that increases in size when manufacturing GDP growth is measured closer to local elections. These estimates are not always precise, suggesting that job creation plays a much more prominent role than growth in value added to explain the re-election chances of incumbent parties.

\section{Conclusion}

In this paper, we test for the presence of politically motivated distribution of financial resources in Turkey using a dataset with detailed information on banking activity and local economic outcomes. Our dataset is novel along several dimensions and helps us achieve stronger identification than earlier studies, while shedding light on some of the theoretical arguments voiced in the literature. For instance, high frequency data allow us to pinpoint the effects of politically induced lending and differentiate between pre-election tactical redistribution and post-election rewards or punishment mechanisms.

Our main findings are two-fold. First, we show that state banks in Turkey engage in politically motivated lending around local elections when compared with private banks. This election-induced cycle is particularly salient in corporate loans in the run up to elections and it is targeted at politically competitive provinces based on their political alignment. In particular, state banks increase lending to the corporate sector relative to private banks in politically attractive 
provinces when an incumbent mayor is aligned with the ruling party, while they reduce it if the incumbent mayor is from an opposition party. In aggregate, lending by state banks is lower prior to elections compared with private banks, which constitutes a first piece of evidence that political involvement in bank lending leads to a drop in access to credit.

Second, we show that this redistribution of credit has real consequences as it leads to a significant reduction in local economic activity in opposition provinces that are politically contested. Specifically, firms located in such provinces become credit constrained due to the reduction in state bank lending and respond by reducing employment and sales. It is crucial to understand the distributive implications of political lending to inform policies about circumscribing the latitude of governments to intervene in the economy (Cole, 2009). Our results suggest that aggregate credit constraints affect the relatively more efficient province- industry pairs in politically contested areas, which shed jobs in return. This shows that politically induced lending distorts the efficient allocation of credit and potentially reduces aggregate productivity in these areas, coming at a great cost to local economies.

Our findings support theories of tactical redistribution to manipulate voters for re-election prospects. Rolling estimations in non-election years show some evidence that the central government may have resorted to patronage when it did not have election concerns. We document suggestive evidence that the tactical reallocation of bank credit, via its impact on jobs, helps the central government increase the electoral success of its allied mayoral candidates and decrease that of opponents. This provides one of the first pieces of evidence on how voters can be manipulated via the distortion of financial intermediaries. Future research should explore how such distortions and governments' role in financial misallocation can be minimised. 


\section{References}

Acemoglu, D. and M. Ucer (2015). The ups and downs of Turkish growth, 20022015: Political dynamics, the European Union and the institutional slide. NBER Working Paper No. 21608.

Akey, P., R. Heimer, and S. Lewellen (2017). Politicizing consumer credit. Technical report. Akhmedov, A. and E. Zhuravskaya (2004). Opportunistic political cycles: Test in a young democracy setting. The Quarterly Journal of Economics 119(4), 1301-1338.

Angrist, J. D. and J.-S. Pischke (2009). Mostly harmless econometrics: An empiricist's companion. Princeton University Press.

Bai, J. J., D. Carvalho, and G. M. Phillips (2017). The impact of bank credit on labor reallocation and aggregate industry productivity. Technical report, National Bureau of Economic Research.

Baum, C. F., M. Caglayan, and O. Talavera (2010). Parliamentary election cycles and the Turkish banking sector. Journal of Banking \& Finance 34 (11), 27092719.

Bertrand, M., F. Kramarz, A. Schoar, and D. Thesmar (2018, May). The cost of political connections. Review of Finance 22(3), 849-876.

Brender, A. and A. Drazen (2005). Political budget cycles in new versus established democracies. Journal of Monetary Economics 52 (7), 1271-1295.

Brender, A. and A. Drazen (2008). How do budget deficits and economic growth affect reelection prospects? Evidence from a large panel of countries. The American Economic Review 98(5), 2203-2220.

Brollo, F. and T. Nannicini (2012). Tying your enemy's hands in close races: the politics of federal transfers in Brazil. American Political Science Review 106 (04), 742-761.

Carvalho, D. (2014). The real effects of government-owned banks: Evidence from an emerging market. The Journal of Finance 69 (2), 577-609.

Chavaz, M. and A. K. Rose (2018). Political borders and bank lending in postcrisis America. Review of Finance, rfy027. 
Cole, S. (2009). Fixing market failures or fixing elections? Agricultural credit in India. American Economic Journal: Applied Economics 1 (1), 219-250.

Cox, G. W. and M. D. McCubbins (1986). Electoral politics as a redistributive game. The Journal of Politics 48(2), 370-389.

Di Maggio, M., A. Kermani, R. Ramcharan, and E. G. Yu (2017). Household credit and local economic uncertainty.

Dinç, I. S. (2005). Politicians and banks: Political influences on governmentowned banks in emerging markets. Journal of Financial Economics 77 (2), 453-479.

Dixit, A. and J. Londregan (1996). The determinants of success of special interests in redistributive politics. The Journal of Politics 58(4), 1132-1155.

Englmaier, F. and T. Stowasser (2017). Electoral cycles in savings bank lending. Journal of the European Economic Association 15(2), 296-354.

Greenstone, M., A. Mas, and H.-L. Nguyen (2014). Do credit market shocks affect the real economy? quasi-experimental evidence from the great recession and normal economic times. Technical report, National Bureau of Economic Research.

Gulen, H. and M. Ion (2015). Policy uncertainty and corporate investment. The Review of Financial Studies 29(3), 523-564.

Healy, A. and G. S. Lenz (2014). Substituting the end for the whole: Why voters respond primarily to the election-year economy. American Journal of Political Science 58(1), 31-47.

İncioğlu, N. (2002). Local elections and electoral behaviour. Politics, parties, and elections in Turkey, London, Lynne Rienner Publishers, 73-90.

Jens, C. E. (2017). Political uncertainty and investment: Causal evidence from US gubernatorial elections. Journal of Financial Economics 124 (3), 563-579.

Julio, B. and Y. Yook (2012). Political uncertainty and corporate investment cycles. The Journal of Finance 67(1), 45-83.

Khwaja, A. I. and A. Mian (2005). Do lenders favor politically connected firms? Rent provision in an emerging financial market. The Quarterly Journal of Economics 120(4), 1371-1411. 
La Porta, R., F. Lopez-de Silanes, and A. Shleifer (2002). Government ownership of banks. The Journal of Finance 57(1), 265-301.

Larrain, M. and S. Stumpner (2017). Capital account liberalization and aggregate productivity: The role of firm capital allocation. The Journal of Finance 72(4), 1825-1858.

Leuz, C. and F. Oberholzer-Gee (2006). Political relationships, global financing, and corporate transparency: Evidence from Indonesia. Journal of Financial Economics 81(2), 411-439.

MacRae, C. D. (1977). A political model of the business cycle. Journal of Political Economy 85(2), 239-263.

Nordhaus, W. D. (1975). The political business cycle. The Review of Economic Studies 42 (2), 169-190.

Önder, Z. and S. Özyıldırım (2013). Role of bank credit on local growth: Do politics and crisis matter? Journal of Financial Stability 9 (1), 13-25.

Peltzman, S. (1992). Voters as fiscal conservatives. The Quarterly Journal of Economics 107(2), 327-361.

Rogoff, K. and A. Sibert (1988). Elections and macroeconomic policy cycles. The Review of Economic Studies 55(1), 1-16.

Sapienza, P. (2004). The effects of government ownership on bank lending. Journal of Financial Economics 72(2), 357-384.

Sayarı, S. (2014). Interdisciplinary approaches to political clientelism and patronage in Turkey. Turkish Studies 15(4), 655-670.

Shi, M. and J. Svensson (2006). Political budget cycles: Do they differ across countries and why? Journal of Public Economics 90 (8), 1367-1389.

Shleifer, A. (1998). State versus private ownership. The Journal of Economic Perspectives 12(4), 133-150.

Shleifer, A. and R. W. Vishny (1994). Politicians and firms. The Quarterly Journal of Economics 109(4), 995-1025.

Stiglitz, J. E. (1993). The role of the state in financial markets. The World Bank Economic Review 7 (suppl. 1), 19-52. 


\section{Figures and Tables}

Figure 1: District-level political alignment in two non-metropolitan provinces

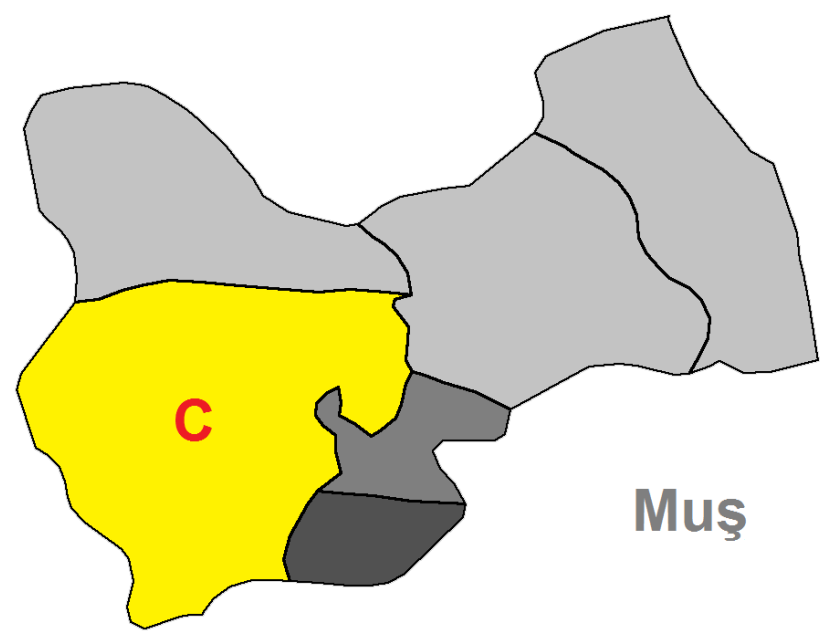

(a) A politically aligned province in 2004 elections

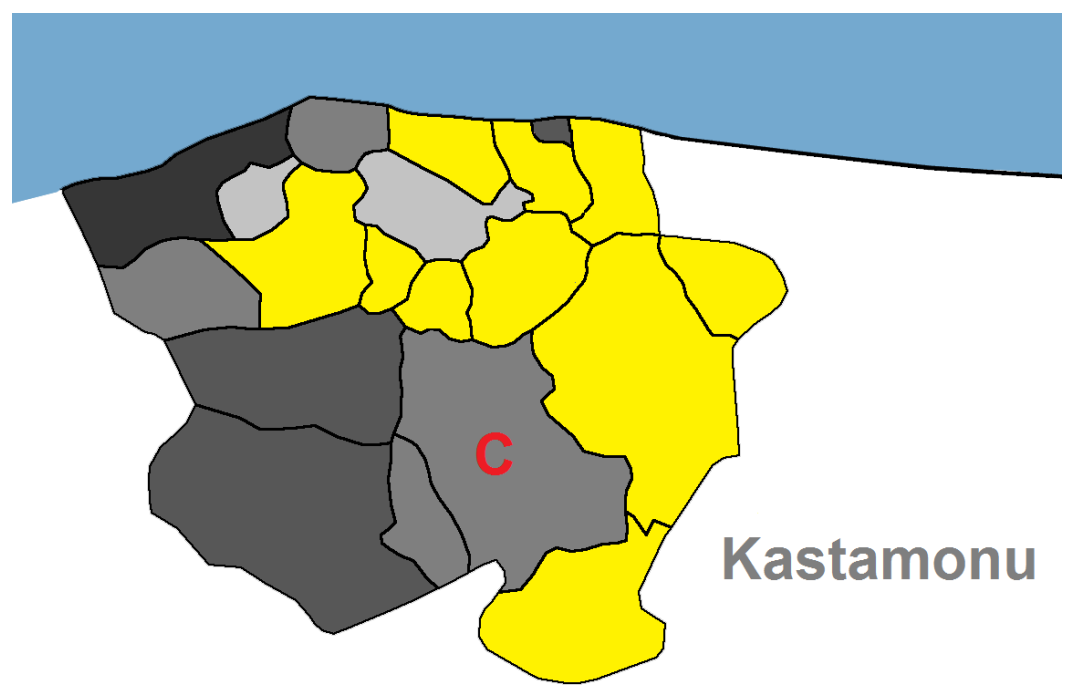

(b) A politically non-aligned province in 2004 elections

Notes: Panel A shows a province in which the elected central district mayor is aligned with the central government and Panel B shows a province in which the elected central district mayor is non-aligned. "C" in red colour stands for the central district. Politically aligned districts are given in yellow and non-aligned districts are given in varying shades of gray corresponding to different opposition parties. 
Figure 2: Political competition and alignment in metropolitan provinces

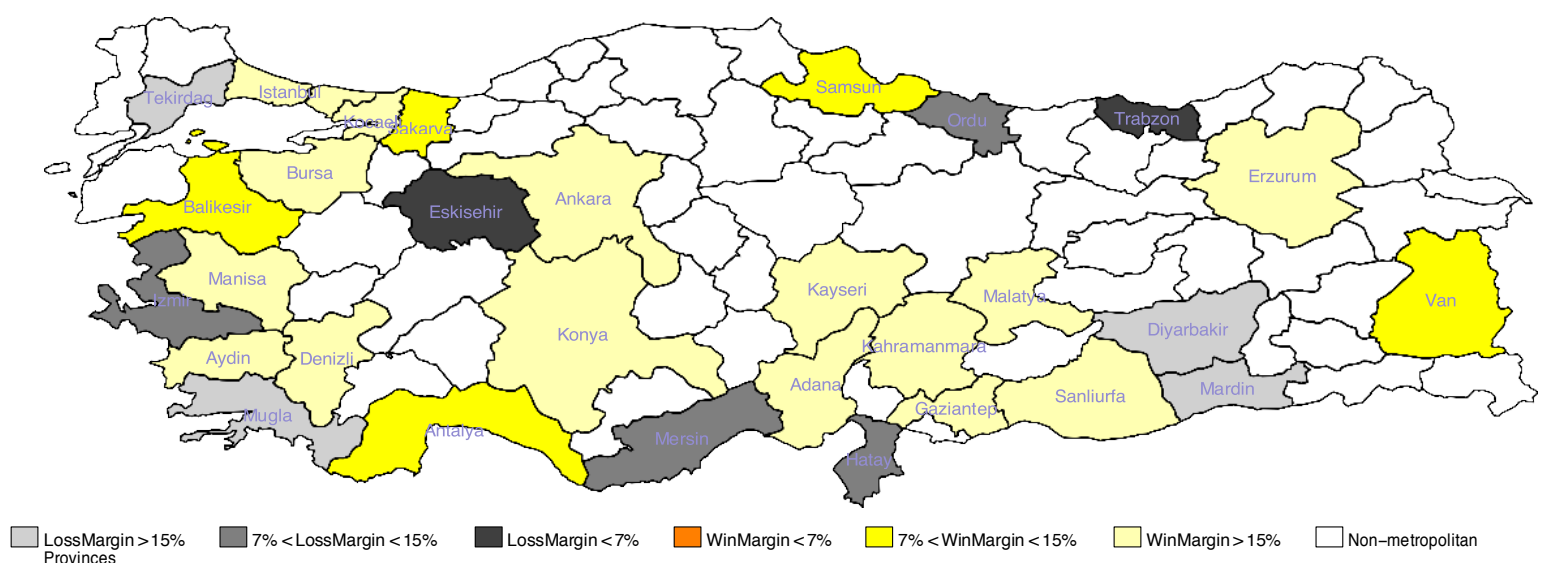

(a) 2004 local elections

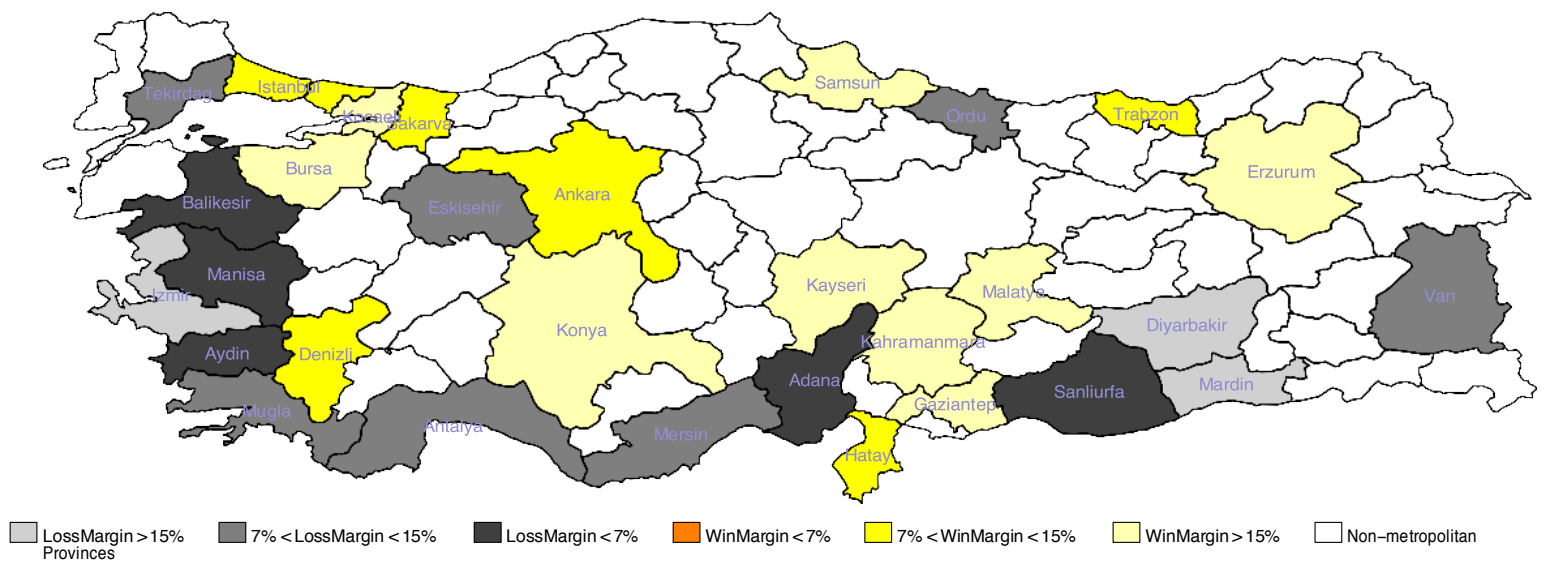

(b) 2009 local elections

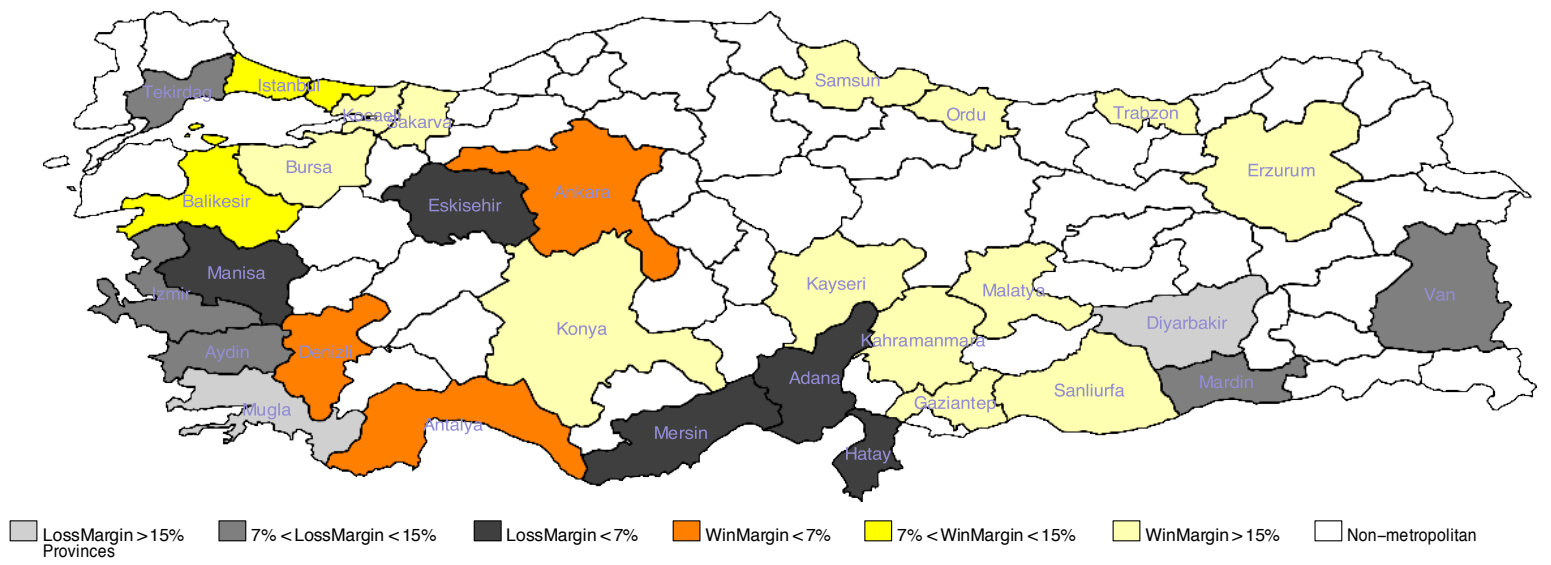

(c) 2014 local elections

Notes: Panels A, B, and C show the win/loss margins for the governing party in 2004, 2009, and 2014 local elections, respectively. Politically aligned provinces are in shades of yellow and non-aligned provinces are in shades of gray. 
Figure 3: Aggregate credit and banks' market shares, 2003-2017

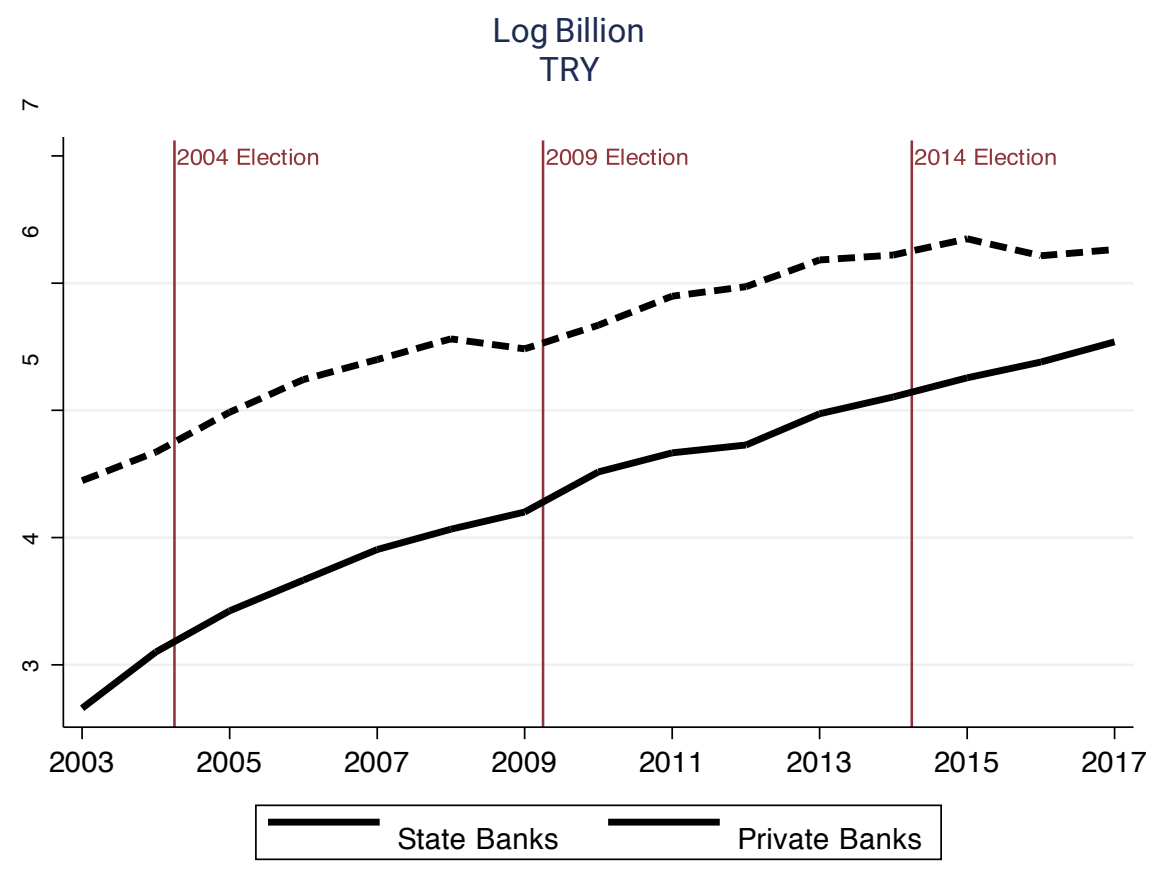

(a) Aggregate credit by bank type

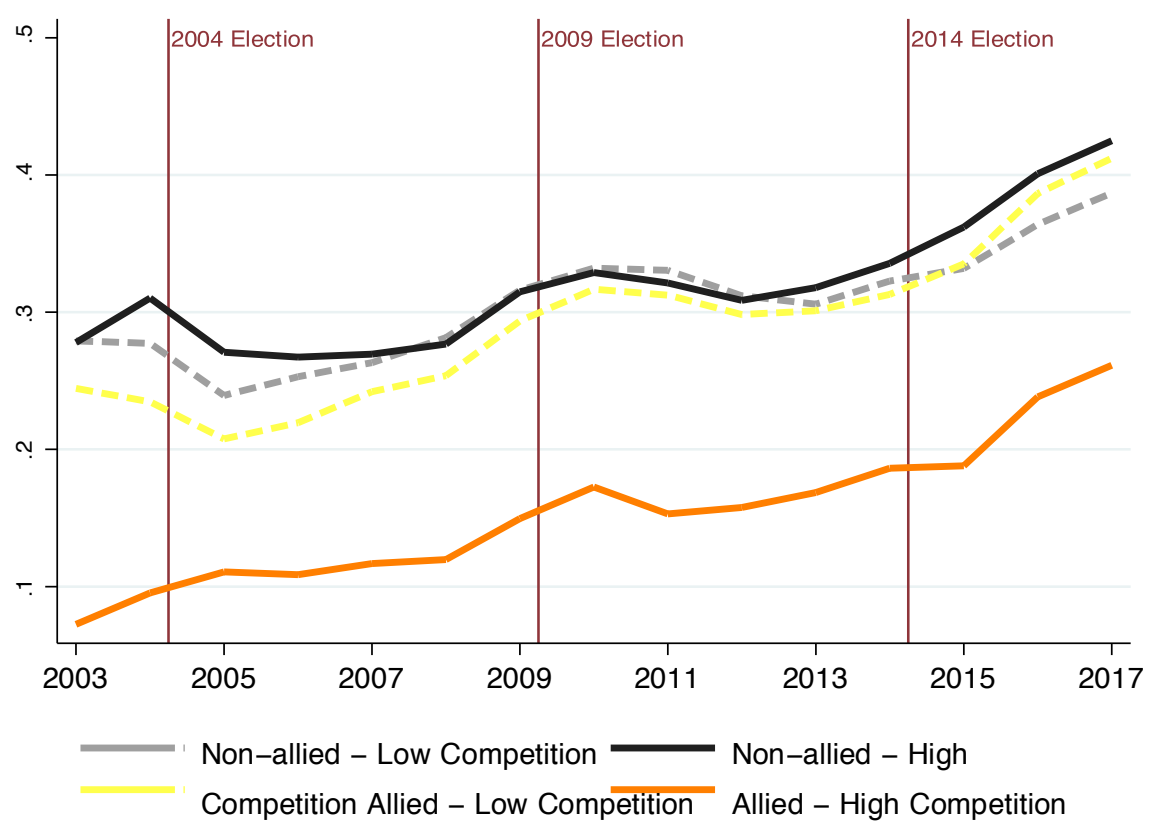

(b) Credit market share of state banks by political alignment and competition

Notes: Panel A shows the evolution of the stock of all cash loans extended by state-owned and private banks during the period 2003-2017. Panel B shows the evolution of the market share of state banks in total cash loans during the same period by political alignment and competition. Sample includes all provinces in panel A and metropolitan provinces in panel B. Politically aligned provinces are in shades of yellow and non-aligned provinces are in shades of gray in panel B. 
Figure 4: State bank lending relative to private banks over the election cycle

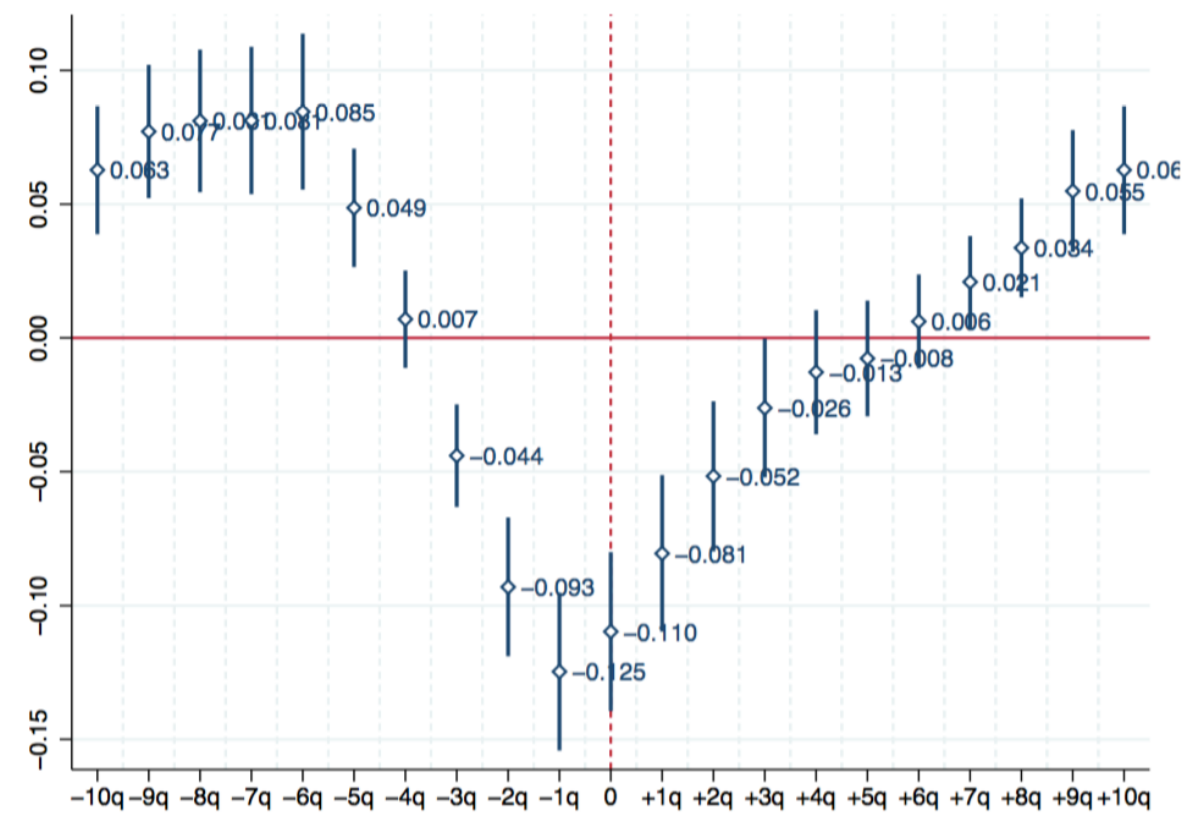

(a) Sample: Metropolitan provinces

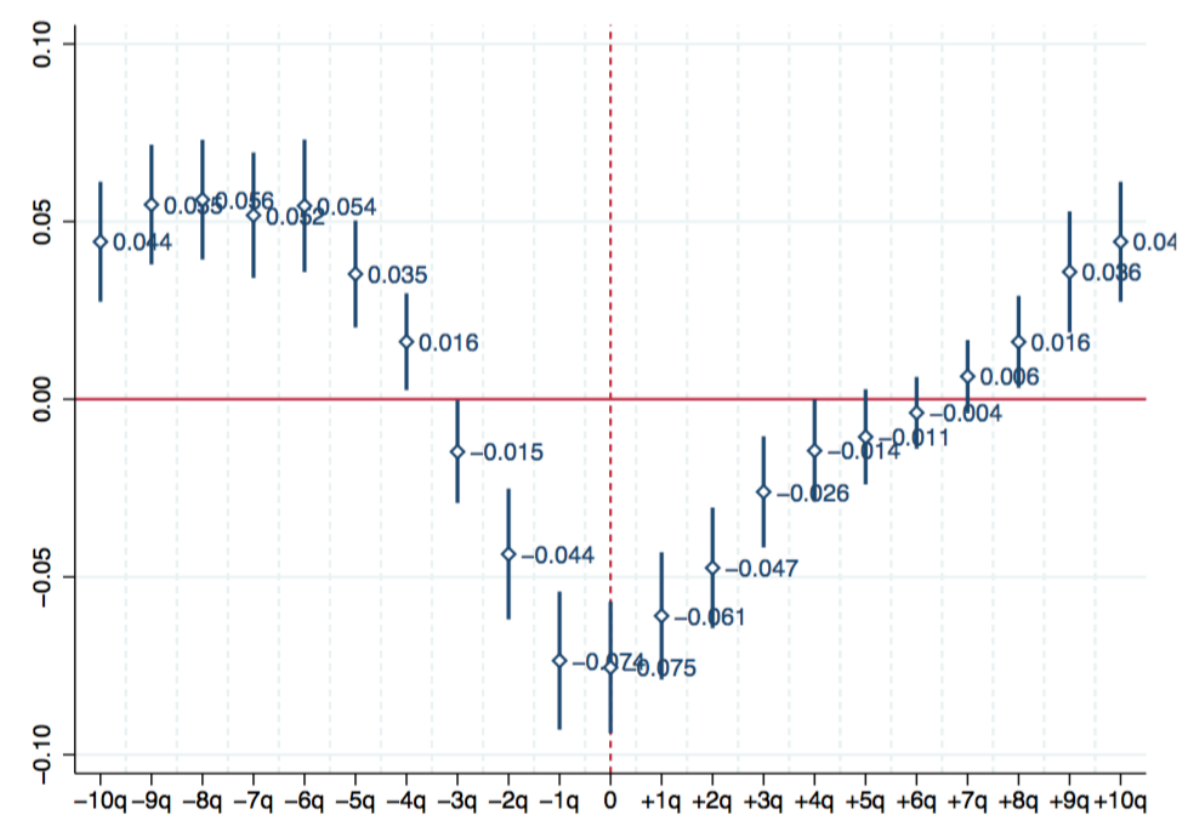

(b) Sample: All provinces

Notes: This figure shows results of equation (1) estimated on quarterly data (2007q4-2017q4) when $\tau$ takes values from -10 to +10 , indicating the number of quarters around elections. Each plotted coefficient comes from a single regression; bars around estimates show 90\% confidence intervals. Each regression controls for local branches, our baseline set of fixed effects, and province time trends. Panel A includes metropolitan provinces and panel B includes the full sample. 
Figure 5: Tactical redistribution of state bank lending over the election cycle
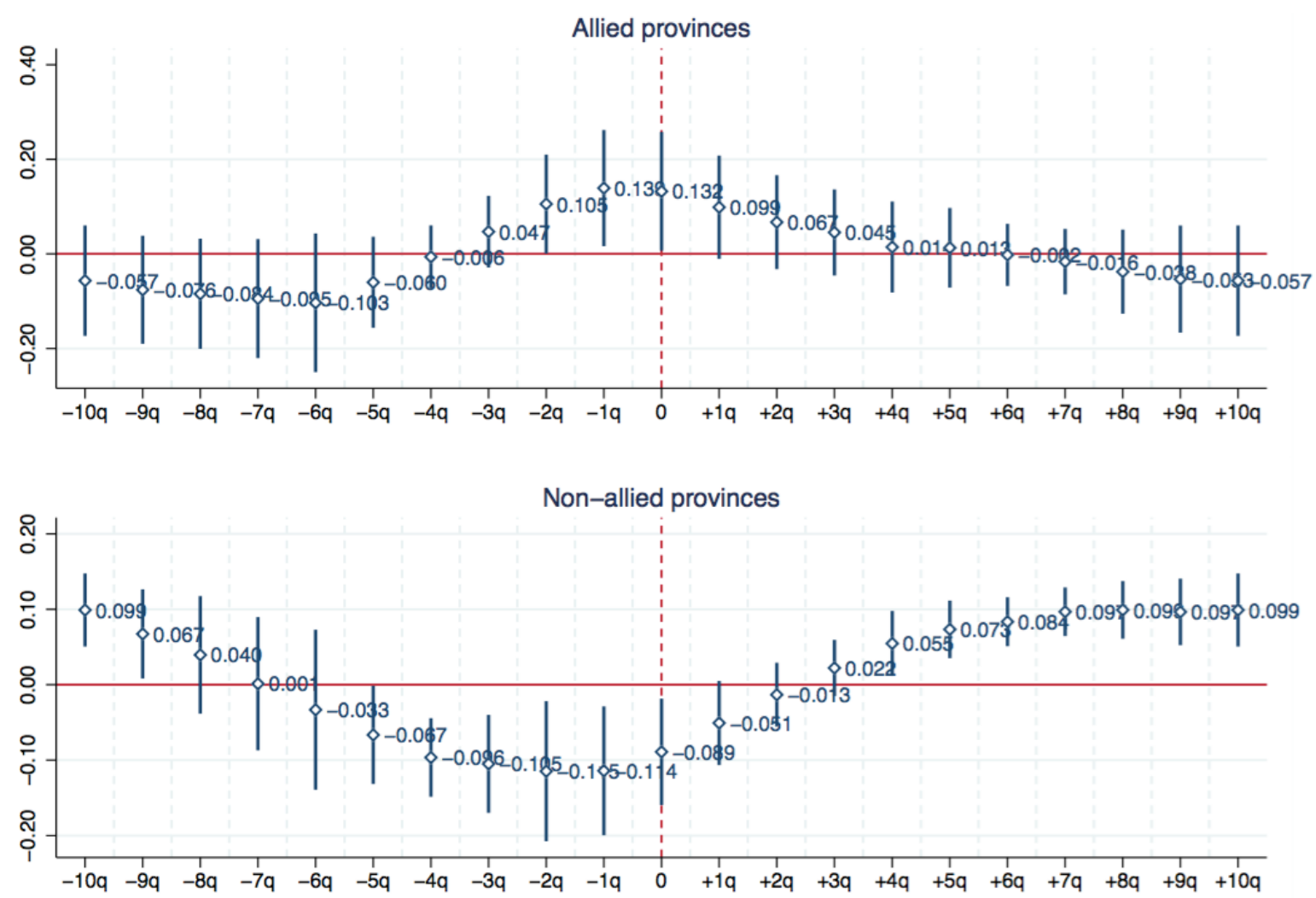

Notes: This figure shows results of equation (2) estimated on quarterly data (2007q4-2017q4) when $\tau$ takes values from -10 to +10 , indicating the number of quarters around elections. Sample includes metropolitan provinces. Each plotted coefficient comes from a single regression; bars around estimates show $90 \%$ confidence intervals. Each regression controls for local branches, our baseline set of fixed effects, and province time trends. Estimates are reported separately for aligned and non-aligned provinces in each panel. 
Figure 6: Corporate vs. consumer loans: Tactical redistribution of state-bank credit over the election cycle

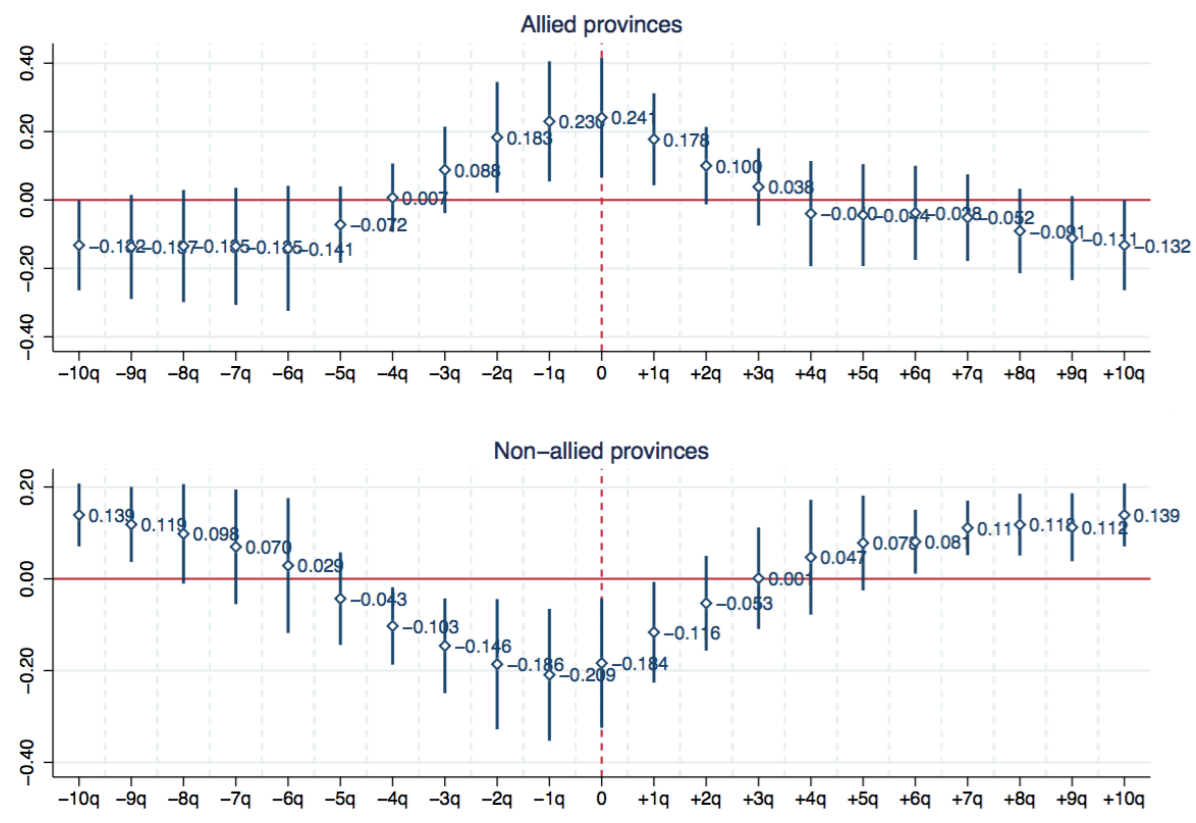

(a) Dependent variable: Corporate loans
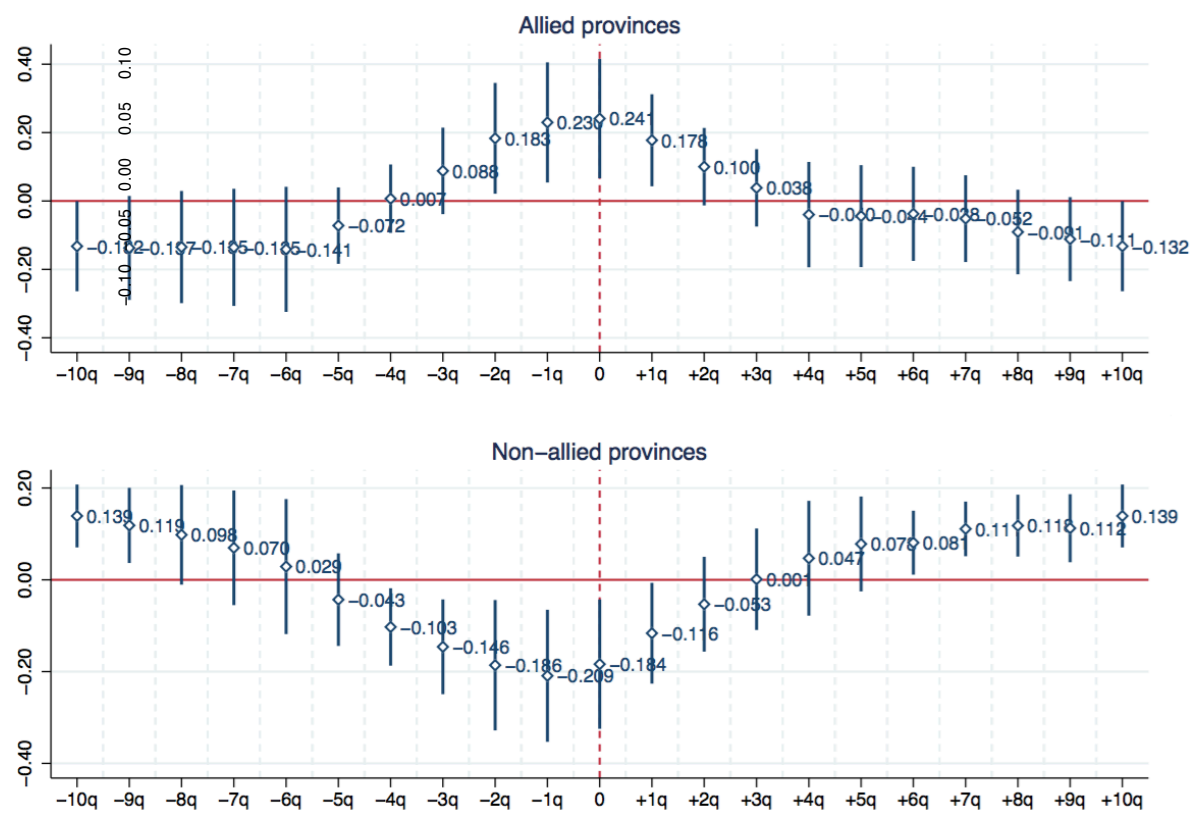

(b) Dependent variable: Consumer loans

Notes: This figure shows results of equation (2) estimated on quarterly data (2007q4-2017q4) when $\tau$ takes values from -10 to +10 , indicating the number of quarters around elections. Sample includes metropolitan provinces. Each plotted coefficient comes from a single regression; bars around estimates show $90 \%$ confidence intervals. Each regression controls for local branches, our baseline set of fixed effects, and province time trends. Panel A shows estimates for corporate loans and panel B shows estimates for consumer loans. Estimates are reported separately for aligned and non-aligned provinces in each panel. 
Figure 7: Share of non-performing corporate loans over the election cycle
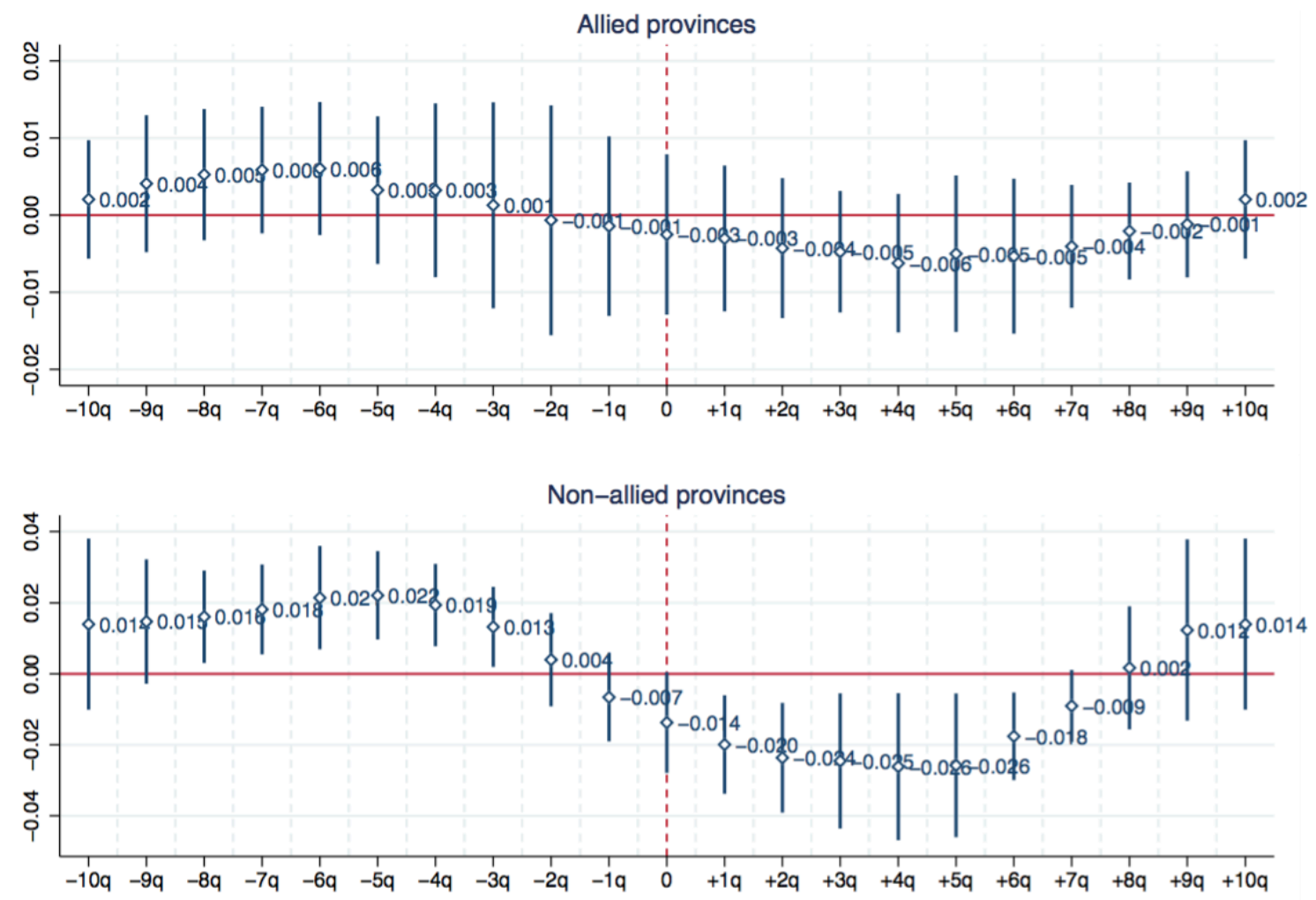

Notes: This figure shows results of equation (2) estimated on quarterly data (2007q4-2017q4) when $\tau$ takes values from -10 to +10 , indicating the number of quarters around elections. Sample includes metropolitan provinces. Each plotted coefficient comes from a single regression; bars around estimates show $90 \%$ confidence intervals. Each regression controls for local branches, our baseline set of fixed effects, and province time trends. Estimates are reported separately for aligned and non-aligned provinces in each panel. 
Figure 8: Effects of political lending on corporate borrowing in manufacturing
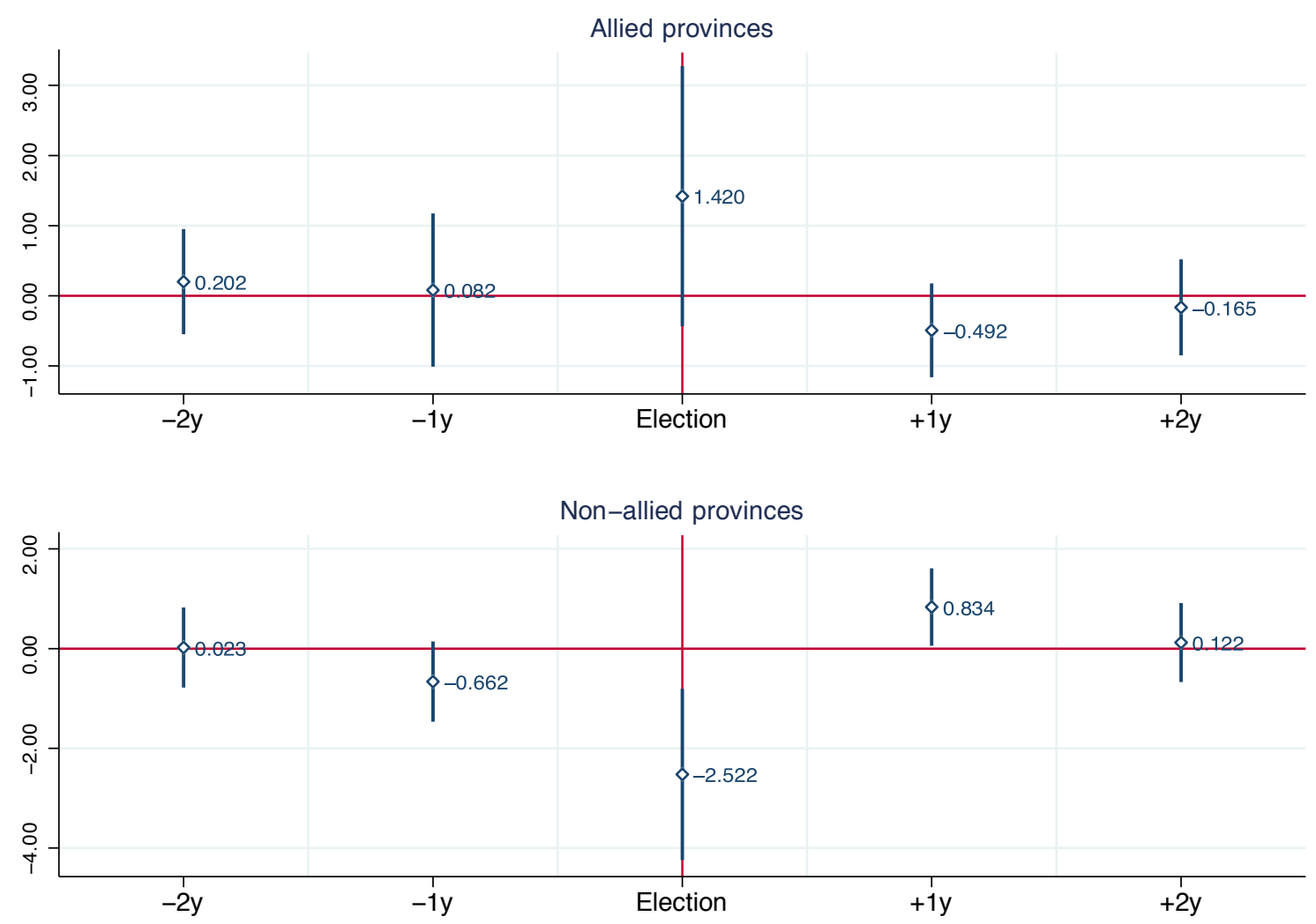

Notes: This figure shows results of equation (6) estimated on yearly data (2006-2016) when $\tau$ takes values from -2 to +2 , indicating the number of years around elections, for metropolitan provinces. Each plotted coefficient comes from a single regression; bars around estimates show $90 \%$ confidence intervals. Each regression controls for our baseline set of fixed effects and province time trends. Estimates are reported separately for aligned and non-aligned provinces in each panel. 
Figure 9: Effects of political lending on corporate activity in manufacturing
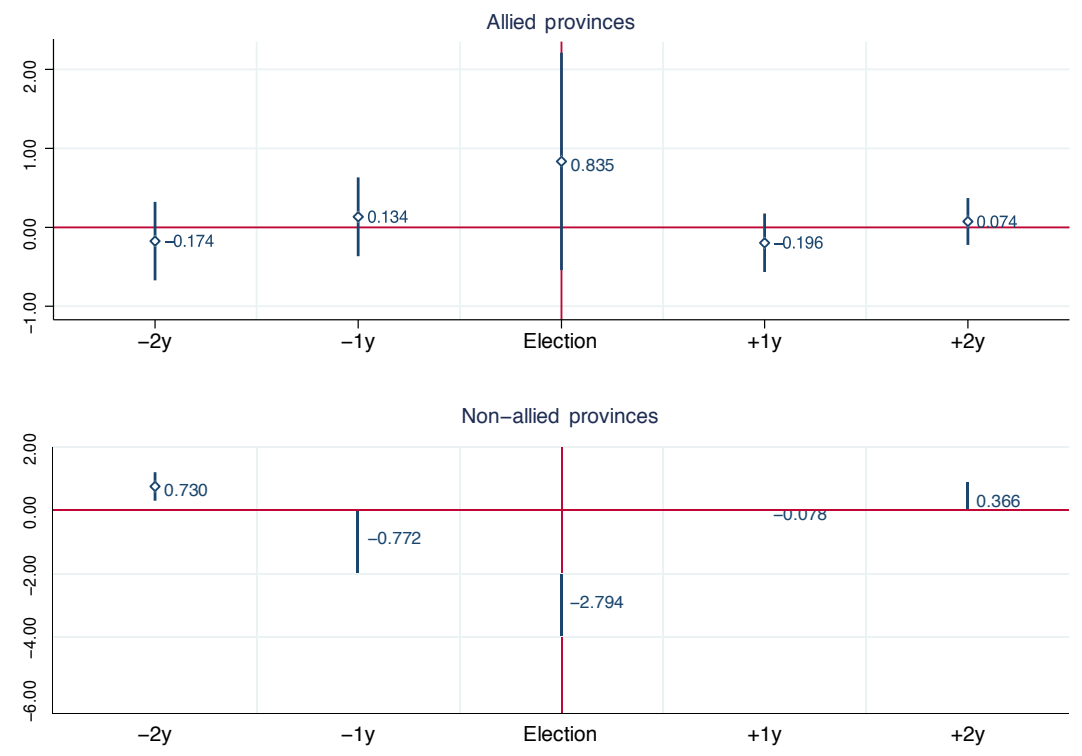

(a) Dependent variable: Employment
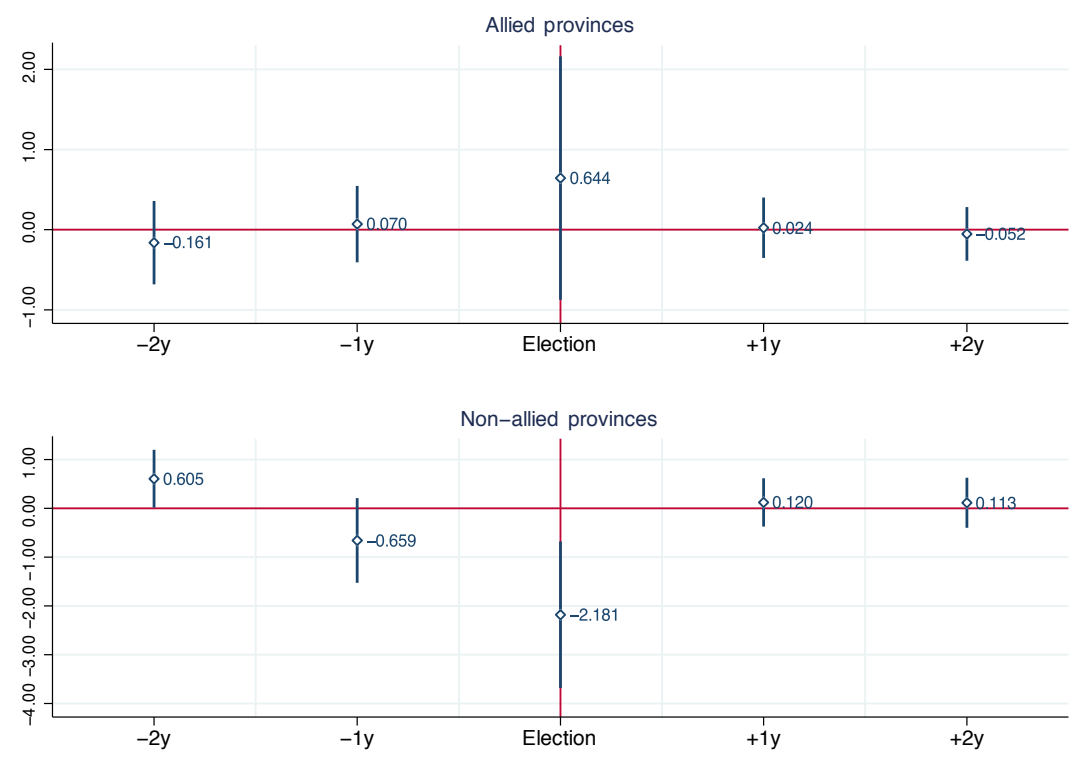

(b) Dependent variable: Net sales

Notes: This figure shows results of equation (6) estimated on yearly data (2006-2016) when $\tau$ takes values from -2 to +2 , indicating the number of years around elections, for metropolitan provinces. Each plotted coefficient comes from a single regression; bars around estimates show $90 \%$ confidence intervals. Each regression controls for a set of fixed effects and province time trends. Panel A shows estimates for employment and panel B shows estimates for net sales. Estimates are reported separately for aligned and non-aligned provinces in each panel. 
Figure 10: Electoral cycle in the allocation of bank credit by initial efficiency
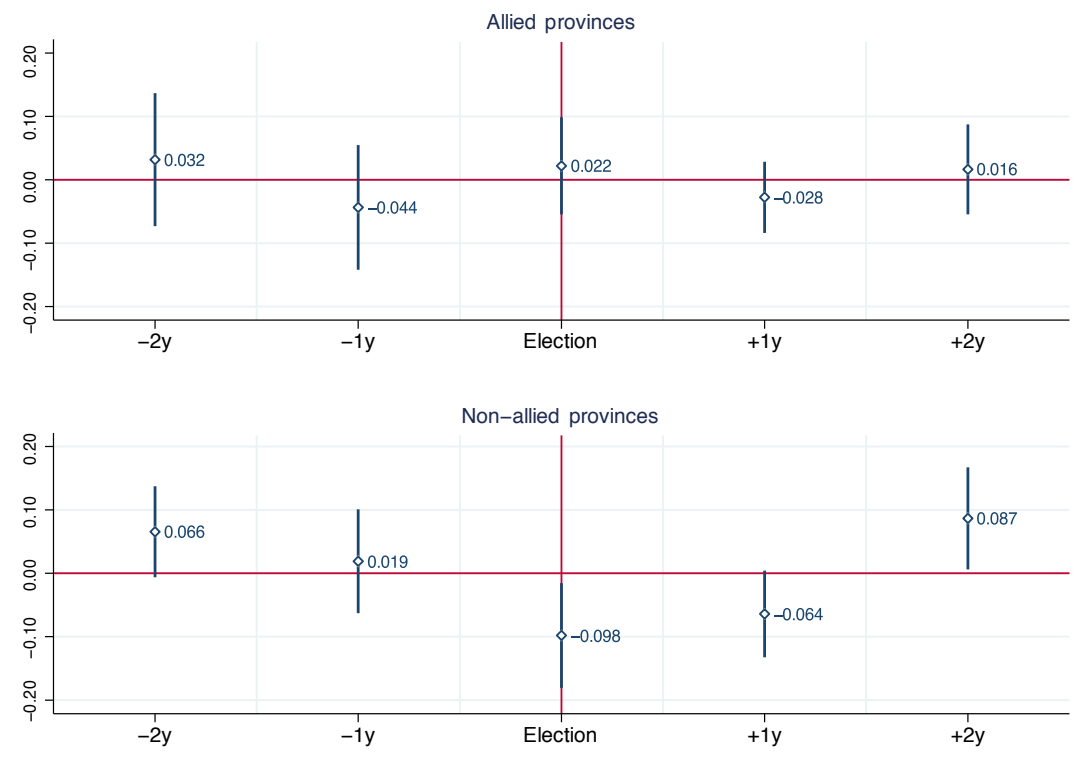

(a) Sample: Metropolitan provinces
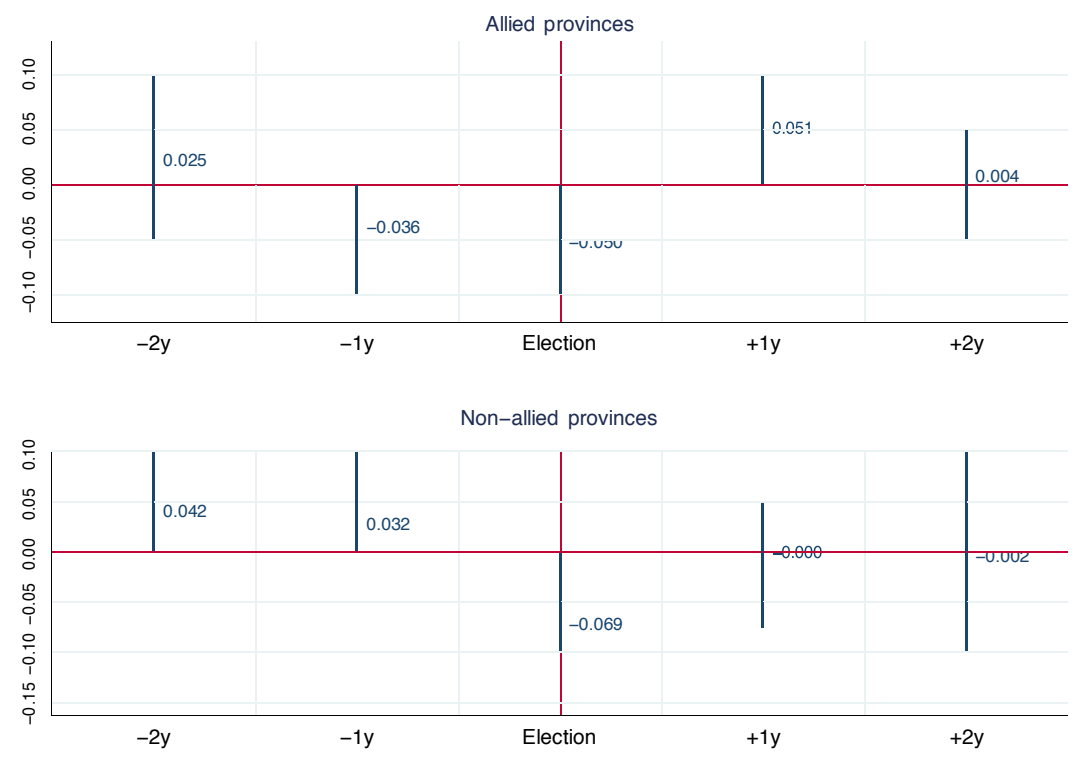

(b) Sample: All provinces

Notes: This figure shows results of equation (7) estimated on yearly data when $\tau$ takes values from -2 to +2 , indicating the number of years around elections. Each plotted coefficient comes from a single regression; bars around estimates show 90\% confidence intervals. Each regression controls for province-time and industry-time fixed effects. Panel A shows estimates for the sample of metropolitan provinces and panel B shows estimates for the sample of all provinces. Estimates are reported separately for aligned and non-aligned provinces in each panel. 
Table 1: Composition and performance of Turkish banks by ownership

\begin{tabular}{lcccc}
\hline & & 1999 & 2004 & 2015 \\
\hline Panel A: & & & & \\
Number of banks & Total & 54 & 34 & 33 \\
& State & 4 & 3 & 3 \\
& Private & 50 & 31 & 30 \\
& & & & \\
Number of branches & Total & 6,946 & 6,087 & 11,150 \\
& State & 2,865 & 2,149 & 3,681 \\
& Private & 4,081 & 3,938 & 7,469 \\
& & & & \\
Number of employees & Total & 152,578 & 122,227 & 195,613 \\
& State & 72,007 & 39,467 & 58,211 \\
& Private & 80,571 & 82,760 & 137,402 \\
& & & & \\
\hline Panel B: & & & & \\
NPLs / Loans & State & $10.0 \%$ & $11.1 \%$ & $2.7 \%$ \\
& Private & $3.6 \%$ & $4.9 \%$ & $3.3 \%$ \\
Return on Assets & & & & \\
& State & $1.1 \%$ & $2.5 \%$ & $1.4 \%$ \\
& Private & $4.5 \%$ & $1.6 \%$ & $1.0 \%$ \\
& & & & \\
& State & $4.1 \%$ & $9.4 \%$ & $10.1 \%$ \\
& Private & $12.9 \%$ & $15.8 \%$ & $11.0 \%$ \\
\hline \multirow{2}{*}{ Equity / Assets } & & & &
\end{tabular}

Notes: This table summarises the composition and financial performance of the banking sector in Turkey. State banks are defined as banks in which the central government has a controlling stake. Private banks are defined as all other banks. We exclude investment banks, development banks, and participation banks. NPLs denotes non-performing loans. 
Table 2: Summary statistics

\begin{tabular}{lccccccc}
\hline Variables & Mean & Median & S.D. & Min & Max & Obs. & Source \\
\hline Panel A: Quarterly cash loans & (2007q4-2017q4) & & & & & \\
log Total loans & 13.50 & 13.39 & 1.40 & 9.24 & 19.28 & 6,642 & FinTürk \\
log Corporate loans & 12.23 & 12.15 & 1.61 & 7.16 & 18.58 & 6,642 & FinTürk \\
$\log$ Consumer loans & 12.61 & 12.54 & 1.28 & 8.67 & 17.69 & 6,642 & FinTürk \\
$\log$ Non-performing loans & 10.03 & 9.94 & 1.51 & 4.37 & 15.67 & 6,642 & FinTürk \\
$\log$ State bank loans & 13.40 & 13.28 & 1.20 & 10.62 & 18.36 & 3,321 & FinTürk \\
$\log$ Private bank loans & 13.59 & 13.54 & 1.57 & 9.24 & 19.28 & 3,321 & FinTürk \\
$\log$ State non-performing loans & 9.76 & 9.59 & 1.26 & 5.94 & 14.33 & 3,321 & FinTürk \\
$\log$ Private non-performing loans & 10.31 & 10.33 & 1.69 & 4.37 & 15.67 & 3,321 & FinTürk
\end{tabular}

Panel B: Election data

$\begin{array}{llllllll}\text { Aligned (dummy) } & 0.60 & 1.00 & 0.49 & 0.00 & 1.00 & 243 & \text { TurkStat } \\ \text { Competition } & 0.82 & 0.85 & 0.15 & 0.24 & 0.99 & 243 & \text { TurkStat }\end{array}$

Panel C: Annual economic data (2006-2016)

\begin{tabular}{lccccccc}
$\log$ Number of establishments & 3.85 & 3.71 & 1.48 & 0.00 & 9.96 & 9,785 & MoI \\
$\log$ Bank debt & 16.91 & 16.95 & 2.40 & 8.11 & 23.14 & 7,646 & MoI \\
$\log$ Employment & 6.22 & 6.17 & 1.98 & 0.00 & 12.77 & 9,785 & MoI \\
$\log$ Net sales & 18.16 & 18.07 & 2.27 & 12.03 & 24.85 & 9,677 & MoI \\
$\log$ Total assets & 18.75 & 18.68 & 2.03 & 13.65 & 24.80 & 7,972 & MoI \\
\hline
\end{tabular}

Notes: This table presents summary statistics for the main variables in our analysis. All variables are in logs except in Panel B. Aligned indicates whether a province is ruled at the time by a mayor from the ruling party or not. Competition is defined as 1 minus the win margin. MoI stands for Ministry of Industry. 


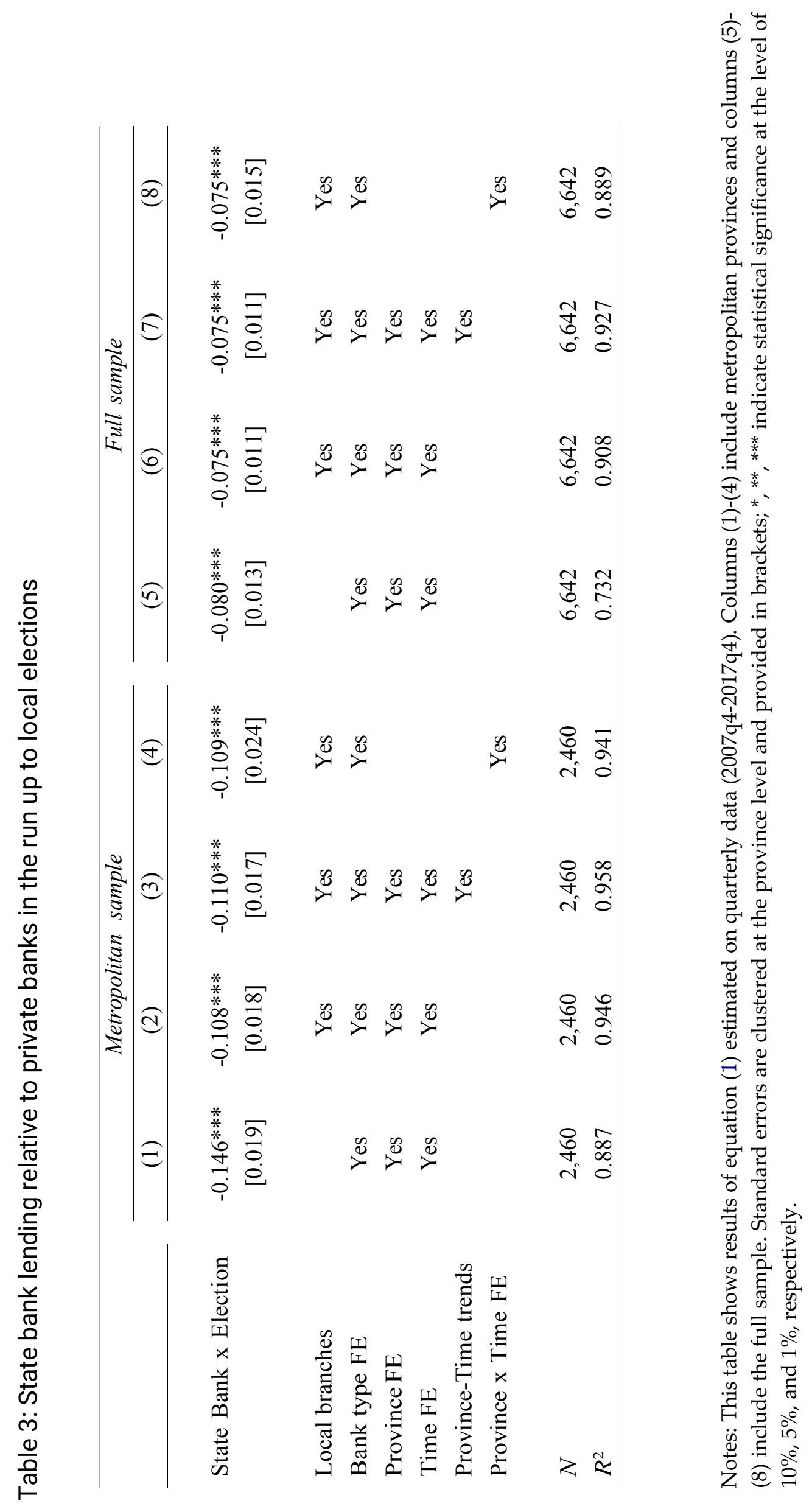




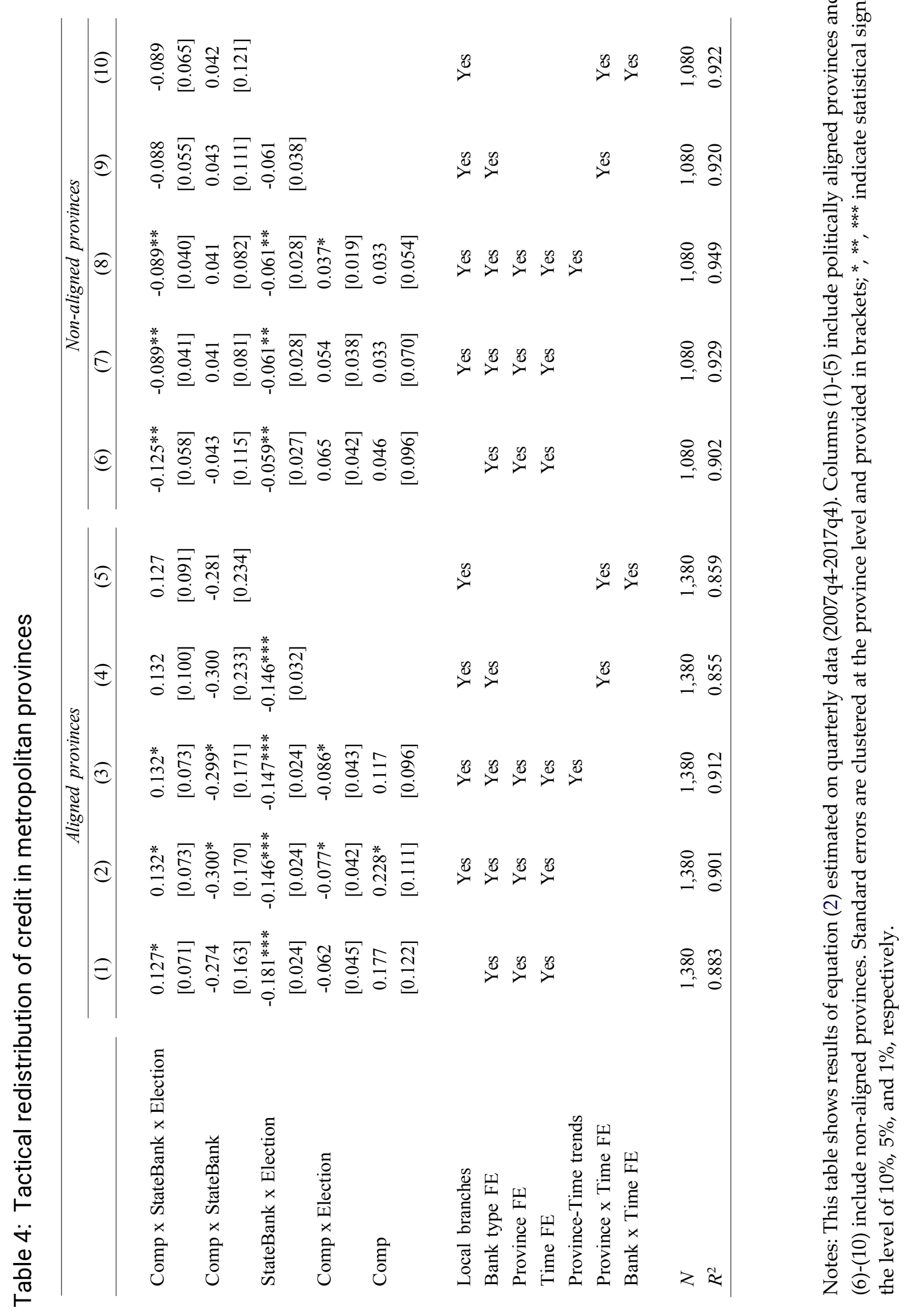




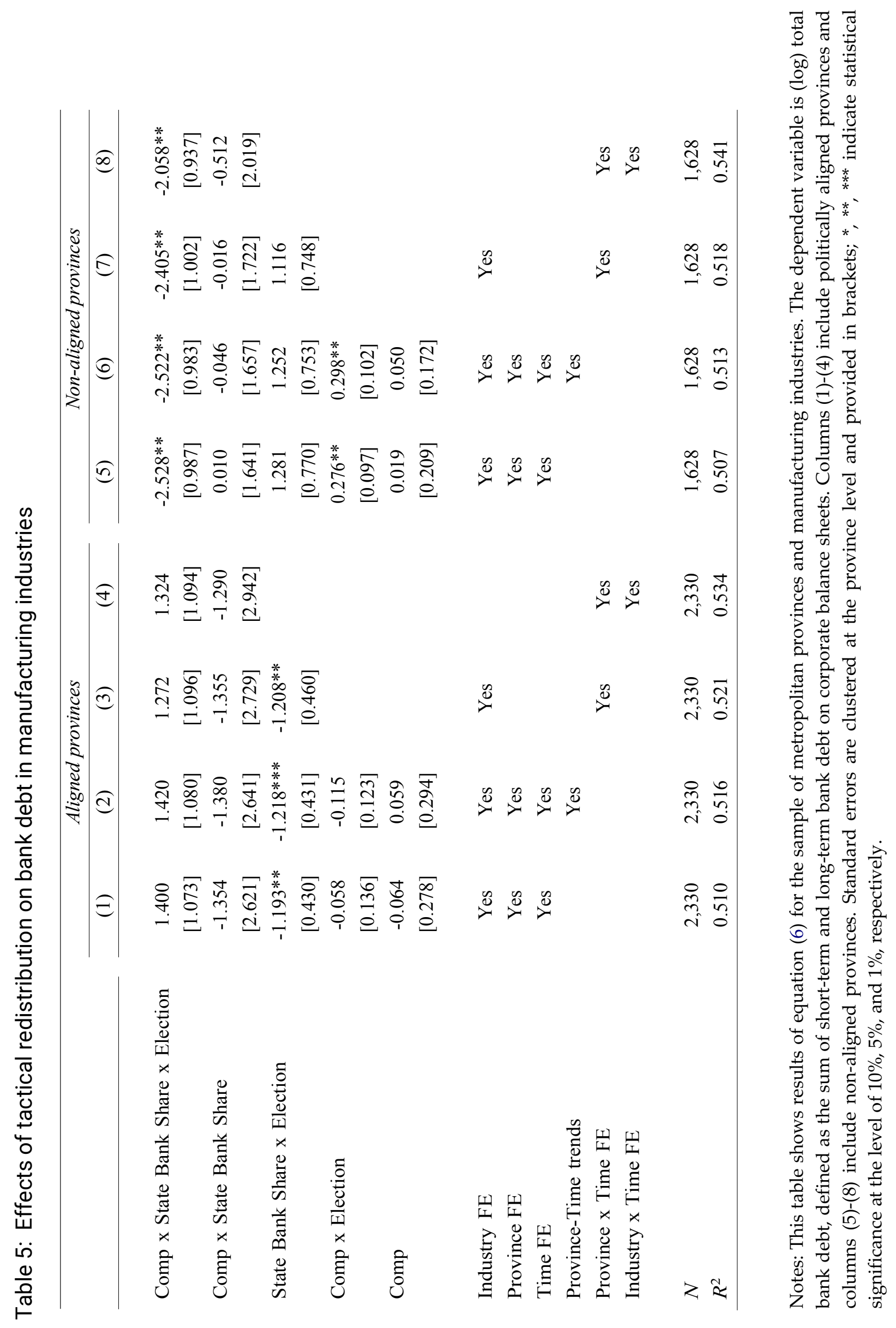




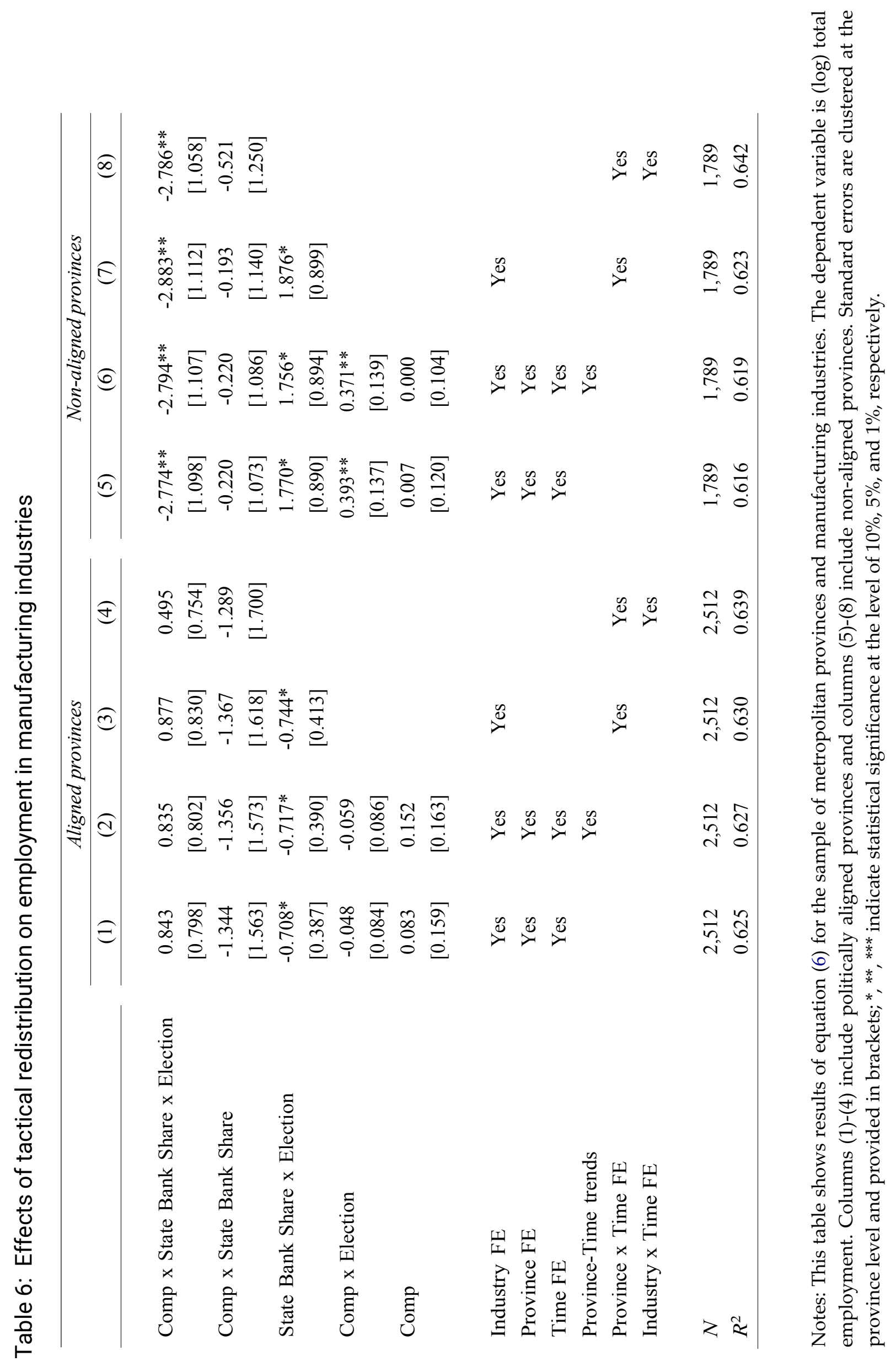




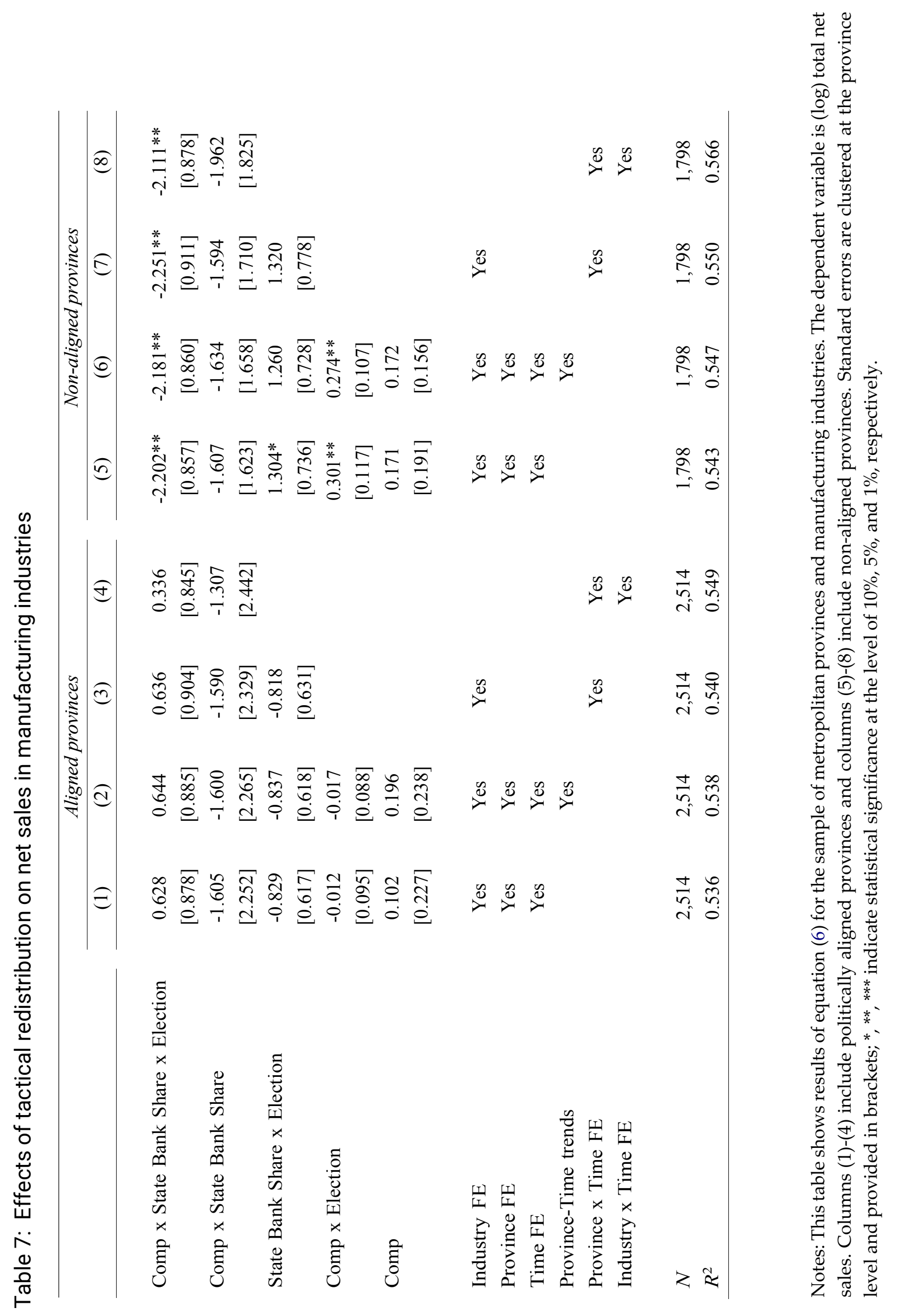



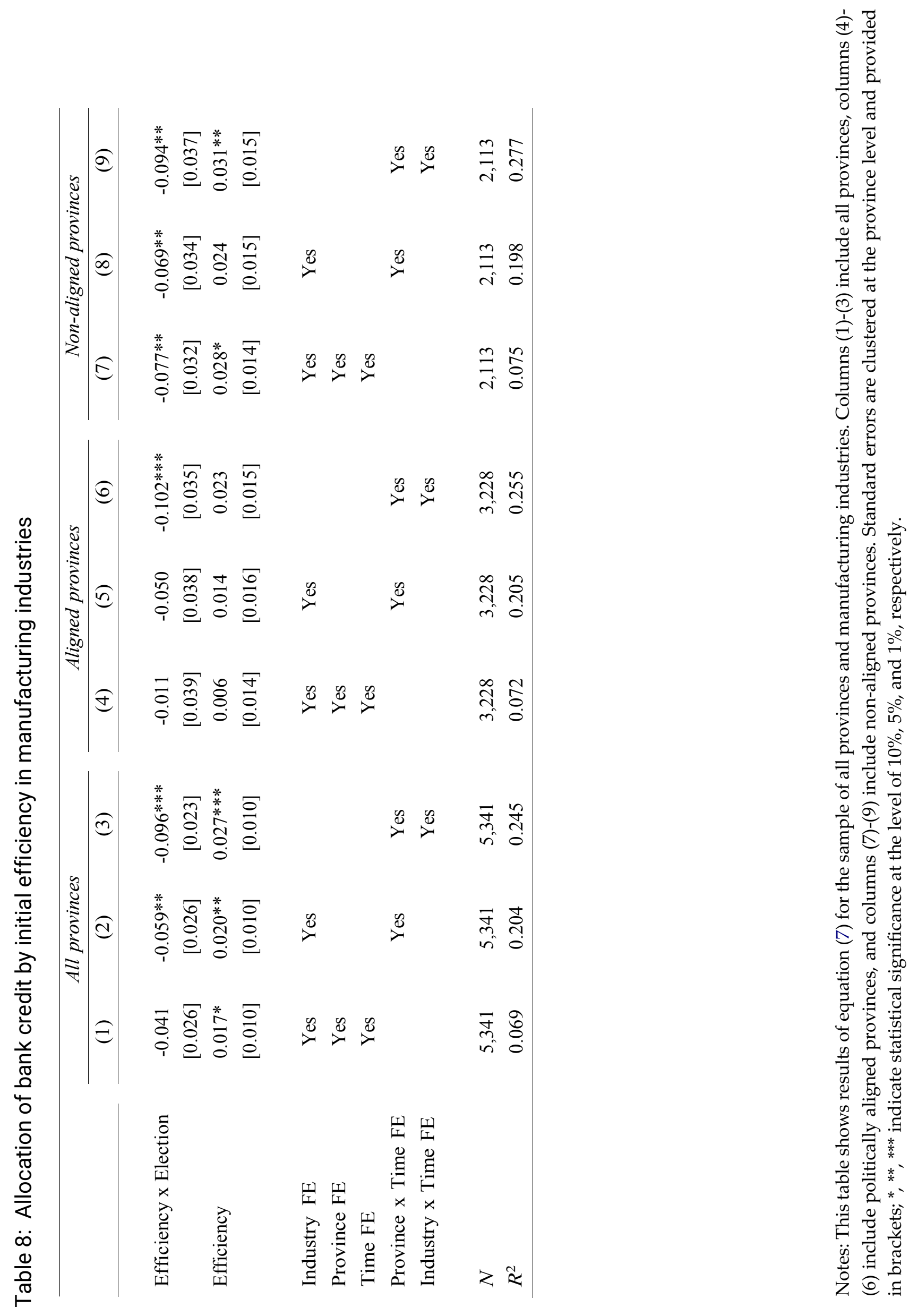


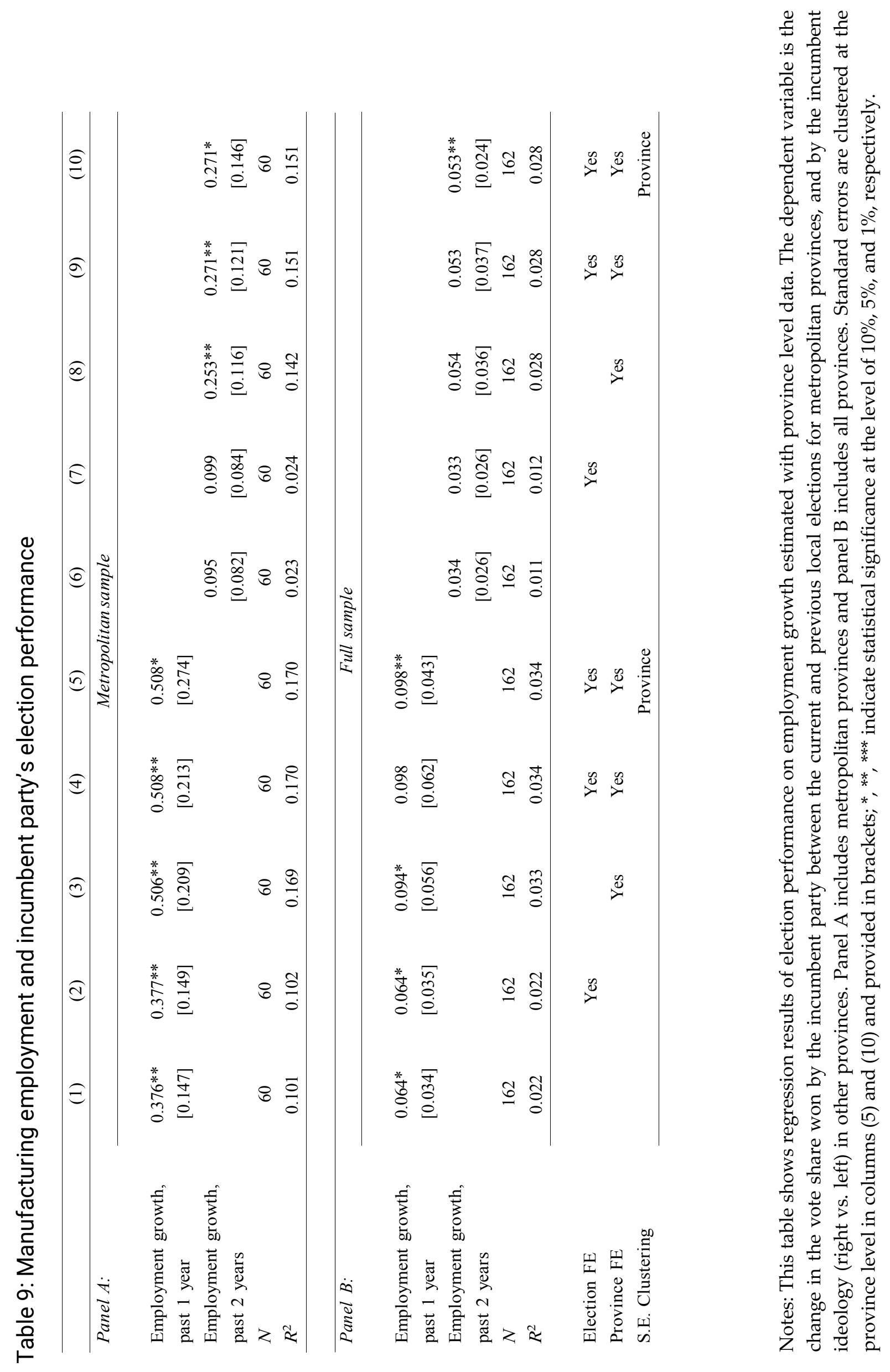




\section{Appendix A}

Figure A.1: State bank lending relative to private banks over the election cycle: Yearly estimates (2003-2017)

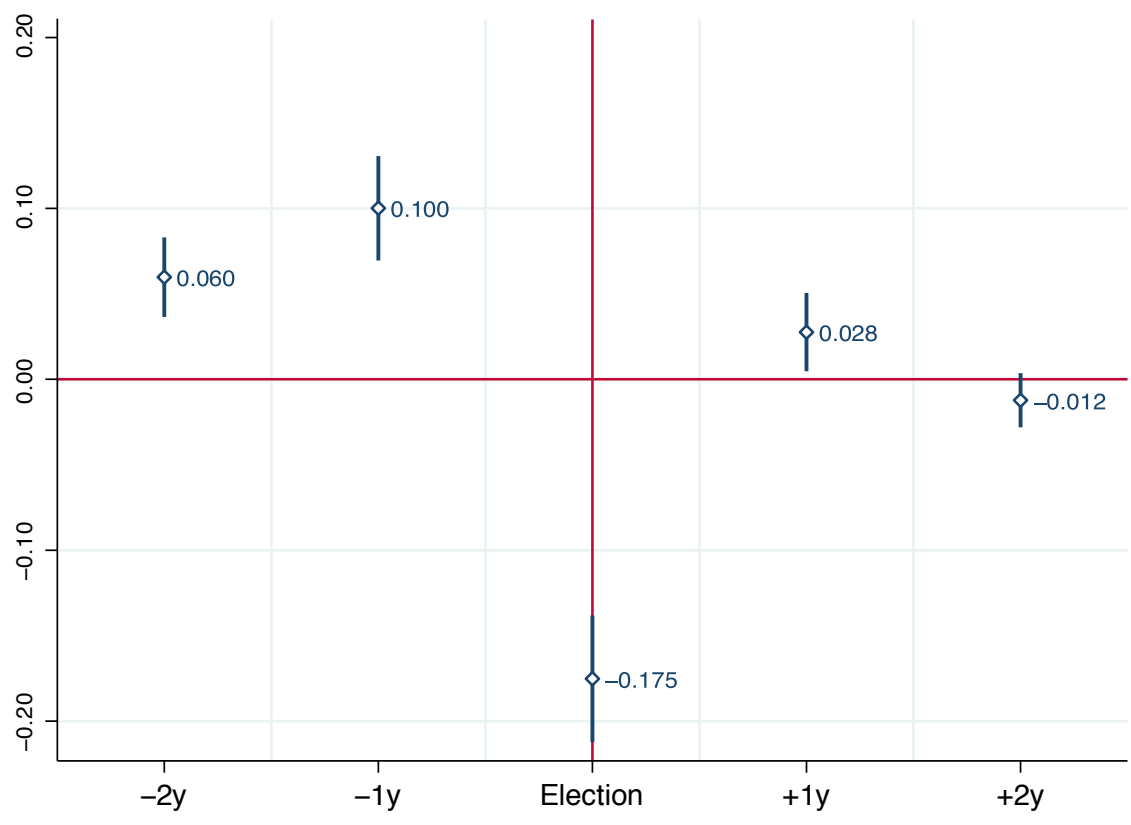

(a) Sample: Metropolitan provinces

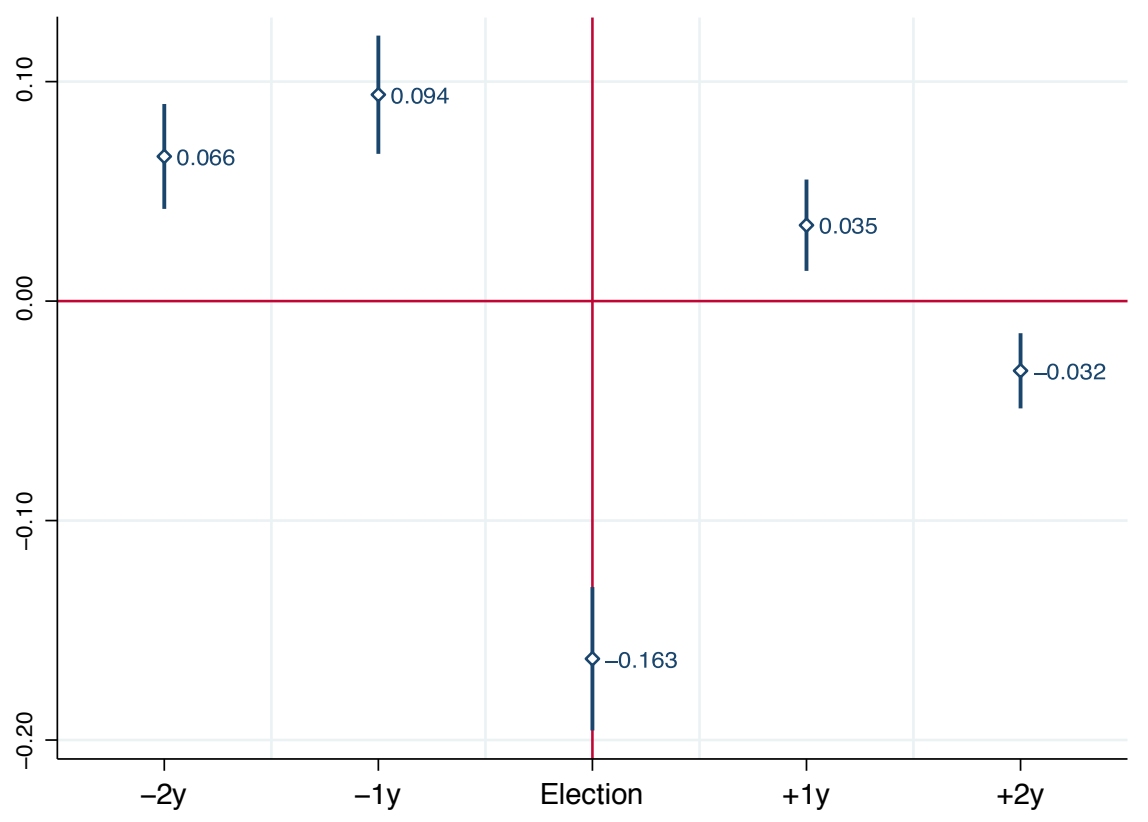

(b) Sample: All provinces

Notes: This figure shows results of equation (1) estimated on yearly data when $\tau$ takes values from -2 to +2 , indicating the number of years around elections. Each plotted coefficient comes from a single regression; bars around estimates show 90\% confidence intervals. Each regression controls for local branches, our baseline set of fixed effects, and province time trends. Panel A includes metropolitan provinces and panel $\mathrm{B}$ includes the full sample. 
Figure A.2: Tactical redistribution of state-bank credit over the election cycle: Yearly estimates (2003-2017)
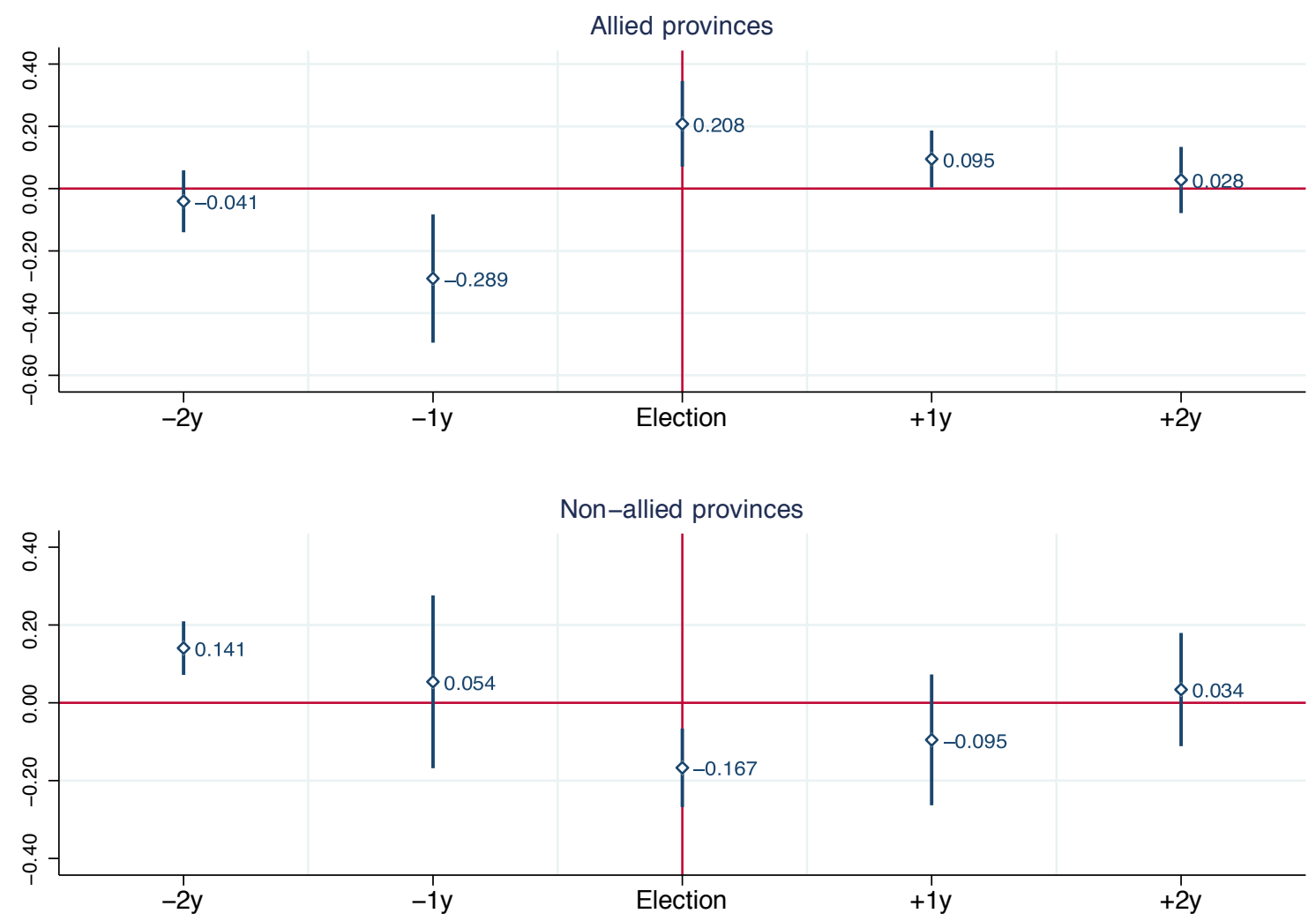

Notes: This figure shows results of equation (2) estimated on yearly data when $\tau$ takes values from -2 to +2 , indicating the number of years around elections. Sample includes metropolitan provinces. Each plotted coefficient comes from a single regression; bars around estimates show $90 \%$ confidence intervals. Each regression controls for local branches, our baseline set of fixed effects, and province time trends. Estimates are reported separately for aligned and non-aligned provinces. 
马ㅇำ

Ð

올

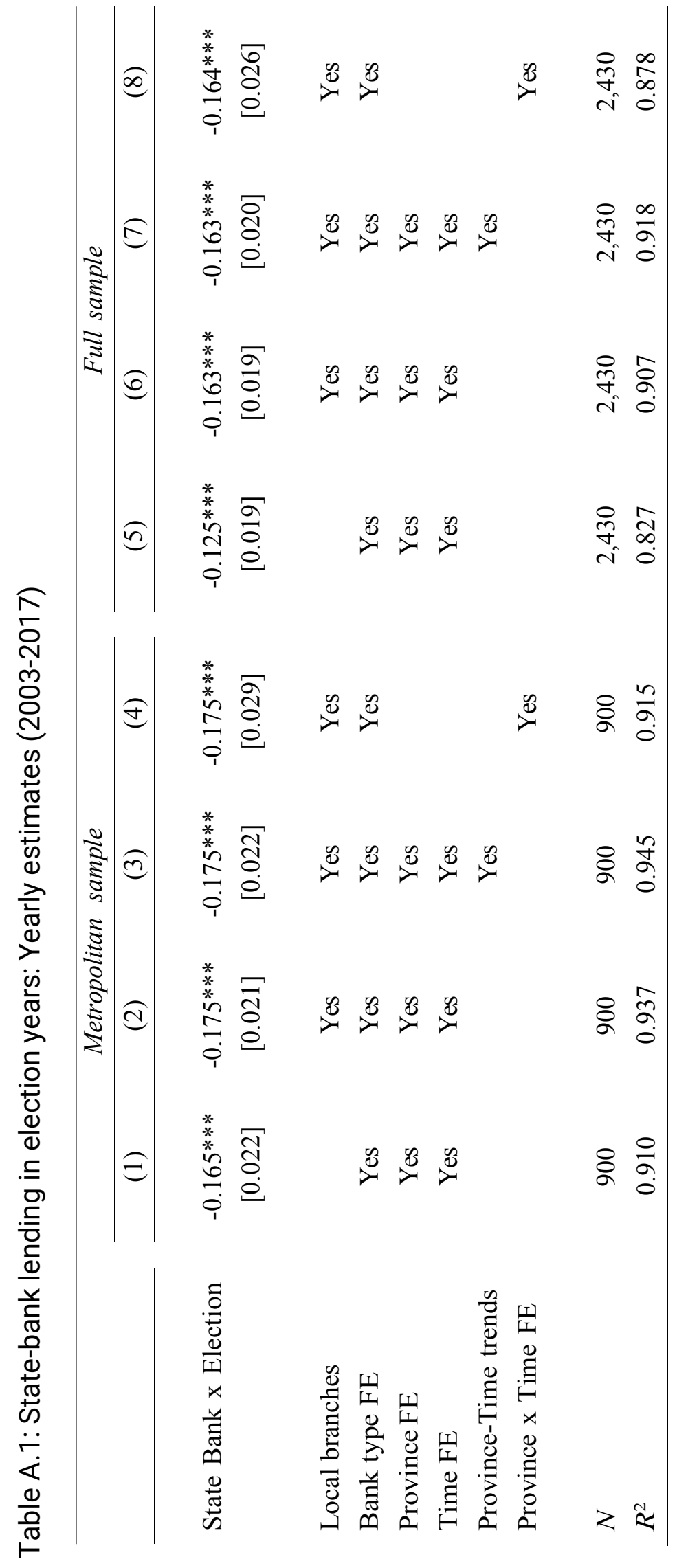



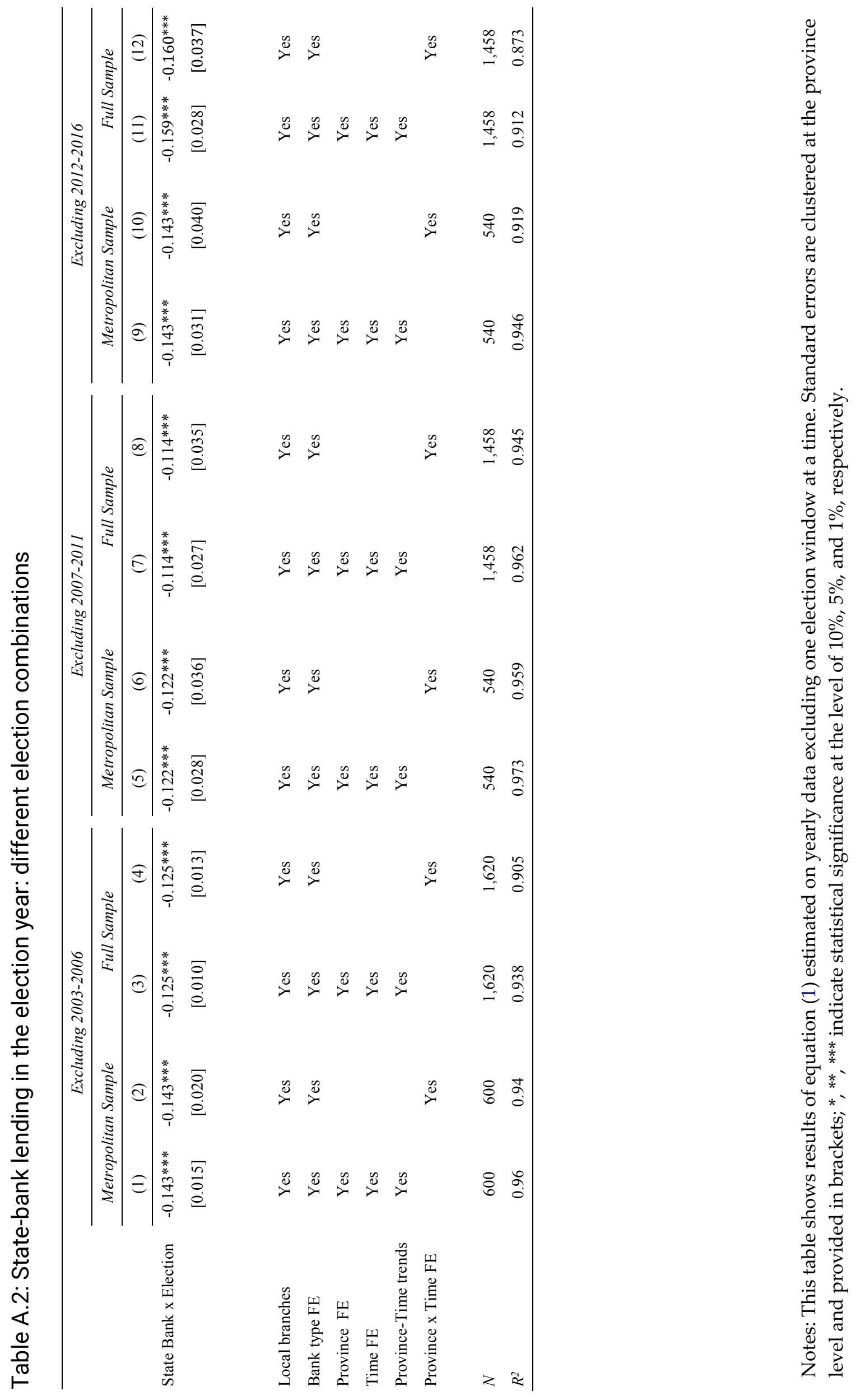


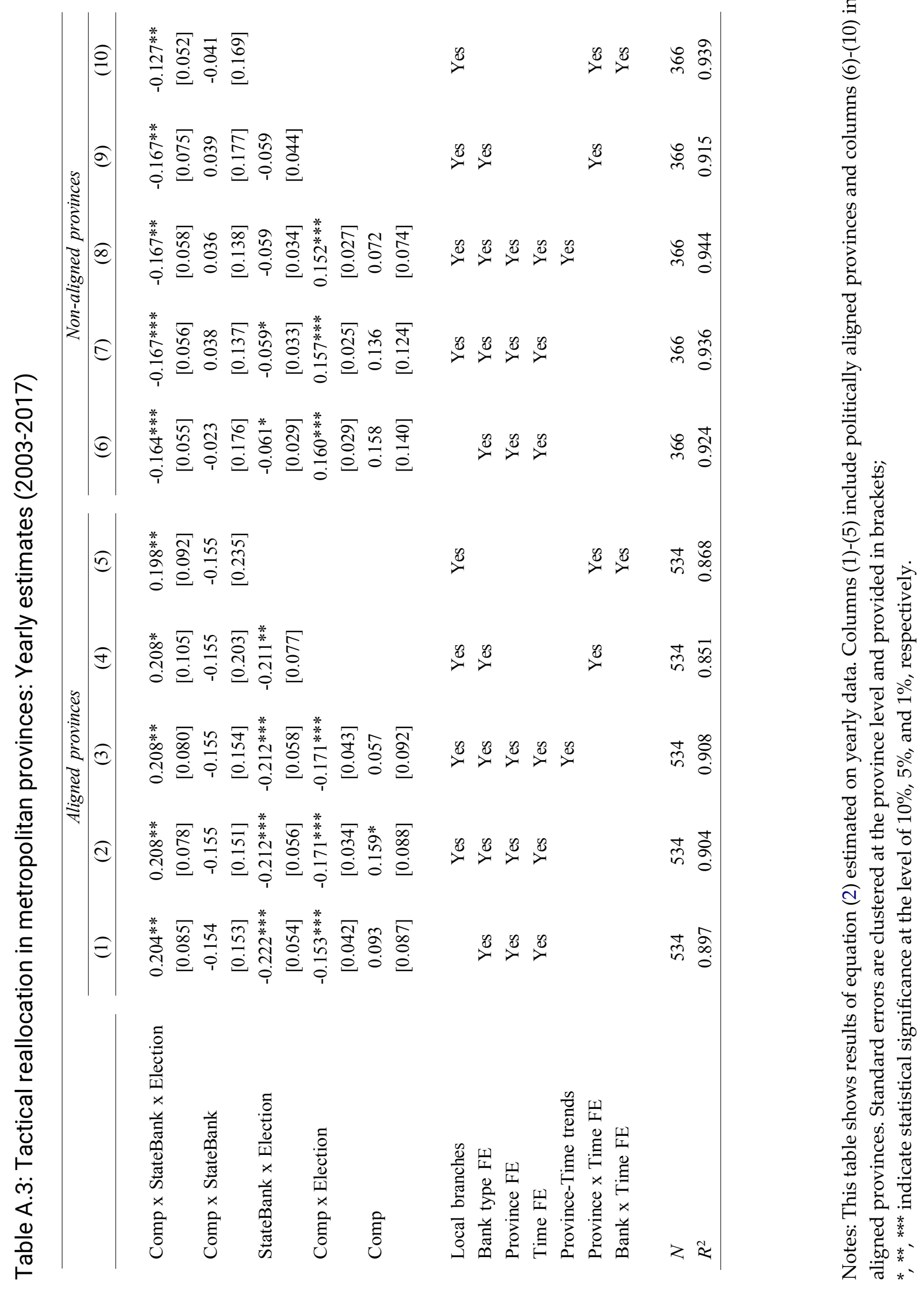




\section{Appendix B}

Figure B.1: Tactical redistribution of state-bank credit over the election cycle: Competition dummy defined by top $25 \%$ of distribution
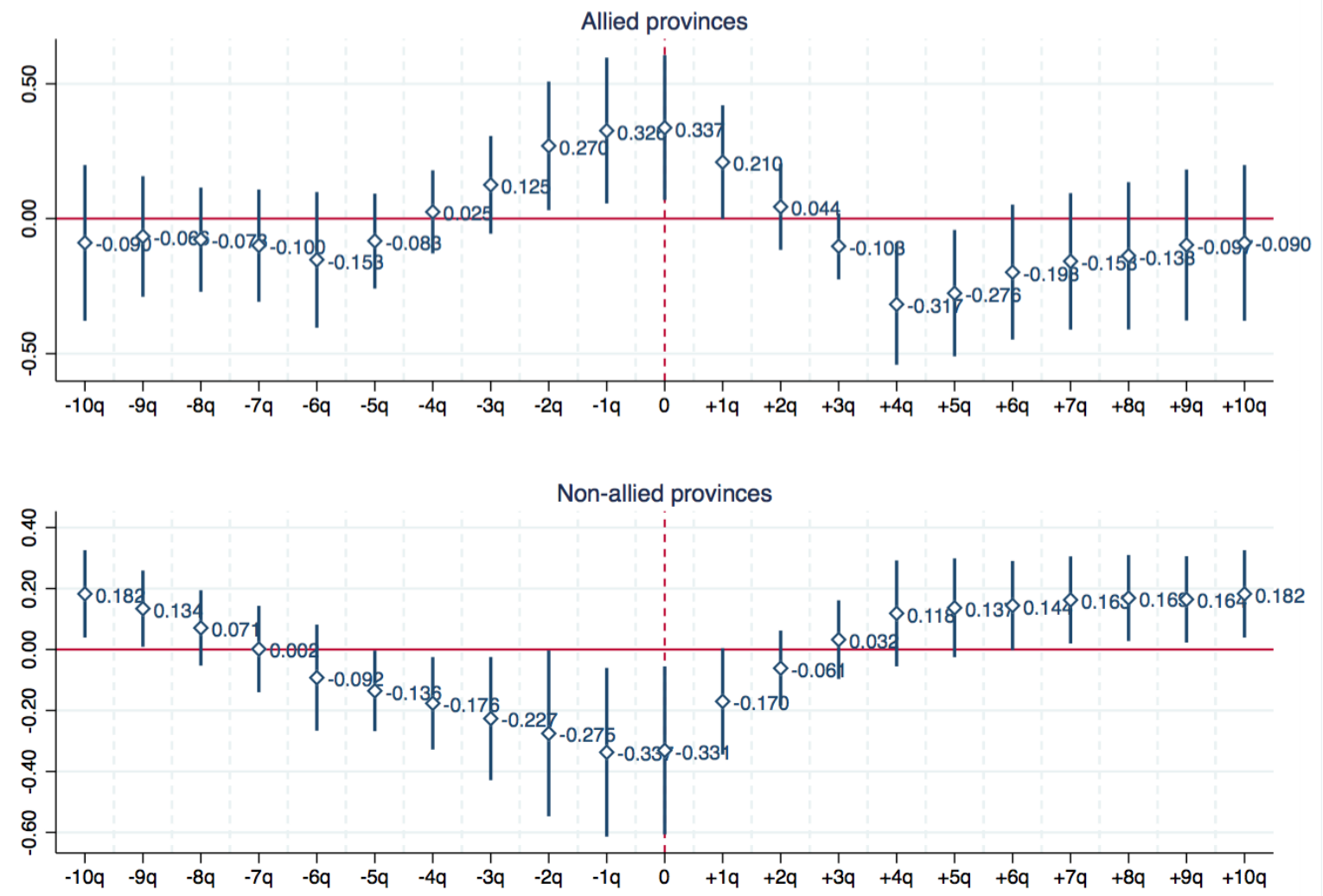

Notes: This figure shows results of equation (2) estimated on quarterly data (2007q4-2017q4) when $\tau$ takes values from -10 to +10 , indicating the number of quarters around elections. Sample includes metropolitan provinces. The competition variable equals 1 for the upper $25 \%$ of the continuous competition variable in the pooled sample of province-years, and 0 otherwise. Each plotted coefficient comes from a single regression; bars around estimates show $90 \%$ confidence intervals. Each regression controls for local branches, our baseline set of fixed effects, and province time trends. Estimates are reported separately for aligned and non-aligned provinces in each panel. 
Figure B.2: Tactical redistribution of state-bank credit over the election cycle: Competition dummy defined by top $50 \%$ of distribution for each election
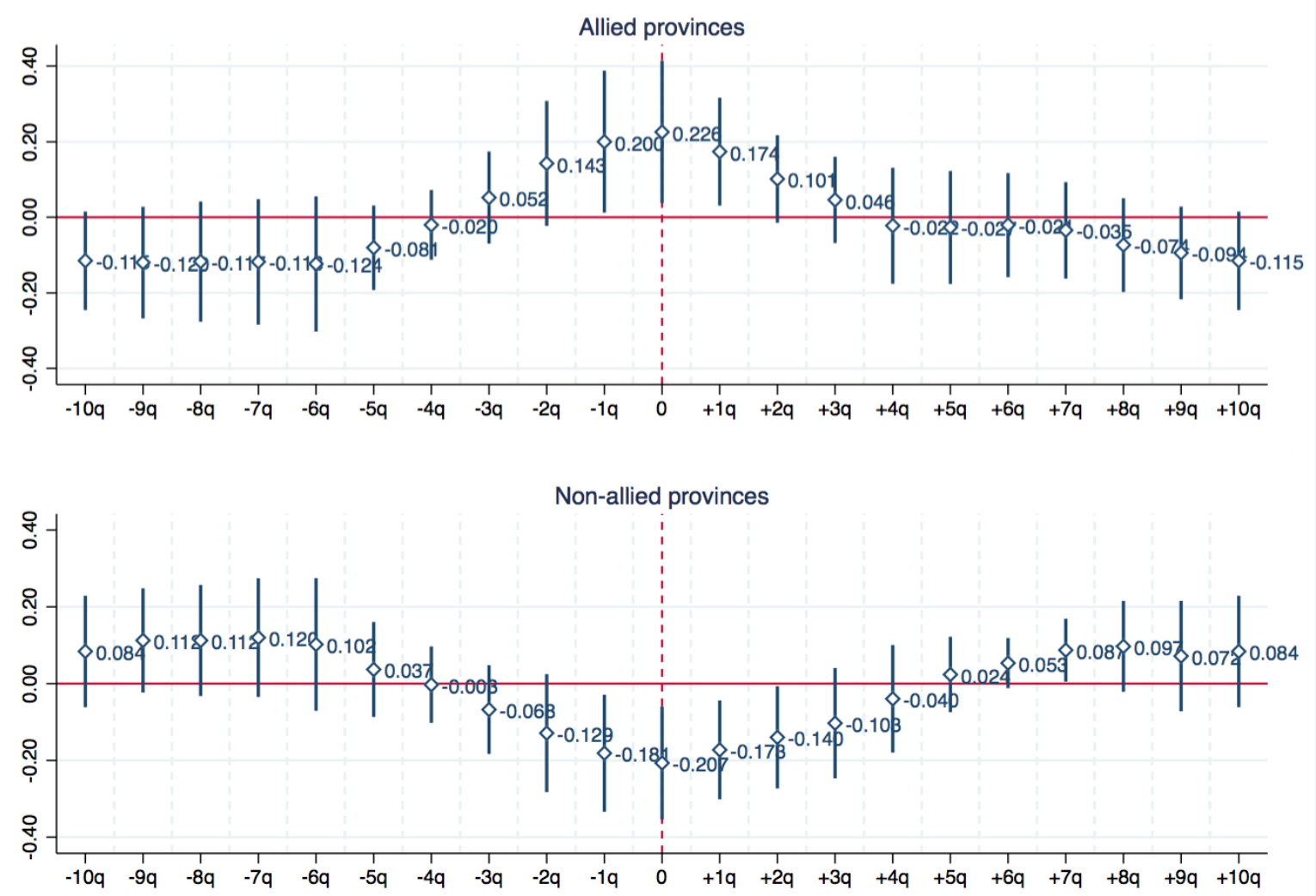

Notes: This figure shows results of equation (2) estimated on quarterly data (2007q4-2017q4) when $\tau$ takes values from -10 to +10 , indicating the number of quarters around elections. Sample includes metropolitan provinces. The competition variable equals 1 for the upper $50 \%$ of the continuous competition variable for each local election separately treated, and 0 otherwise. Each plotted coefficient comes from a single regression; bars around estimates show 90\% confidence intervals. Each regression controls for local branches, our baseline set of fixed effects, and province time trends. Estimates are reported separately for aligned and non-aligned provinces in each panel. 
Figure B.3: Tactical redistribution of state-bank credit over the election cycle: Continuous competition
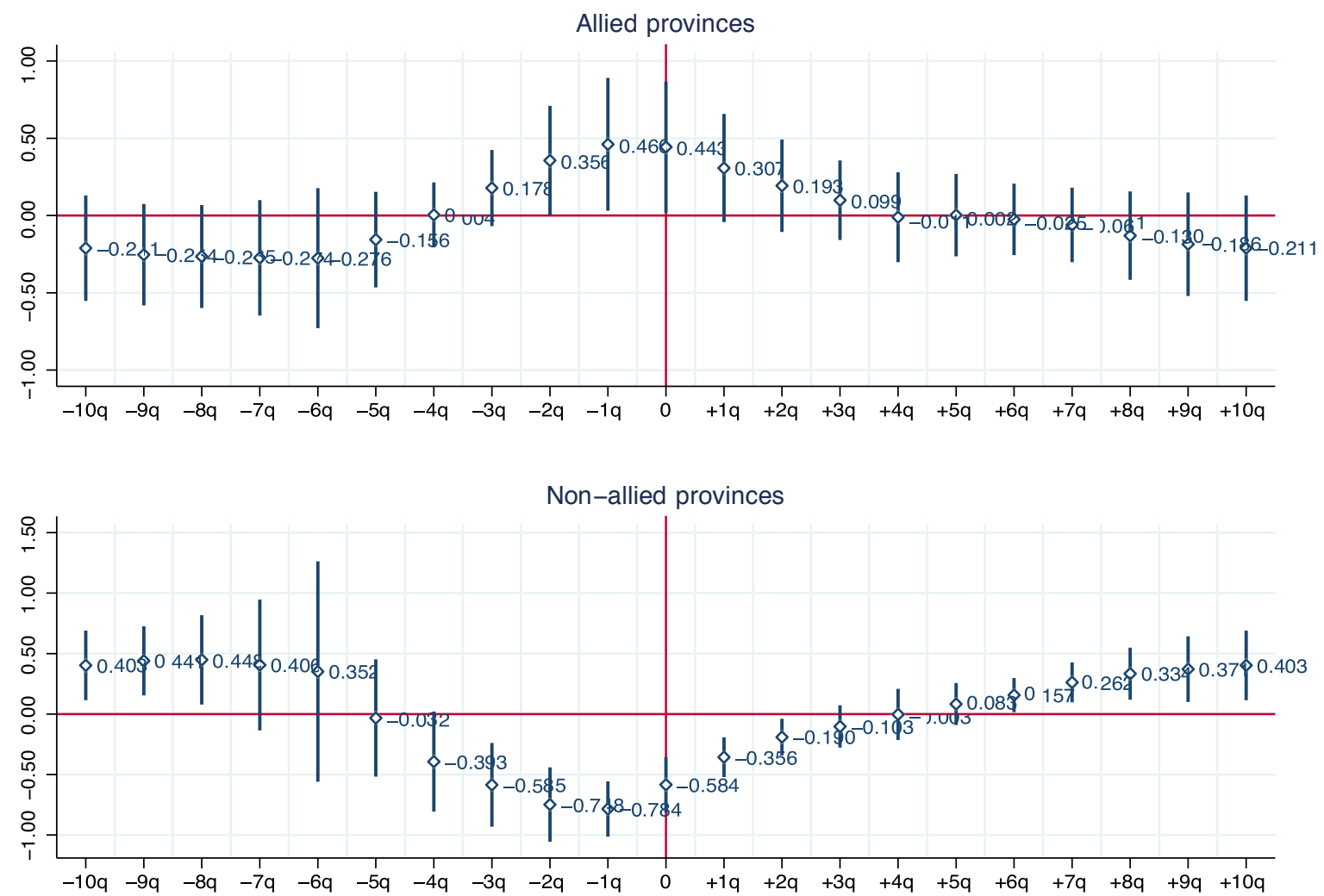

Notes: This figure shows results of equation (2) estimated on quarterly data (2007q4-2017q4) when $\tau$ takes values from -10 to +10 , indicating the number of quarters around elections. Sample includes metropolitan provinces. The competition variable is used in its continuous form. Each plotted coefficient comes from a single regression; bars around estimates show $90 \%$ confidence intervals. Each regression controls for local branches, our baseline set of fixed effects, and province time trends. Estimates are reported separately for aligned and non-aligned provinces in each panel. 
Figure B.4: Tactical redistribution of state-bank credit over the election cycle: Using previous election outcomes to define competition
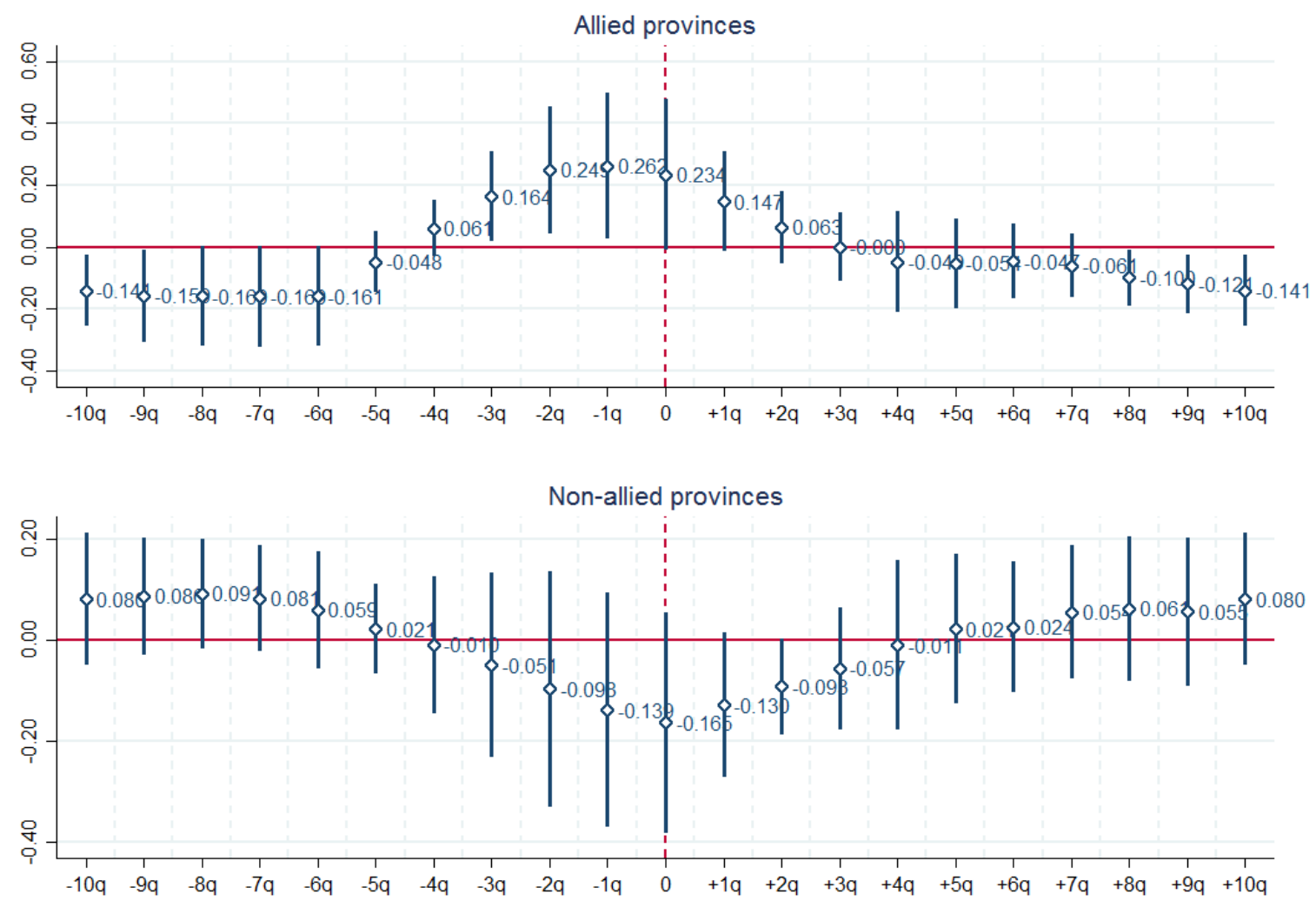

Notes: This figure shows results of equation (2) estimated on quarterly data (2007q4-2017q4) when $\tau$ takes values from -10 to +10 , indicating the number of quarters around elections. Sample includes metropolitan provinces. The competition variable equals 1 for the upper $50 \%$ of the continuous competition variable based on previous election's outcome, and 0 otherwise. Each plotted coefficient comes from a single regression; bars around estimates show 90\% confidence intervals. Each regression controls for local branches, our baseline set of fixed effects, and province time trends. Estimates are reported separately for aligned and non-aligned provinces in each panel. 
Figure B.5: Tactical redistribution of state-bank credit over the election cycle: Controlling for bank branches in continuous form
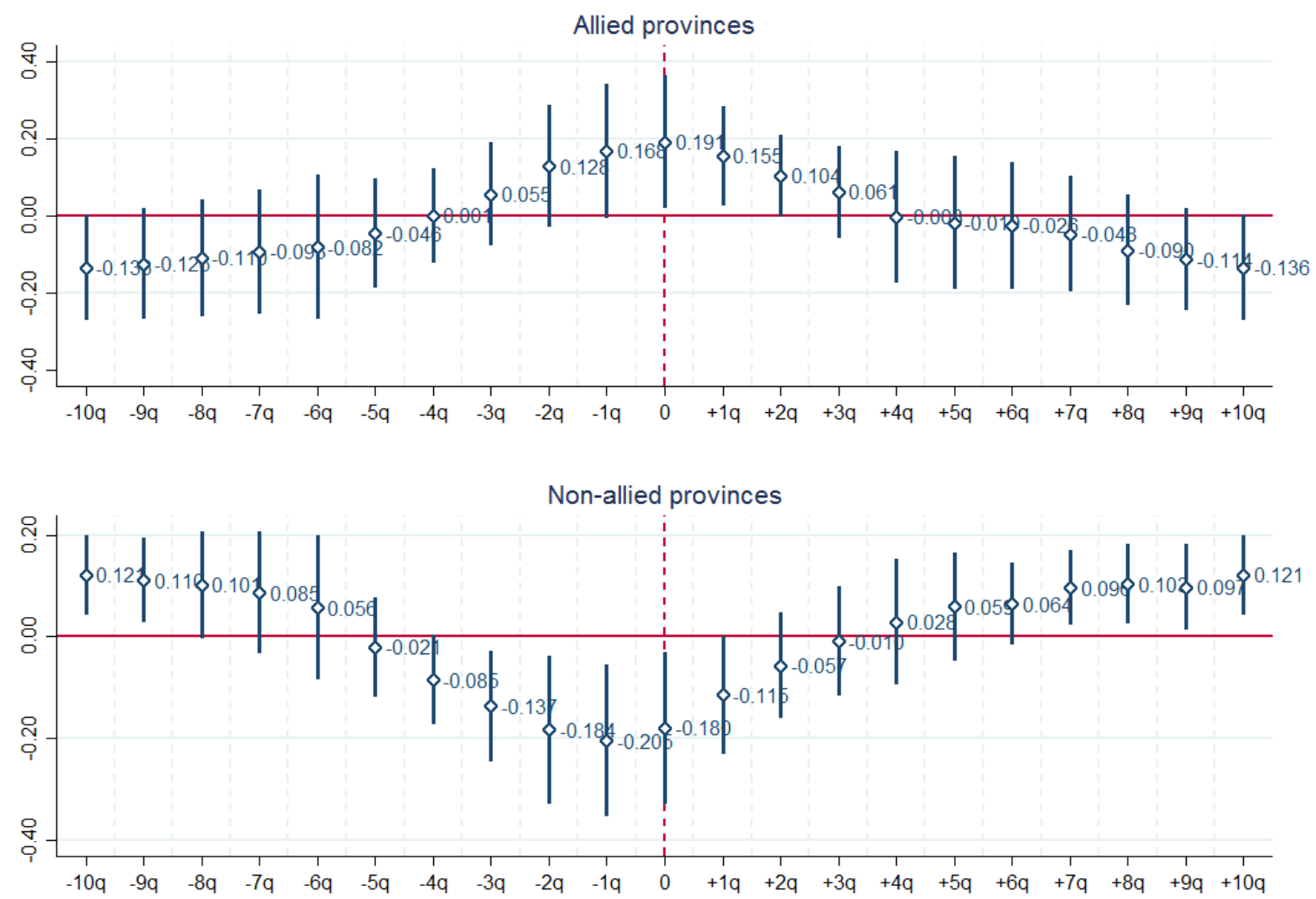

Notes: This figure shows results of equation (2) estimated on quarterly data (2007q4-2017q4) when $\tau$ takes values from -10 to +10 , indicating the number of quarters around elections. Sample includes metropolitan provinces. Bank-province-time controls include bank branches in continuous log form. Each plotted coefficient comes from a single regression; bars around estimates show $90 \%$ confidence intervals. Each regression controls for local branches, our baseline set of fixed effects, and province time trends. Estimates are reported separately for aligned and non-aligned provinces in each panel. 
Figure B.6: Tactical redistribution of state-bank credit over the election cycle: Controlling for customer deposits
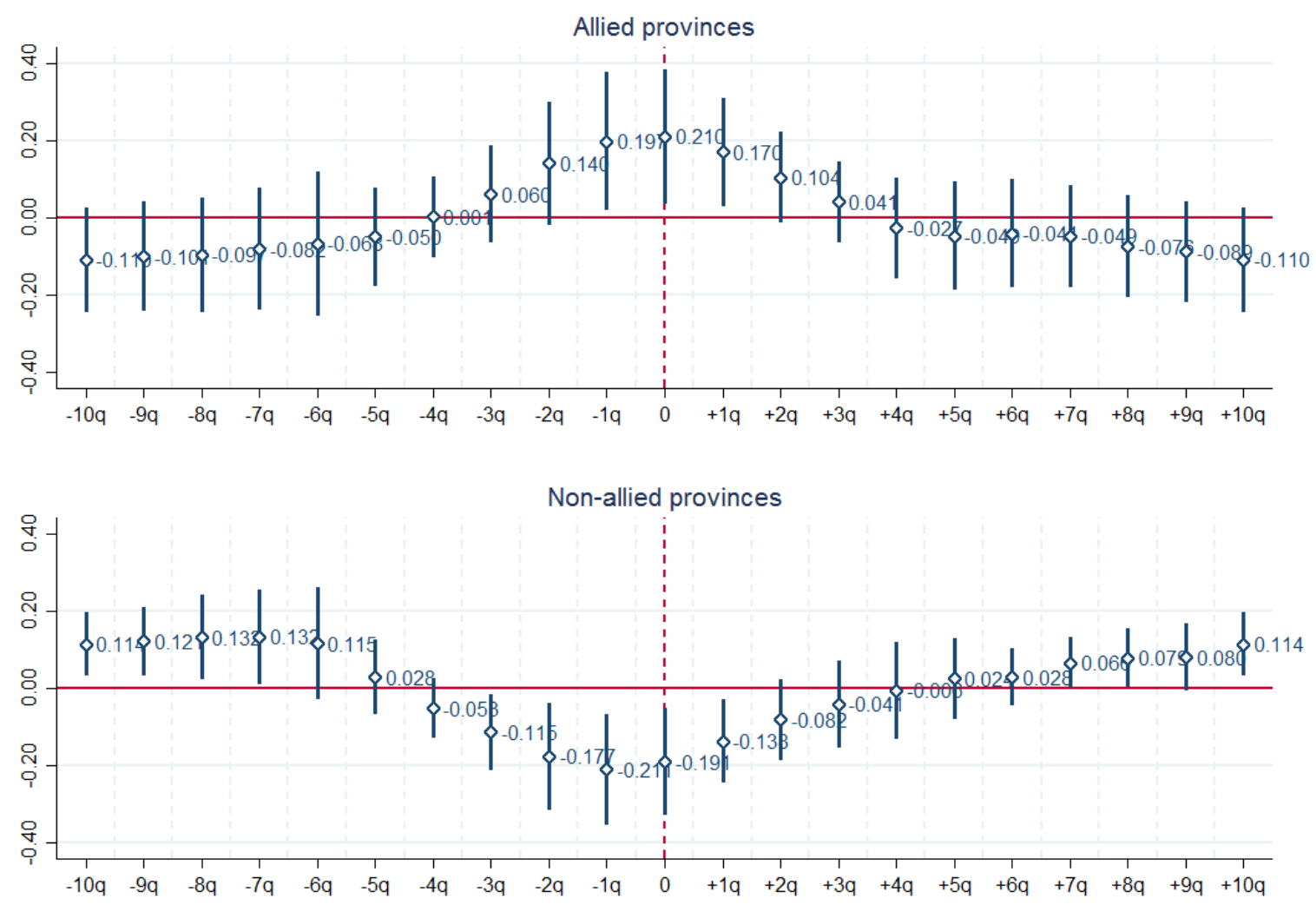

Notes: This figure shows results of equation (2) estimated on quarterly data (2007q4-2017q4) when $\tau$ takes values from -10 to +10 , indicating the number of quarters around elections. Sample includes metropolitan provinces. Bank-province-time controls include customer de- posits in continuous log form. Each plotted coefficient comes from a single regression; bars around estimates show $90 \%$ confidence intervals. Each regression controls for local branches, our baseline set of fixed effects, and province time trends. Estimates are reported separately for aligned and non-aligned provinces in each panel. 
Figure B.7: Tactical redistribution of state-bank credit over the election cycle: Dropping three largest metropolitan cities
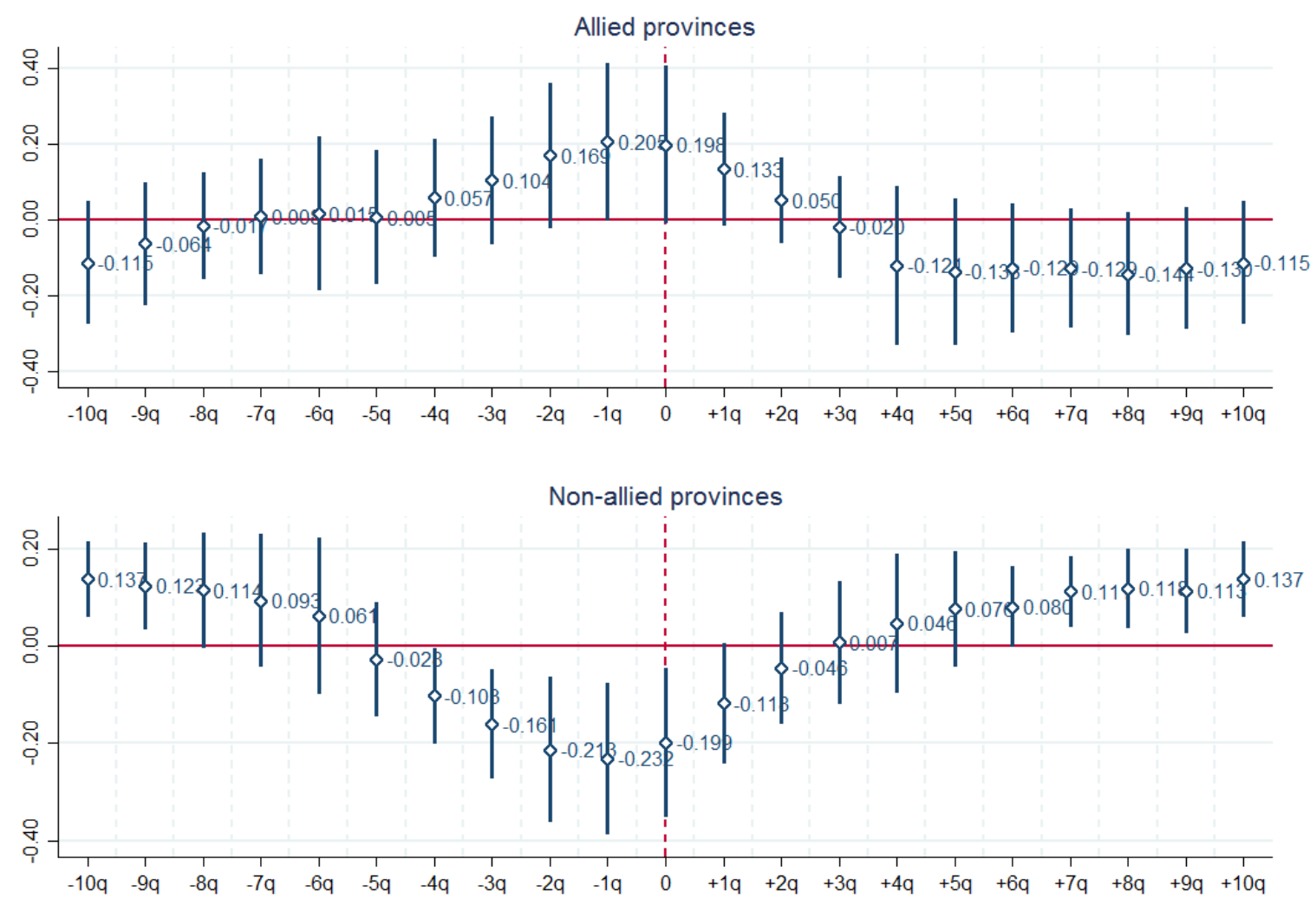

Notes: This figure shows results of equation (2) estimated on quarterly data (2007q4-2017q4) when $\tau$ takes values from -10 to +10 , indicating the number of quarters around elections. Sample includes metropolitan provinces. The estimation sample excludes the three largest metropolitan cities in the country. Each plotted coefficient comes from a single regression; bars around estimates show $90 \%$ confidence intervals. Each regression controls for local branches, our baseline set of fixed effects, and province time trends. Estimates are reported separately for aligned and non-aligned provinces in each panel. 
Figure B.8: Tactical redistribution of state-bank credit over the election cycle: Dropping one local election at a time with yearly data
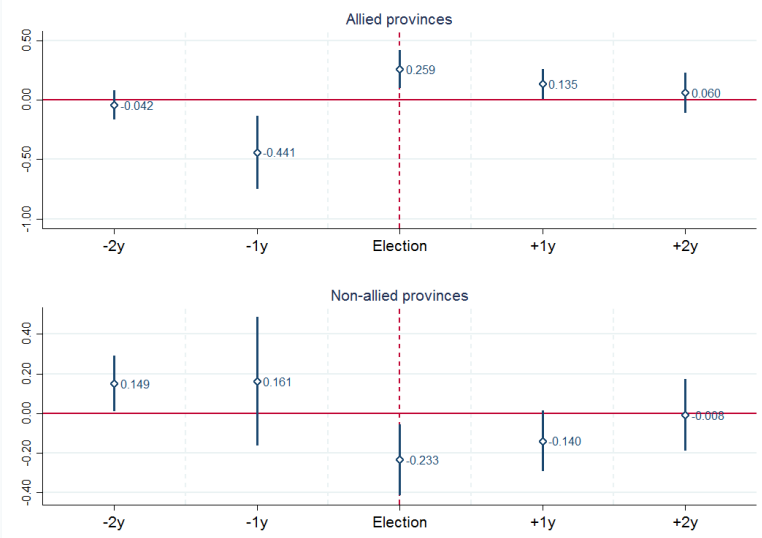

(a) Sample: Excluding 2014 election cycle
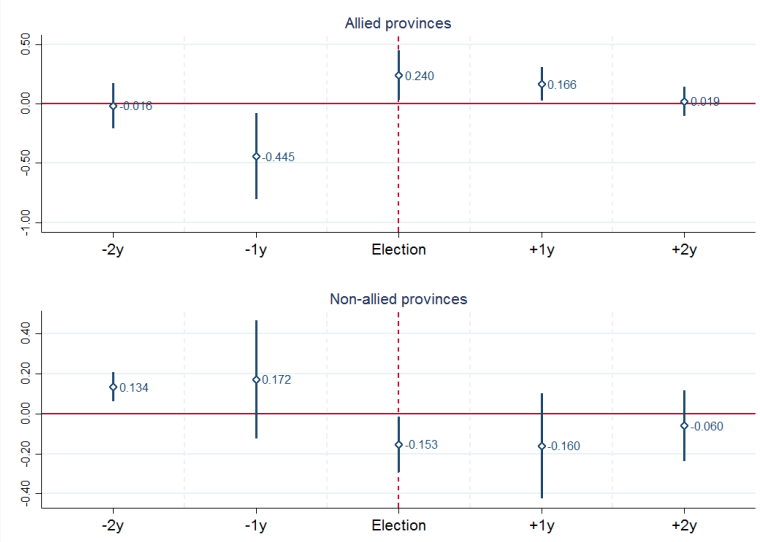

(b) Sample: Excluding 2009 election cycle
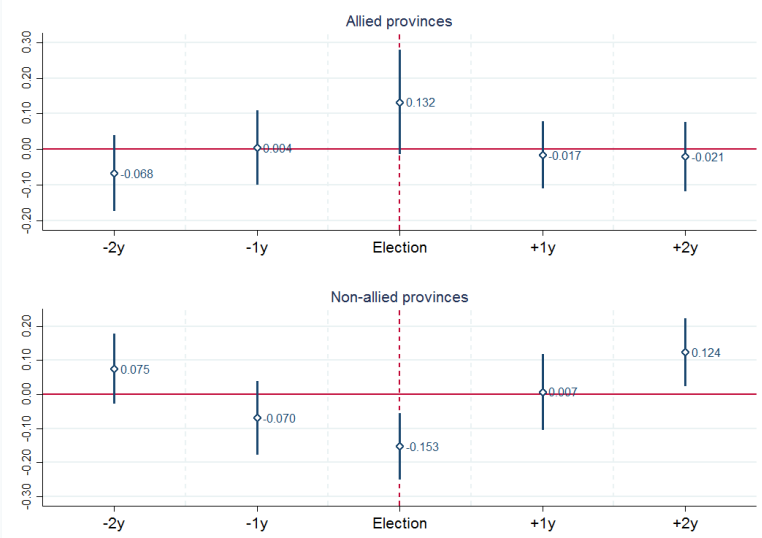

(c) Sample: Excluding 2004 election cycle

Notes: This figure shows results of equation (2) estimated on yearly data (2003-2017) when $\tau$ takes values from -2 to +2 , indicating the number of years around elections. Sample includes metropolitan provinces. Each plotted coefficient comes from a single regression; bars around estimates show $90 \%$ confidence intervals. Each regression our baseline controls and province time trends. Estimates are reported separately for aligned and non-aligned provinces in each panel. 
Figure B.9: Tactical redistribution of state-bank credit over the election cycle: Excluding foreign bank lending from the reference group
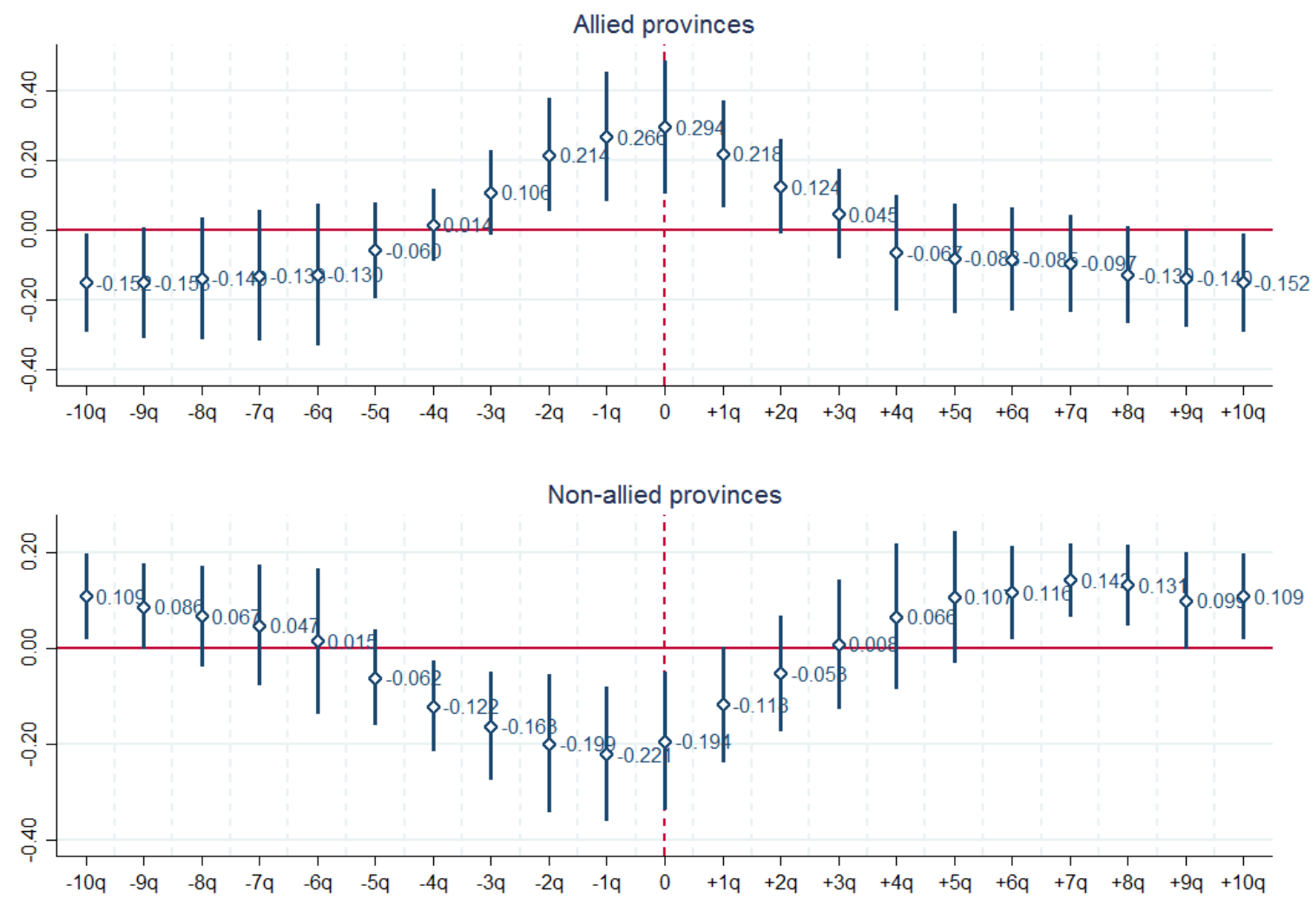

Notes: This figure shows results of equation (2) estimated on quarterly data (2007q4-2017q4) when $\tau$ takes values from -10 to +10 , indicating the number of quarters around elections. Sample includes metropolitan provinces. The reference group only includes domestic private banks and excludes foreign bank lending. Each plotted coefficient comes from a single regression; bars around estimates show $90 \%$ confidence intervals. Each regression controls for local branches, our baseline set of fixed effects, and province time trends. Estimates are reported separately for aligned and non-aligned provinces in each panel. 
Figure B.10: Political uncertainty and bank lending

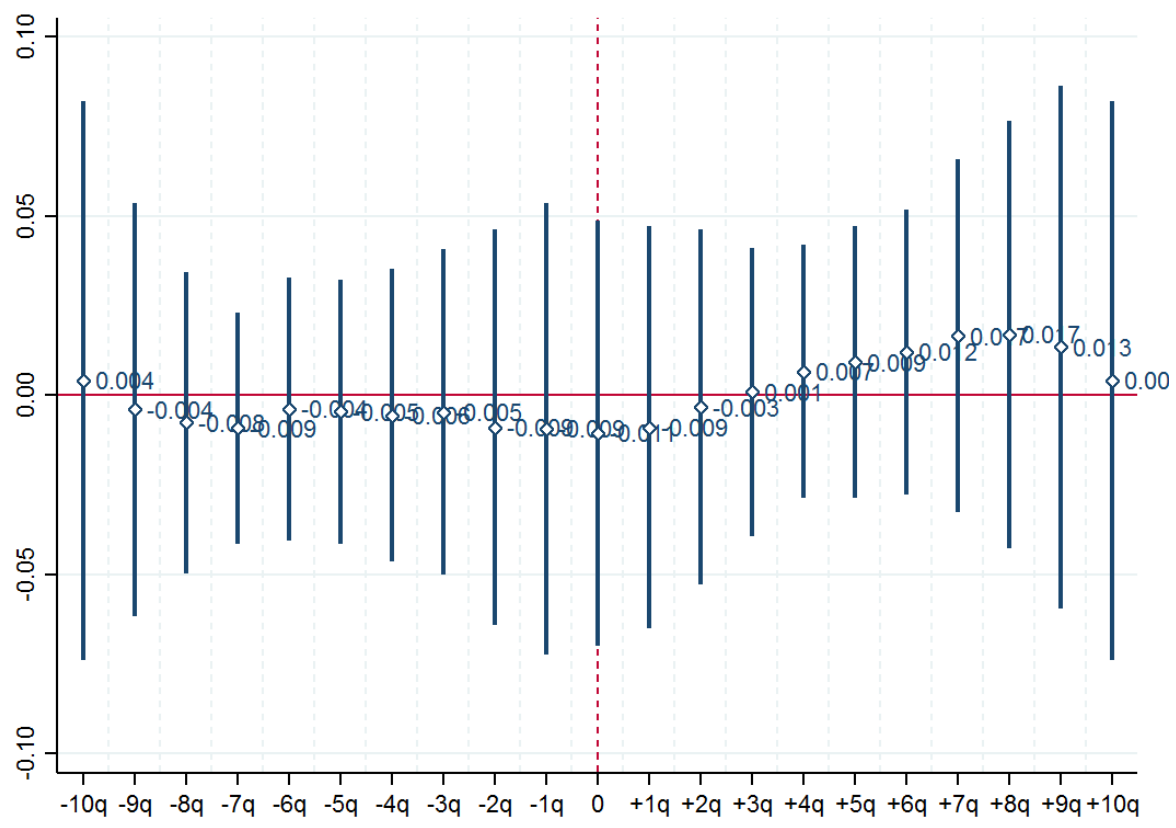

(a) Sample: Quarterly data, 2007q4-2017q4

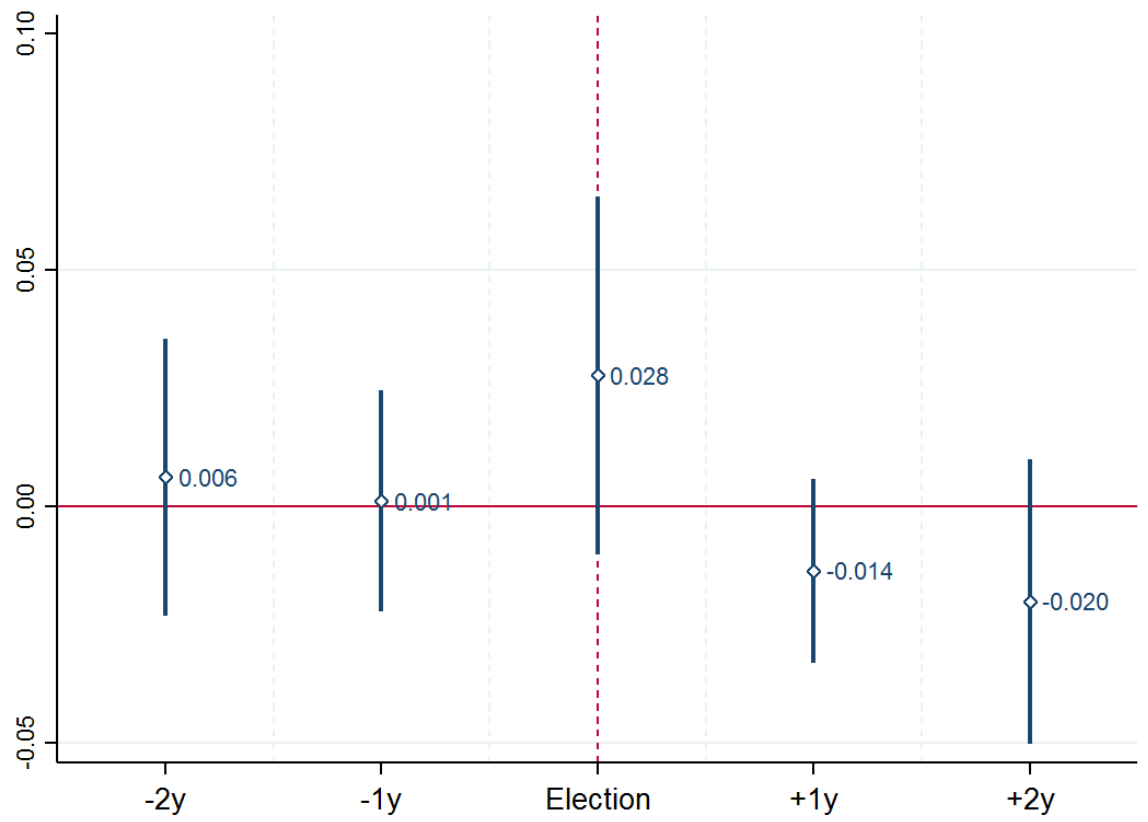

(b) Sample: Yearly data, 2003-2017

Notes: This figure shows results of equation (3) estimated on quarterly data (2007q4-2017q4) when $\tau$ takes values from -10 to +10 in panel $A$, and on yearly data (2003-2017) when $\tau$ takes values from -2 to +2 in panel B. Sample includes metropolitan provinces. Each plotted coefficient comes from a single regression; bars around estimates show $90 \%$ confidence intervals. Each regression controls for local branches, our baseline set of fixed effects, and province time trends. Estimates are reported separately for aligned and non-aligned provinces in each panel. 
Figure B.11: Political uncertainty and state-bank lending relative to private banks

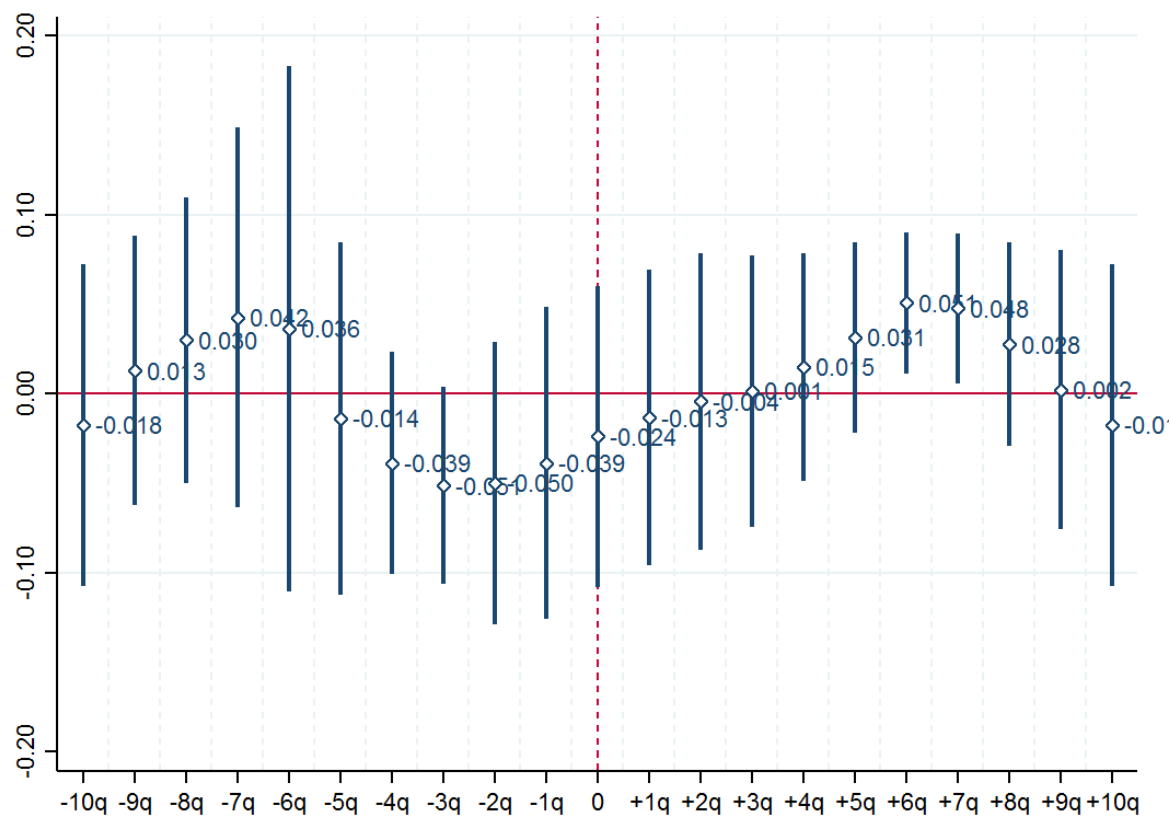

(a) Sample: Quarterly data, 2007q4-2017q4

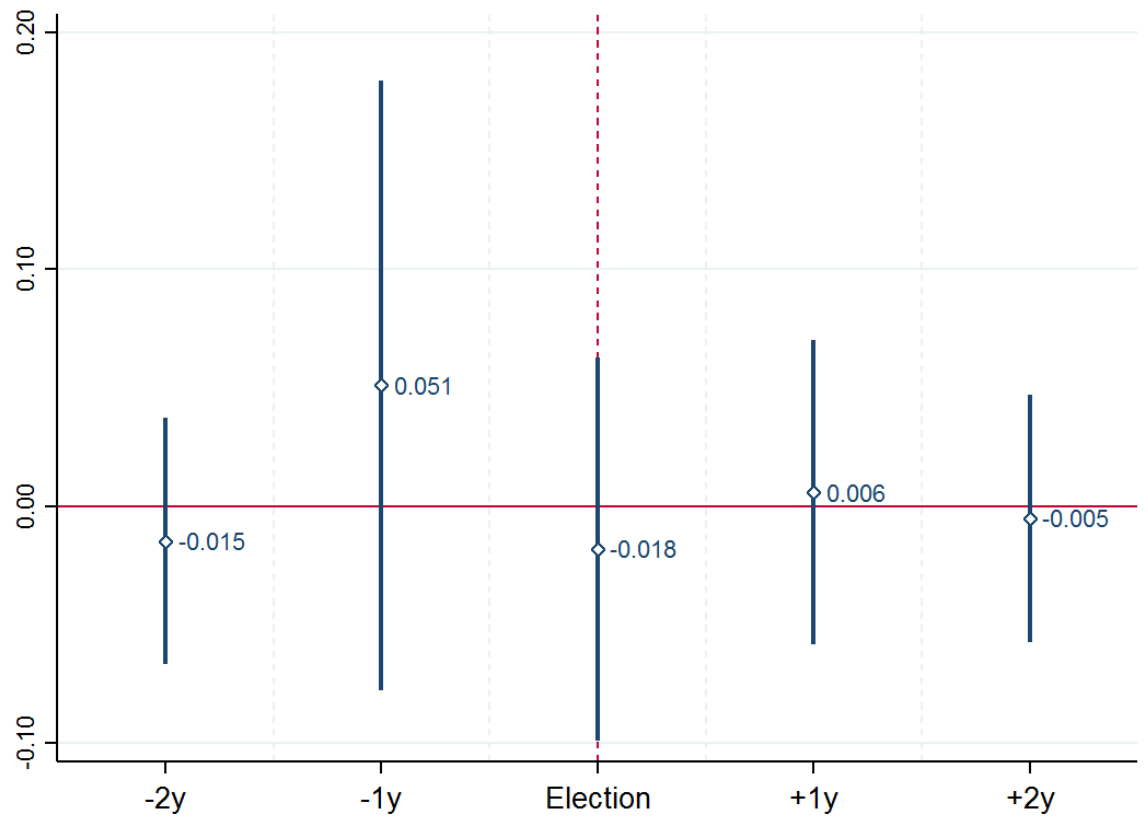

(b) Sample: Yearly data, 2003-2017

Notes: This figure shows results of equation (4) estimated on quarterly data (2007q4-2017q4) when $\tau$ takes values from -10 to +10 in panel $A$, and on yearly data (2003-2017) when $\tau$ takes values from -2 to +2 in panel B. Sample includes metropolitan provinces. Each plotted coefficient comes from a single regression; bars around estimates show $90 \%$ confidence intervals. Each regression controls for local branches, our baseline set of fixed effects, and province time trends. Estimates are reported separately for aligned and non-aligned provinces in each panel. 
Figure B.12: Is there a political cycle in investment incentive certificates?
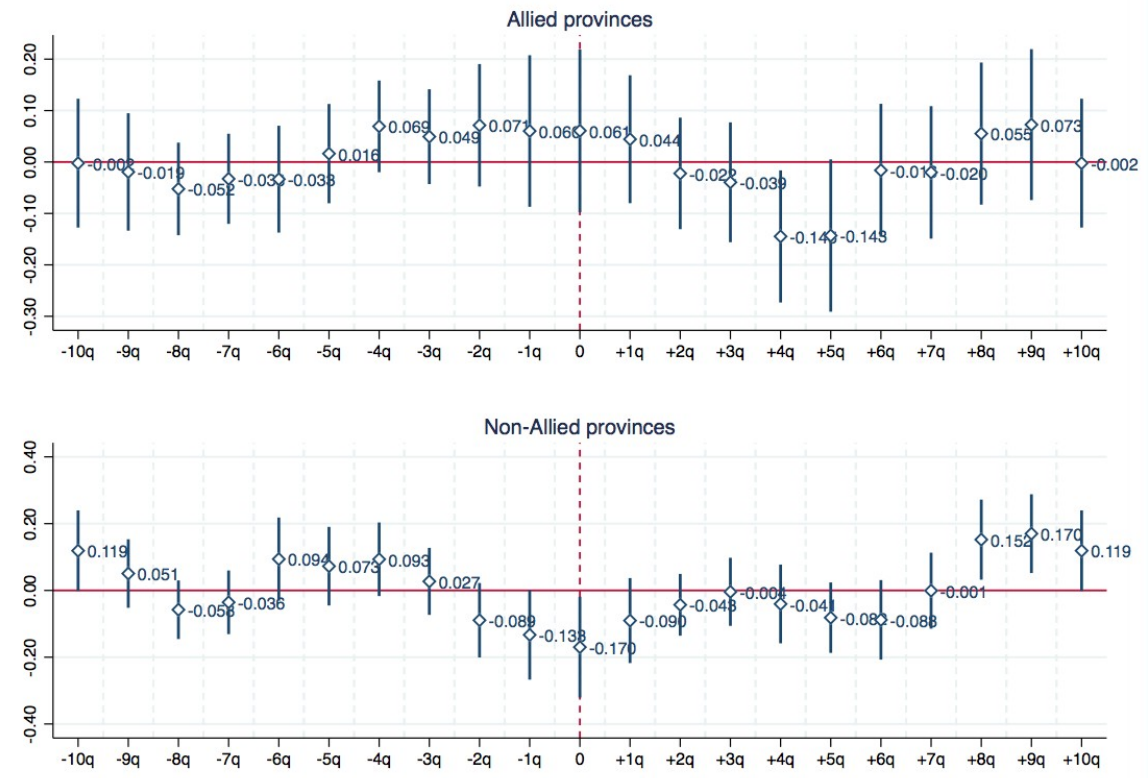

(a) Dependent variable: Number of investment incentive certificates awarded
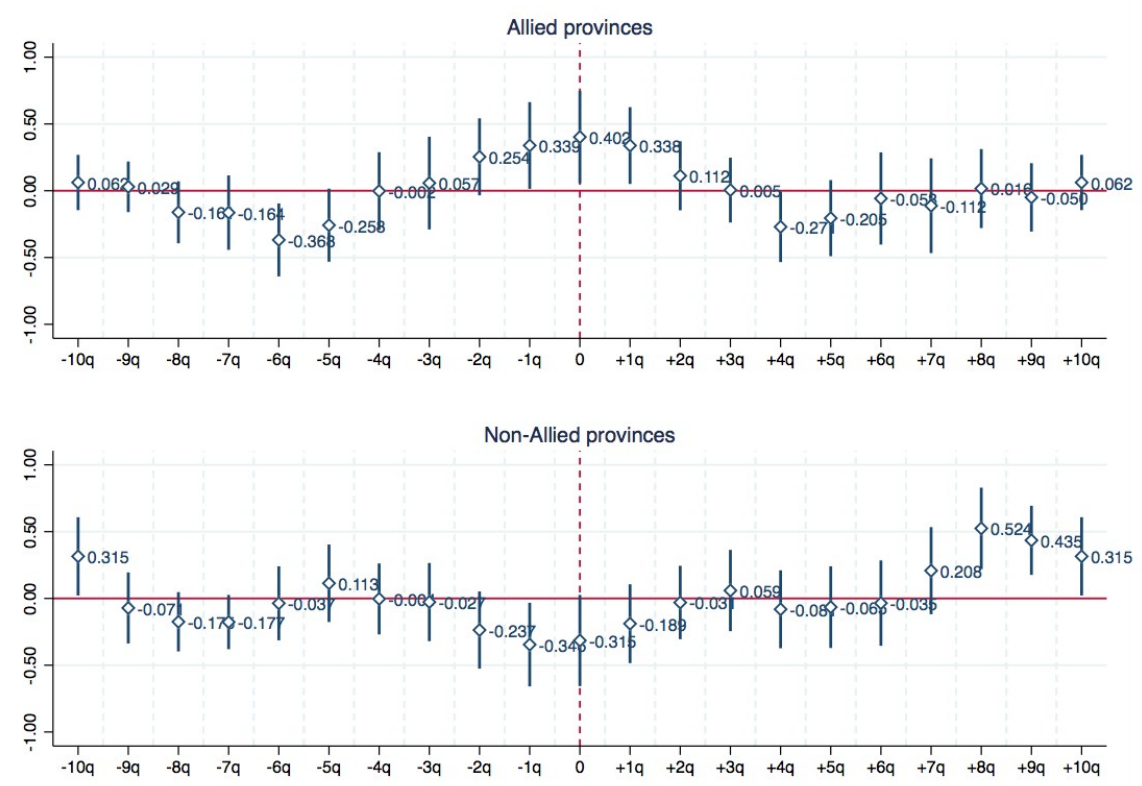

(b) Dependent variable: Number of jobs promised by certificate recipients

Notes: This figure shows results of equation (5) estimated on quarterly data (2003q1-2017q4) when $\tau$ takes values from -10 to +10 , indicating the number of quarters around elections. Sample includes all provinces. Each plotted coefficient comes from a single regression; bars around estimates show $90 \%$ confidence intervals. Each regression controls for province and time fixed effects. Estimates are reported separately for aligned and non-aligned provinces in each panel. 
Figure B.13: Is there a political cycle in new public construction?
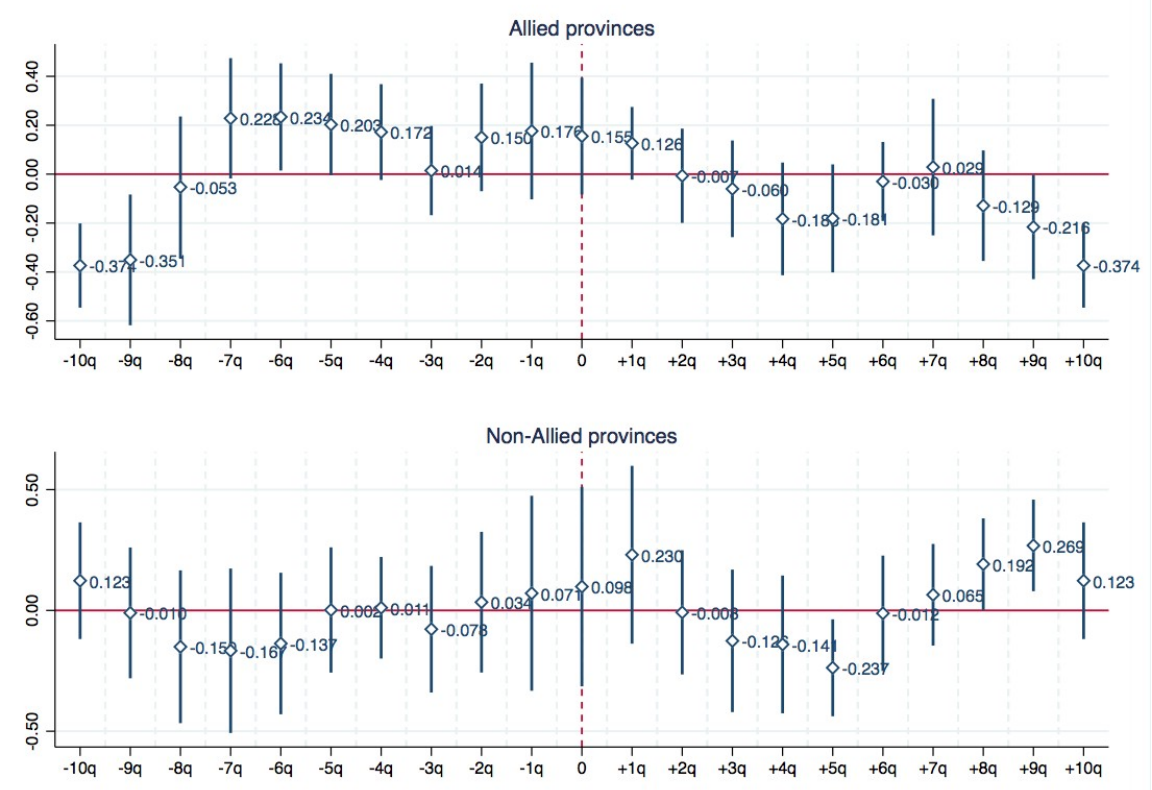

(a) Dependent variable: Number of new buildings started by public sector
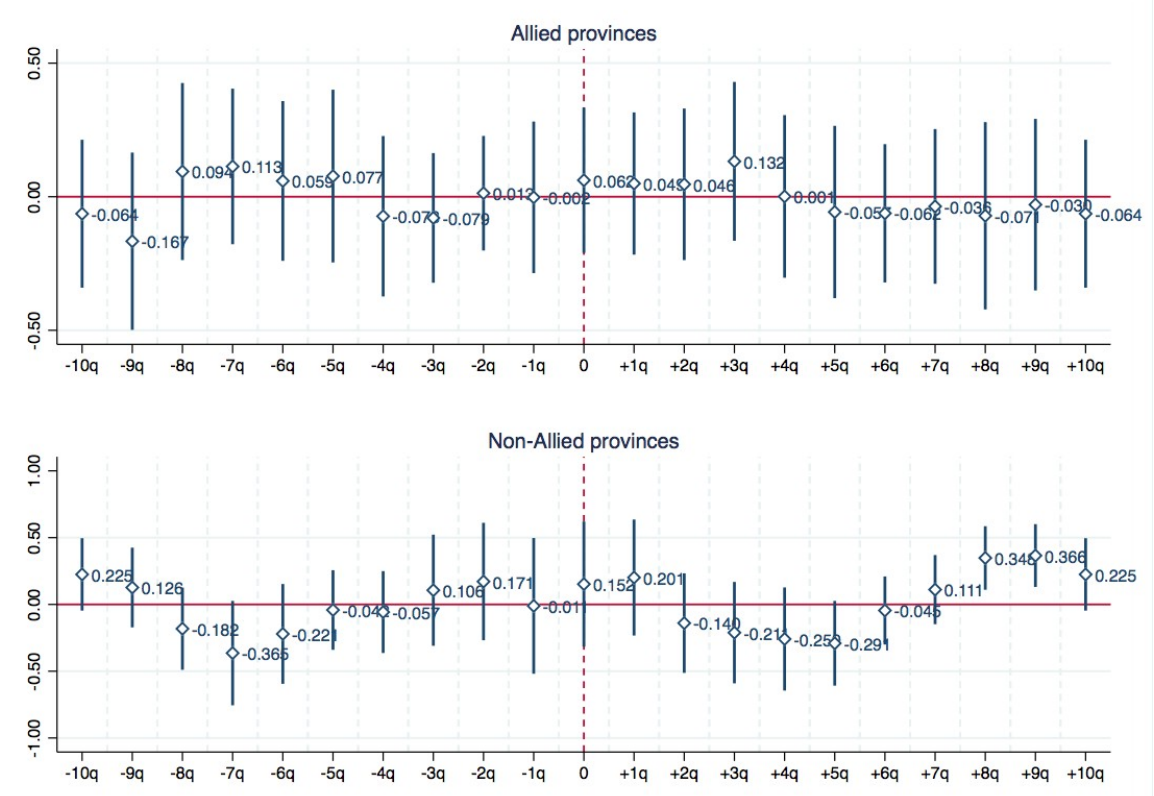

(b) Dependent variable: Total building area started by public sector

Notes: This figure shows results of equation (5) estimated on quarterly data (2003q1-2017q4) when $\tau$ takes values from -10 to +10 , indicating the number of quarters around elections. Sample includes all provinces. Each plotted coefficient comes from a single regression; bars around estimates show $90 \%$ confidence intervals. Each regression controls for province and time fixed effects. Estimates are reported separately for aligned and non-aligned provinces in each panel. 
Figure B.14: Tactical redistribution of state-bank credit over the election cycle: Dropping metropolitan cities that changed hands
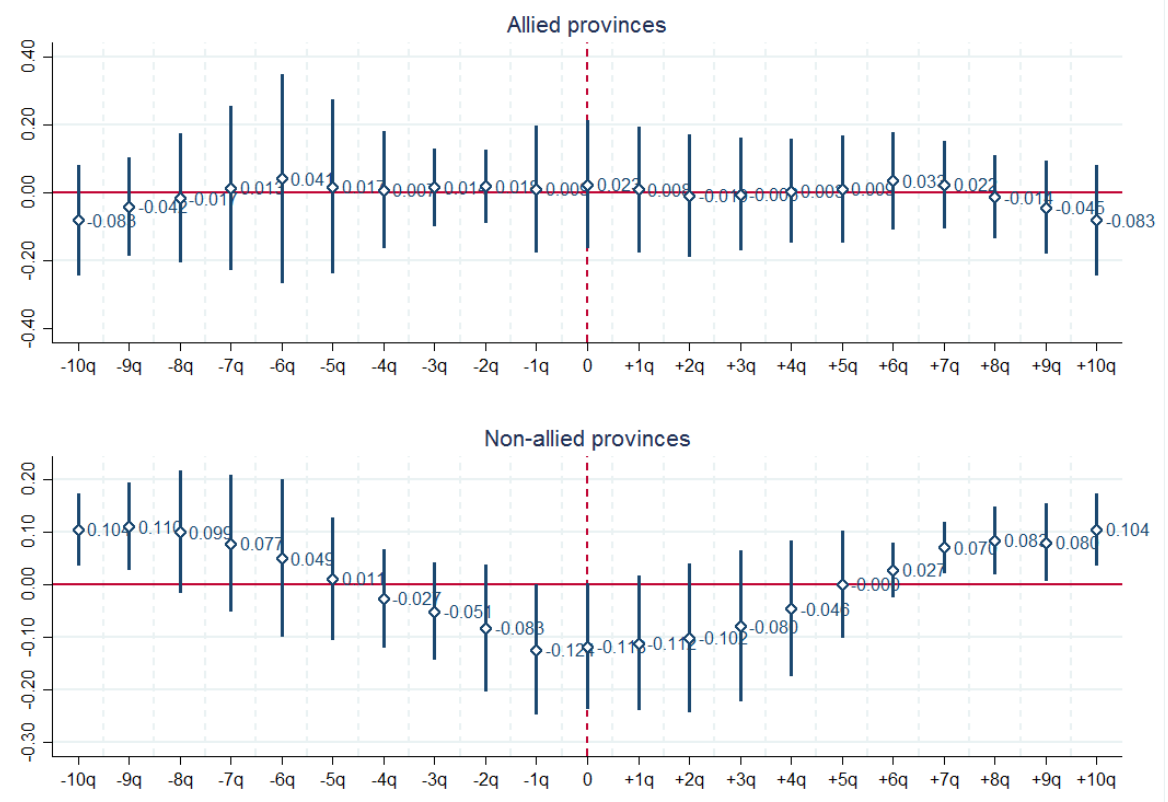

(a) Sample: Quarterly data, 2007q4-2017q4
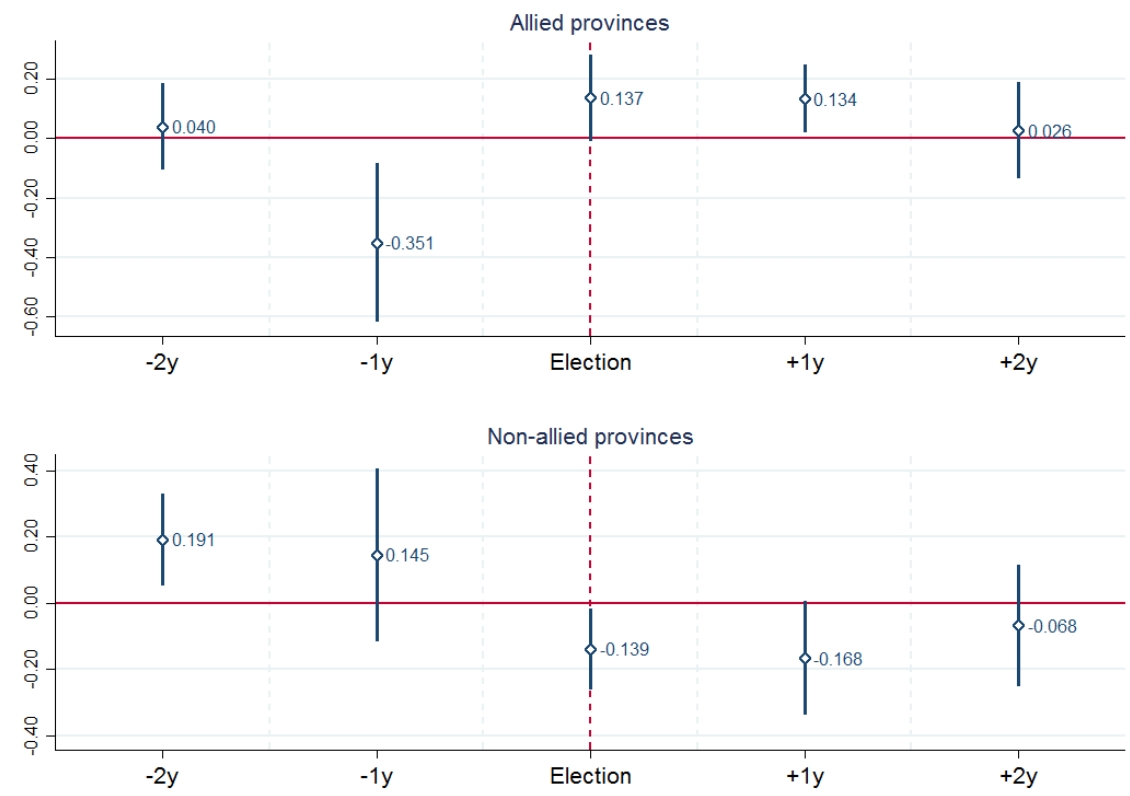

(a) Sample: Yearly data, 2003-2017

Notes: This figure shows results of equation (2) estimated on quarterly data (2007q4-2017q4) when $\tau$ takes values from -10 to +10 in panel A, and on yearly data (2003-2017) when $\tau$ takes values from -2 to +2 in panel B. Sample includes metropolitan provinces. The estimation sample excludes provinces that changed hands from one political party to another during the sample period. Each plotted coefficient comes from a single regression; bars around estimates show $90 \%$ confidence intervals. Each regression controls for local branches, our baseline set of fixed effects, and province time trends. Estimates are reported separately for aligned and non-aligned provinces in each panel. 


\section{Appendix C}

Figure C.1: Effects of political lending on short-term and long-term corporate borrowing in manufacturing
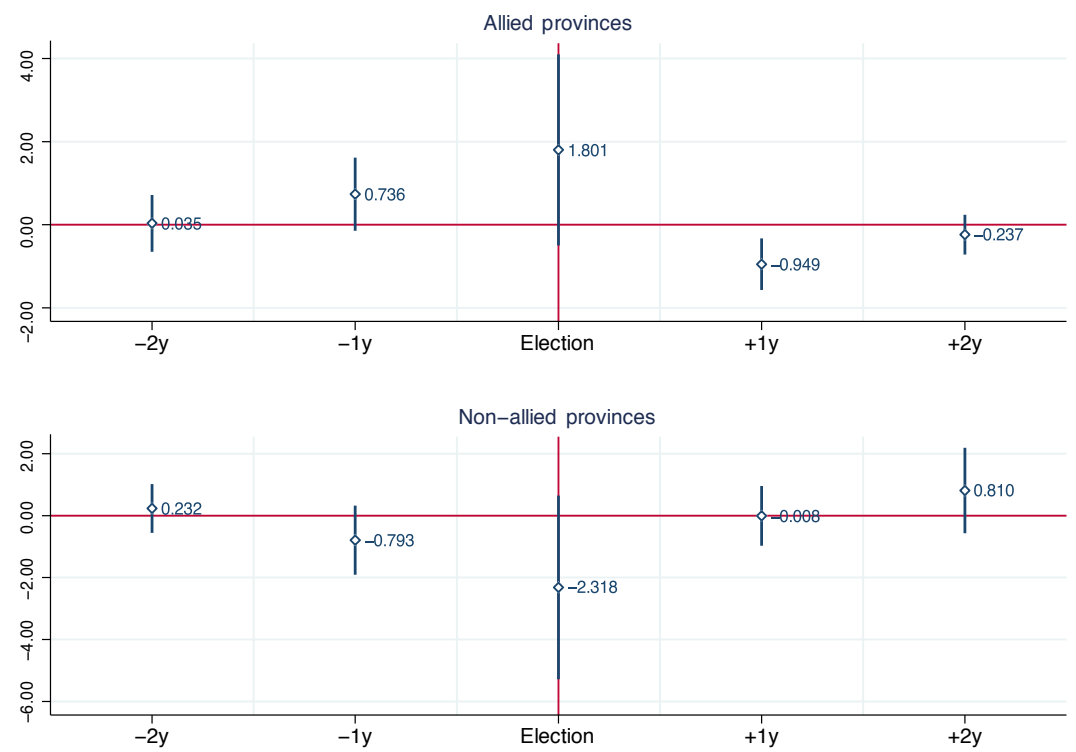

(a) Dependent variable: Short-term bank debt
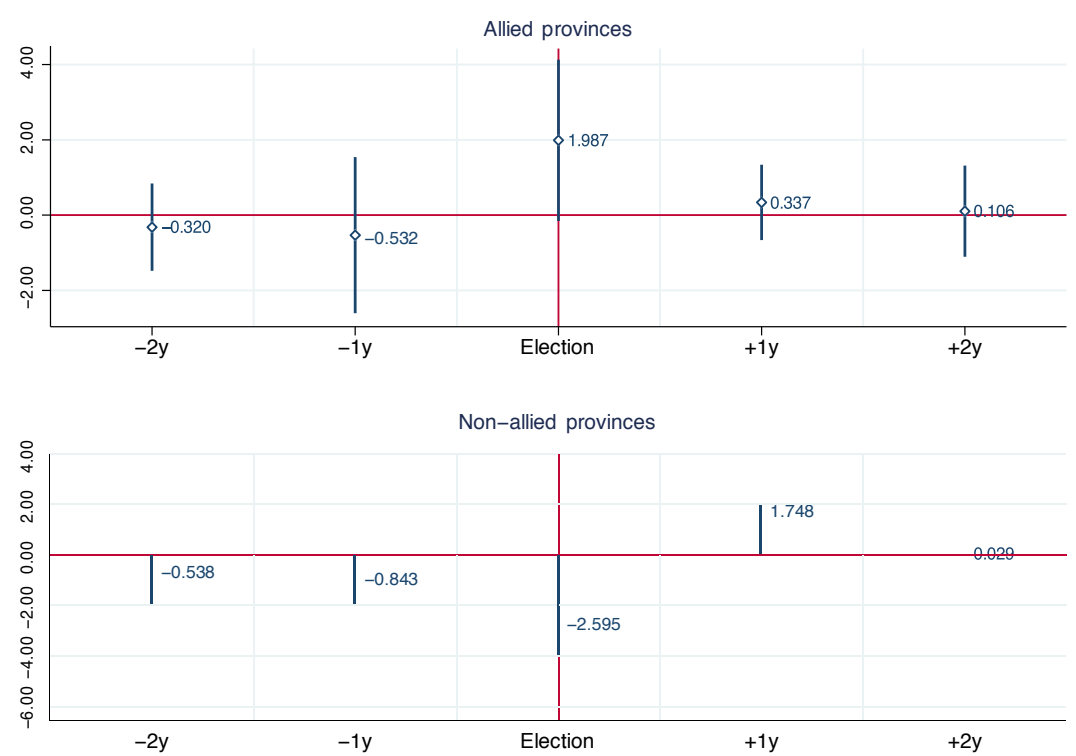

(b) Dependent variable: Long-term bank debt

Notes: This figure shows results of equation (6) estimated on yearly data (2006-2016) when $\tau$ takes values from -2 to +2 , indicating the number of years around elections, for metropolitan provinces. Each plotted coefficient comes from a single regression; bars around estimates show $90 \%$ confidence intervals. Each regression controls for a set of fixed effects and province time trends. Panel A shows estimates for total corporate bank debt and panel B shows estimates for total corporate long-term bank debt. Estimates are reported separately for aligned and non-aligned provinces in each panel. 
Figure C.2: Effects of political lending on corporate activity in all sectors
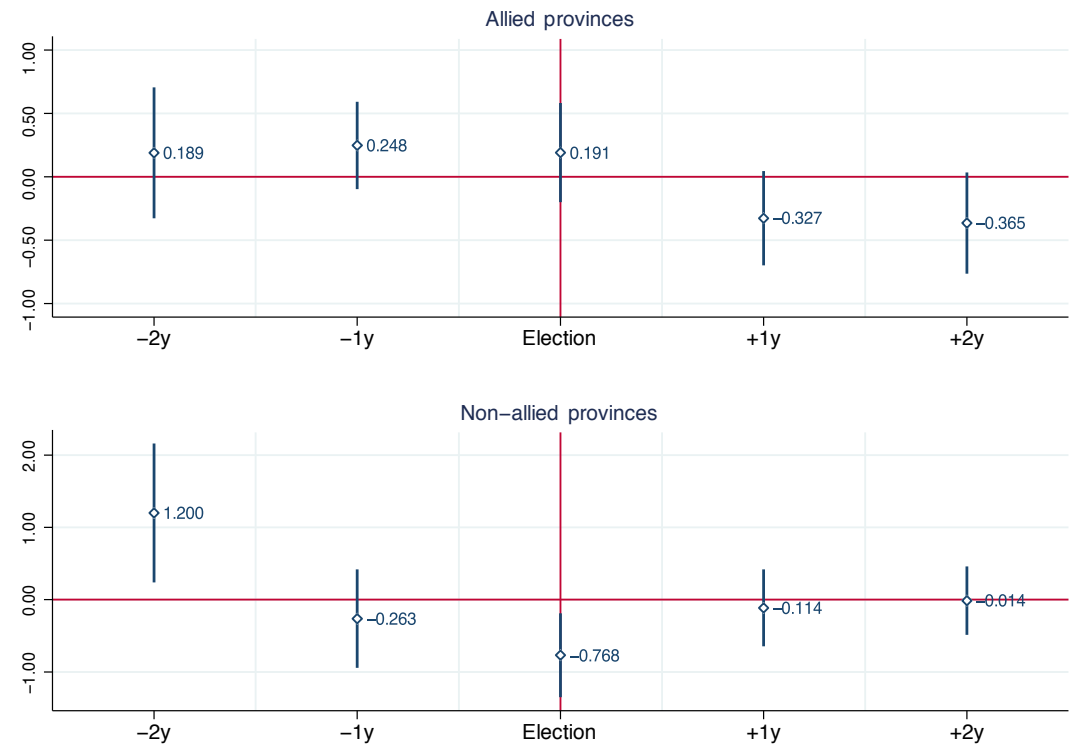

(a) Dependent variable: Employment
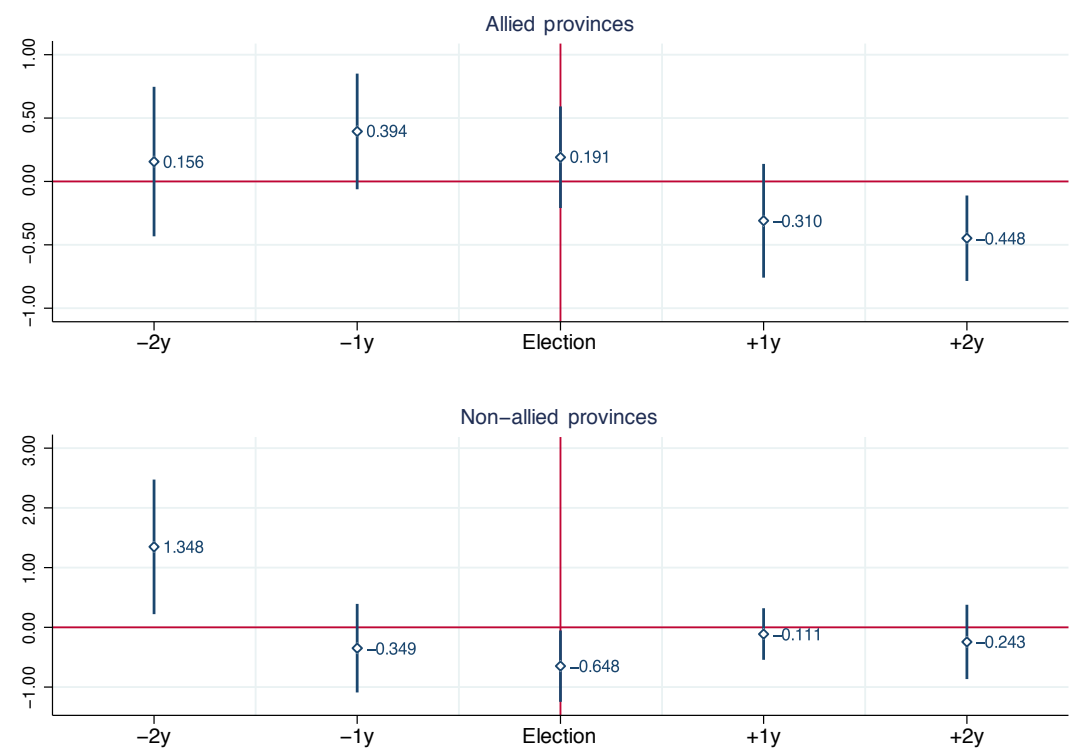

(b) Dependent variable: Net sales

Notes: This figure shows results of equation (6) estimated on yearly data (2006-2015) when $\tau$ takes values from -2 to +2 , indicating the number of years around elections, in metropolitan provinces and including all sectors of the economy. Each plotted coefficient comes from a single regression; bars around estimates show $90 \%$ confidence intervals. Each regression controls for a set of fixed effects and province time trends. Panel A shows estimates for employment and panel B shows estimates for net sales. Estimates are reported separately for aligned and non-aligned provinces in each panel. 
Figure C.3: Effects of political lending on corporate activity in manufacturing across all provinces
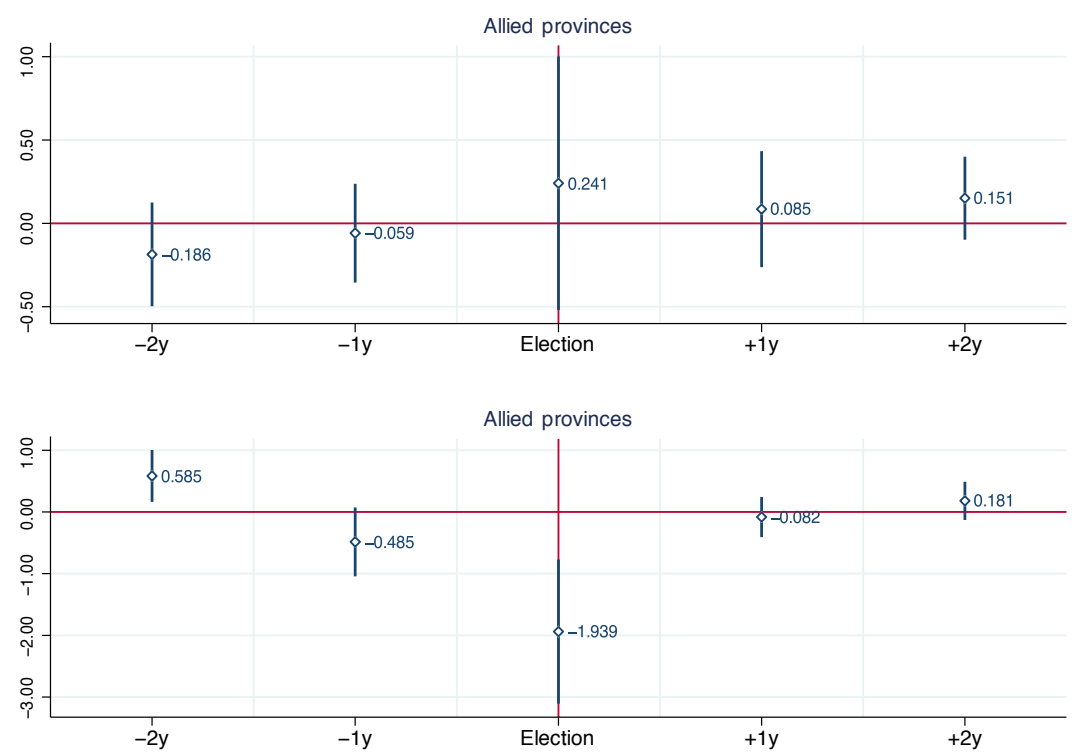

(a) Dependent variable: Employment
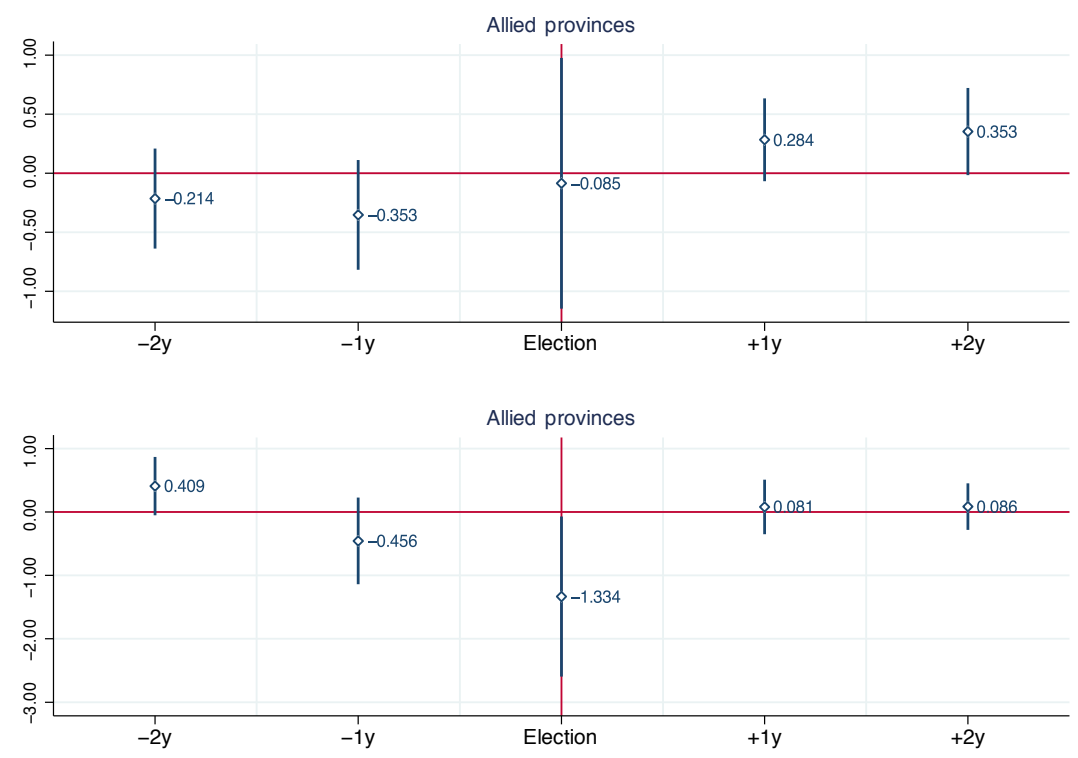

(b) Dependent variable: Net sales

Notes: This figure shows results of equation (6) estimated on yearly data (2006-2016) when $\tau$ takes values from -2 to +2 , indicating the number of years around elections, for all provinces. Each plotted coefficient comes from a single regression; bars around estimates show $90 \%$ confidence intervals. Each regression controls for a set of fixed effects and province time trends. Panel A shows estimates for employment and panel B shows estimates for net sales. Estimates are reported separately for aligned and non-aligned provinces in each panel. 
Figure C.4: Effects of political lending on corporate activity in manufacturing industries
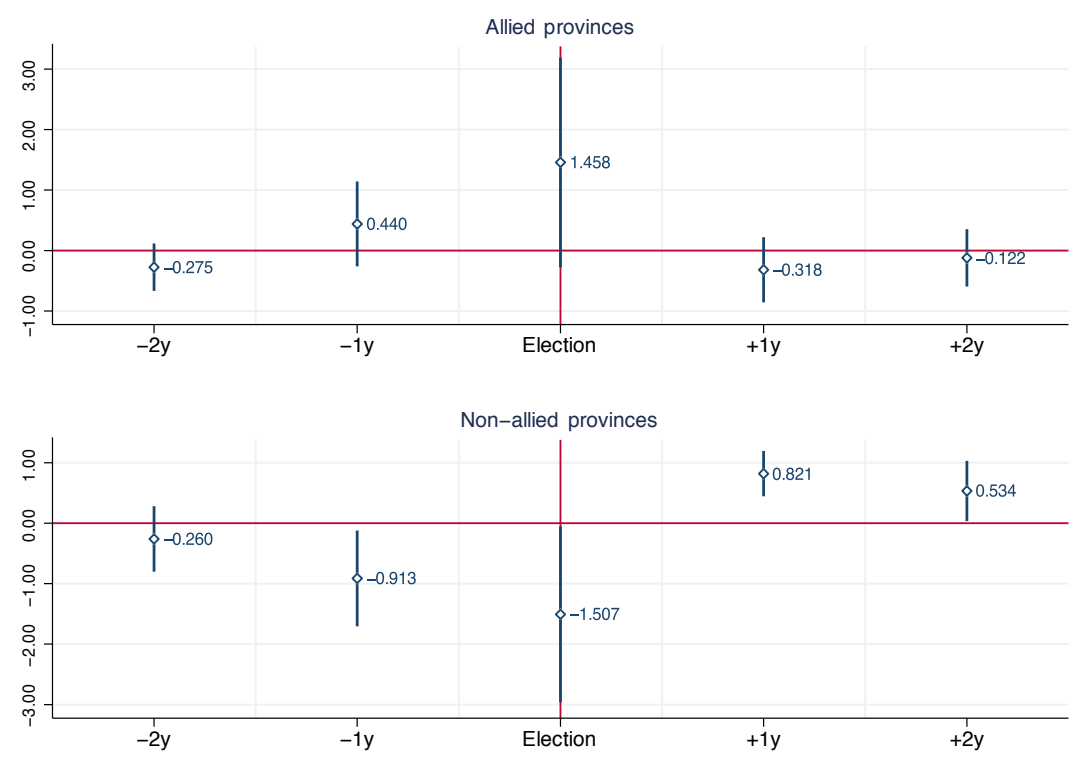

(a) Dependent variable: Total Assets
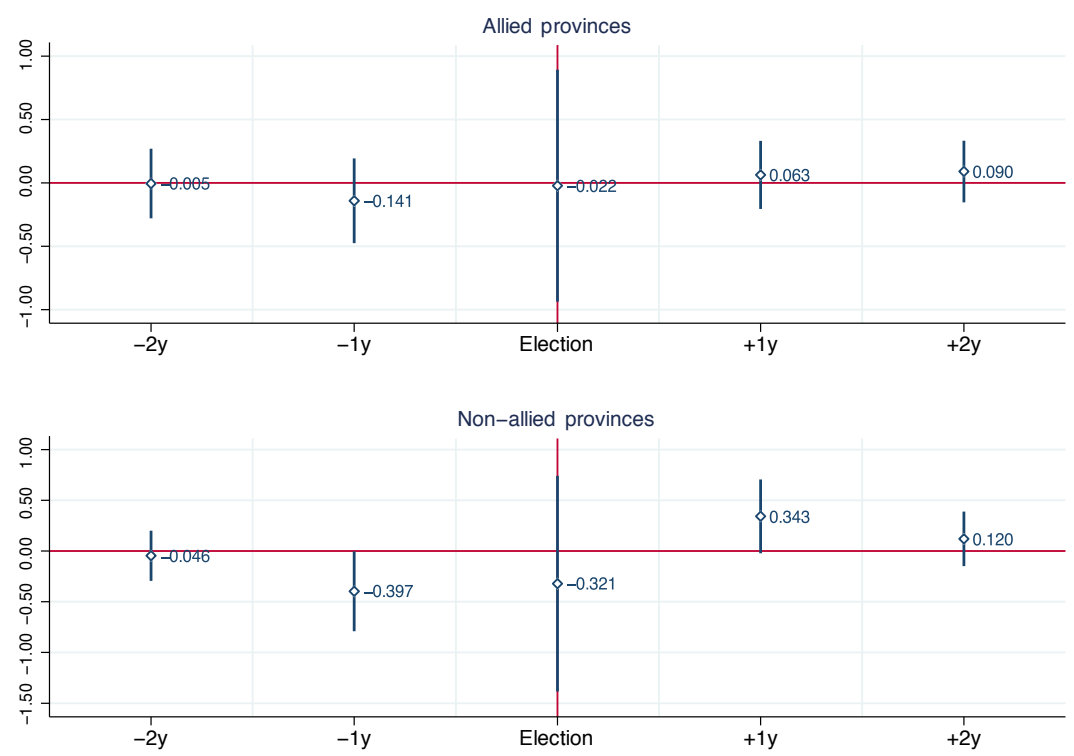

(b) Dependent variable: Number of Enterprises

Notes: This figure shows results of equation (6) estimated on yearly data (2006-2016) when $\tau$ takes values from -2 to +2 , indicating the number of years around elections, for metropolitan provinces. Each plotted coefficient comes from a single regression; bars around estimates show $90 \%$ confidence intervals. Each regression controls for a set of fixed effects and province time trends. Panel A shows estimates for total assets and panel B shows estimates for number of enterprises in operation. Estimates are reported separately for aligned and non-aligned provinces in each panel. 


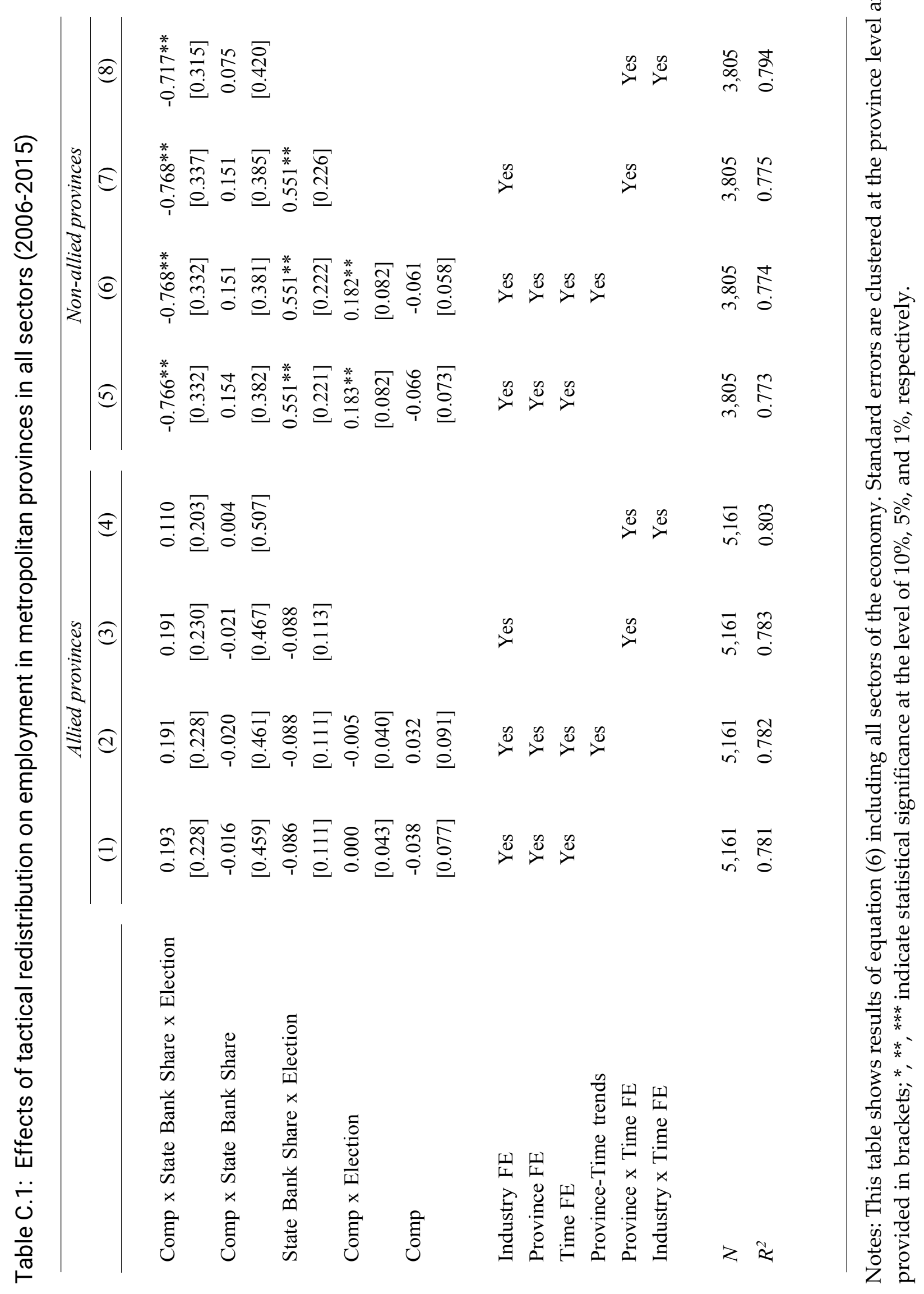




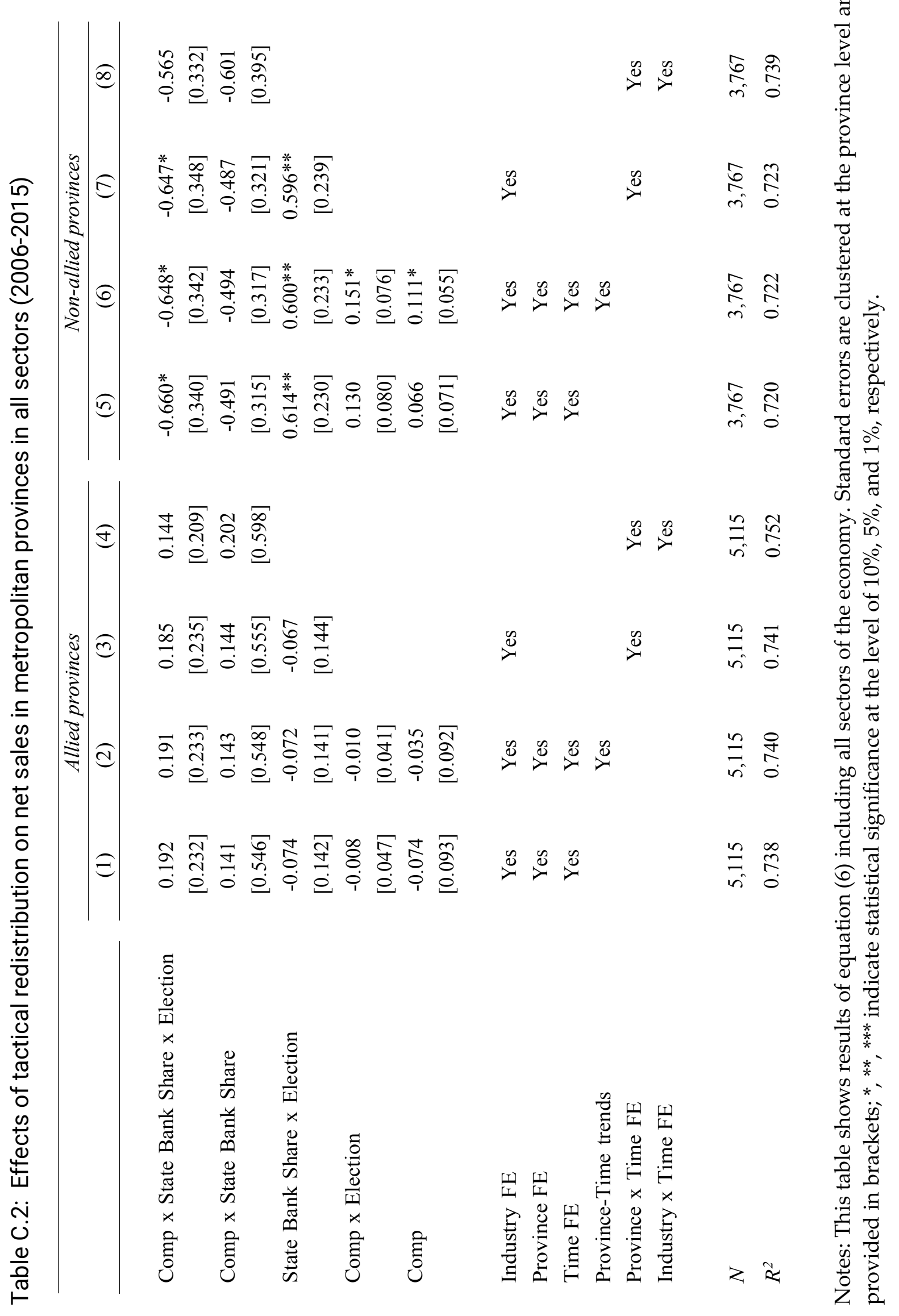




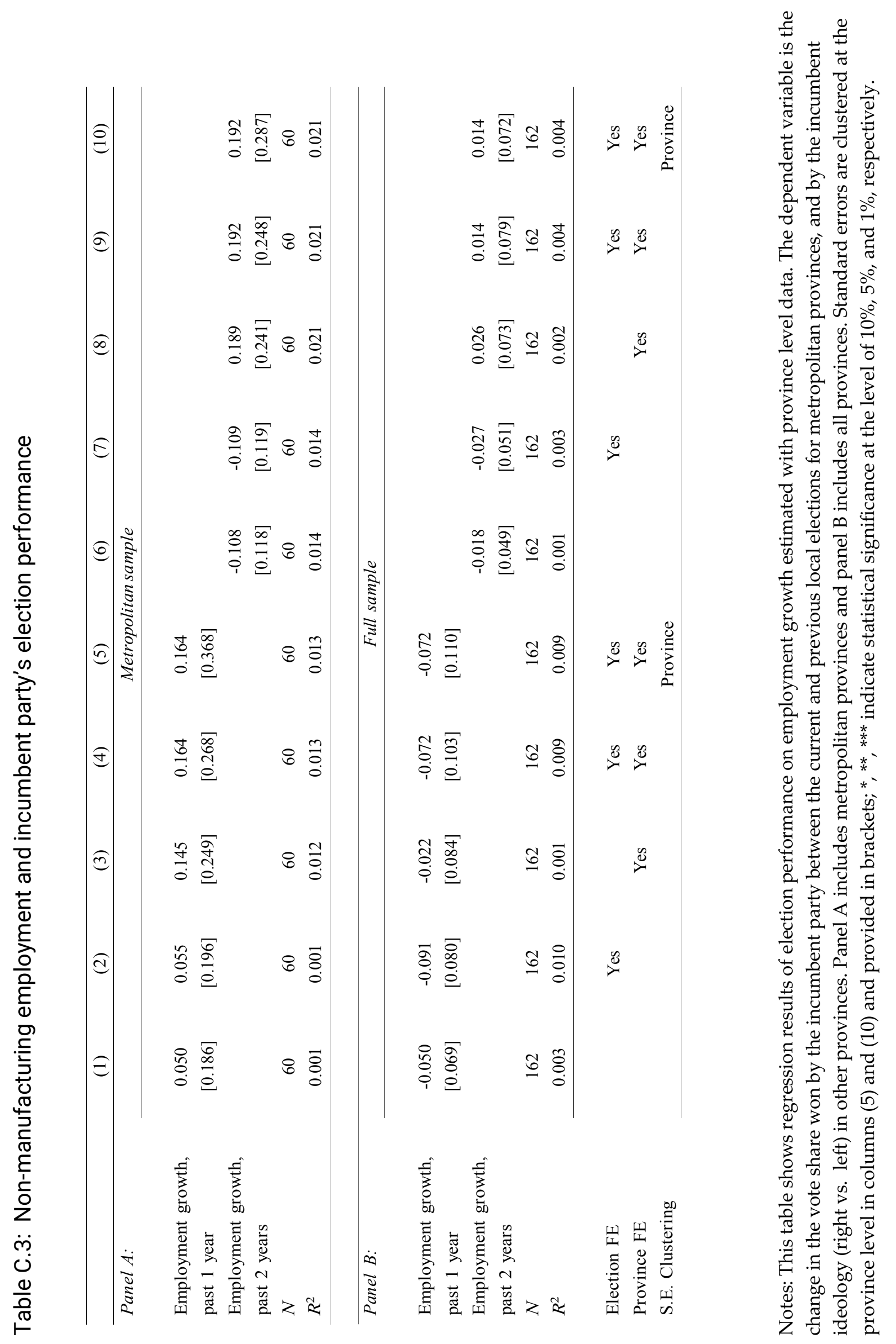




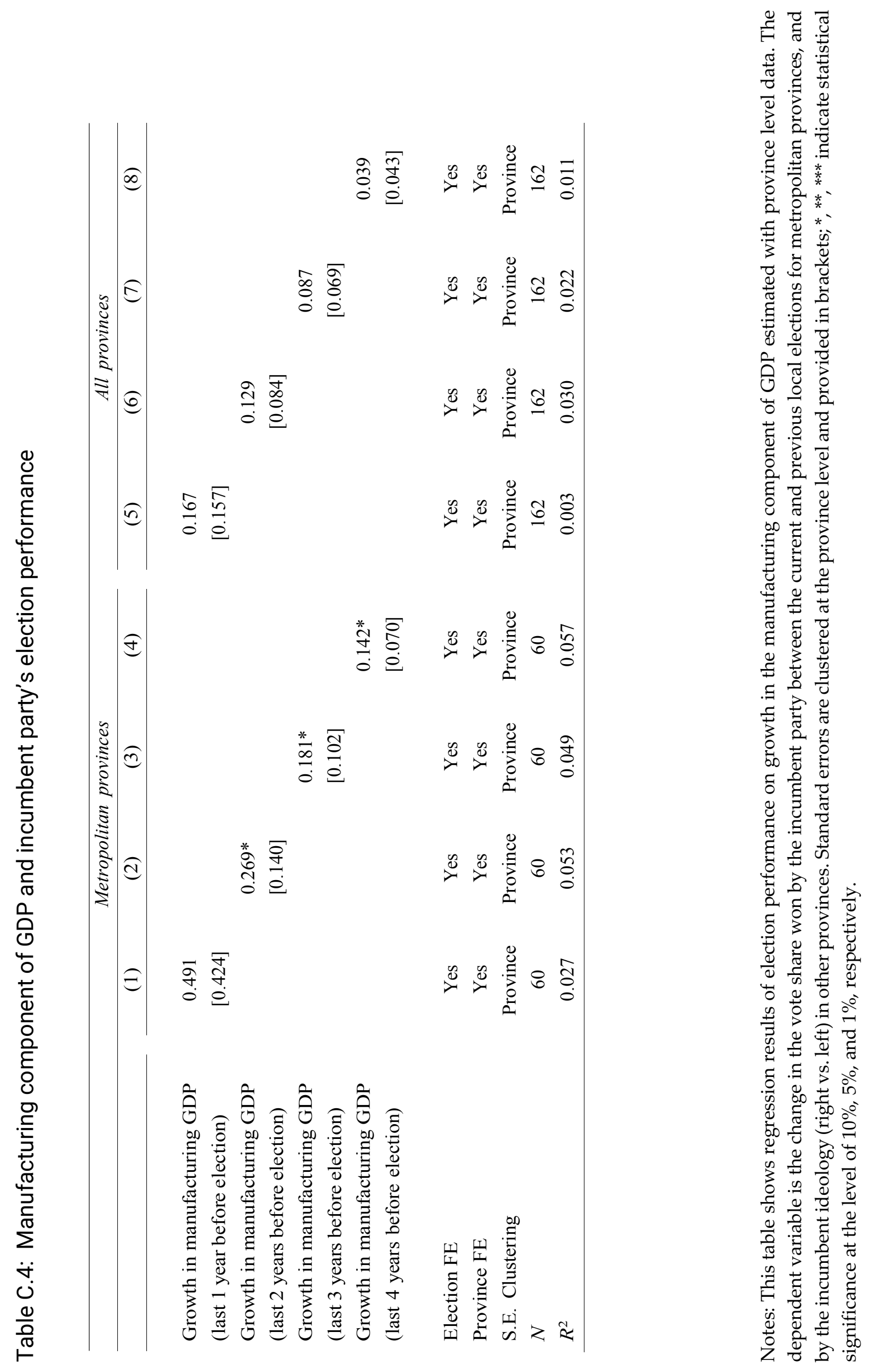




\section{Recent LEQS papers}

Wolkenstein, Fabio. 'Transnational Partisanship and Networked Constituent Power in the EU' LEQS Paper No. 138 , October 2018

Macchiarelli, Corrado 'What is the EU-UK relation all about? Tracking the path from monetary integration to "ever closeness"' LEQS Paper No. 137, September 2018

Meyer, Niclas 'EU break-up? Mapping plausible pathways into alternative futures' LEQS Paper No. 136, August 2018

Di Cataldo, Marco \& Monastiriotis, Vassilis 'An assessment of EU Cohesion Policy in the UK regions: direct effects and the dividend of targeting' LEQS Paper No. 135, June 2018

Innes, Abby 'First-best-world economic theory and the second-best-world of public sector outsourcing: the reinvention of the Soviet Kombinat by other means' LEQS Paper No. 134, May 2018

Bojar, Abel 'With a Little Help from My Friends: Ministerial Alignment and Public Spending Composition in Parliamentary Democracies' LEQS Paper No. 133, April 2018

Voss, Dustin “The Political Economy of European Populism: Labour Market Dualisation and Protest Voting in Germany and Spain" LEQS Paper No. 132, March 2018

Campos, Nauro F. \& Macchiarelli, Corrado “Symmetry and Convergence in Monetary Unions” LEQS Paper No. 131, March 2018

Costa Font, Joan \& Perdikis, Laurie 'Varieties of Health Care Devolution: "Systems or Federacies"?' LEQS Paper No. 130, February 2018

Calrsson, Ulrika “The Perennial Thirty Years' War” LEQS Paper No. 129, February 2018

Isiksel, Turkuler "Square peg, round hole: Why the EU can't fix identity politics" LEQS Paper No. 128, January 2018

Hancké, Robert \& Vlandas, Tim “The Politics of Disinflation” LEQS Paper No. 127, December 2017

White, Jonathan "Between Rules and Discretion: Thoughts on Ordo-liberalism" LEQS Paper No. 126, November 2017

Costa Font, Joan \& Zigante, Valentina “Building 'Implicit Partnerships'? Financial Long Term Care Entitlements in Europe" LEQS Paper No. 125, October 2017

Bohle, Dorothee “Mortgaging Europe's periphery" LEQS Paper No. 124, September 2017

Iordanoglou, Chrysafis \& Matsaganis, Manos "Why Grexit cannot save Greece (but staying in the Euro area might)" LEQS Paper No. 123, August 2017

Saka, Orkun "'Domestic banks as lightning rods? Home bias during the Eurozone crisis" LEQS Paper No. 122, February 2017

Coulter, Steve “Signalling Moderation: UK Trade Unions, 'New Labour' and the Single Currency” LEQS Paper No. 121, December 2016

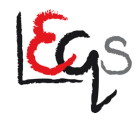




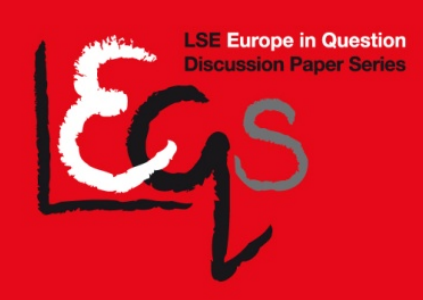

\section{LEQS}

European Institute London School of Economics Houghton Street WC2A 2AE London Email: euroinst.LEQS@Ise.ac.uk

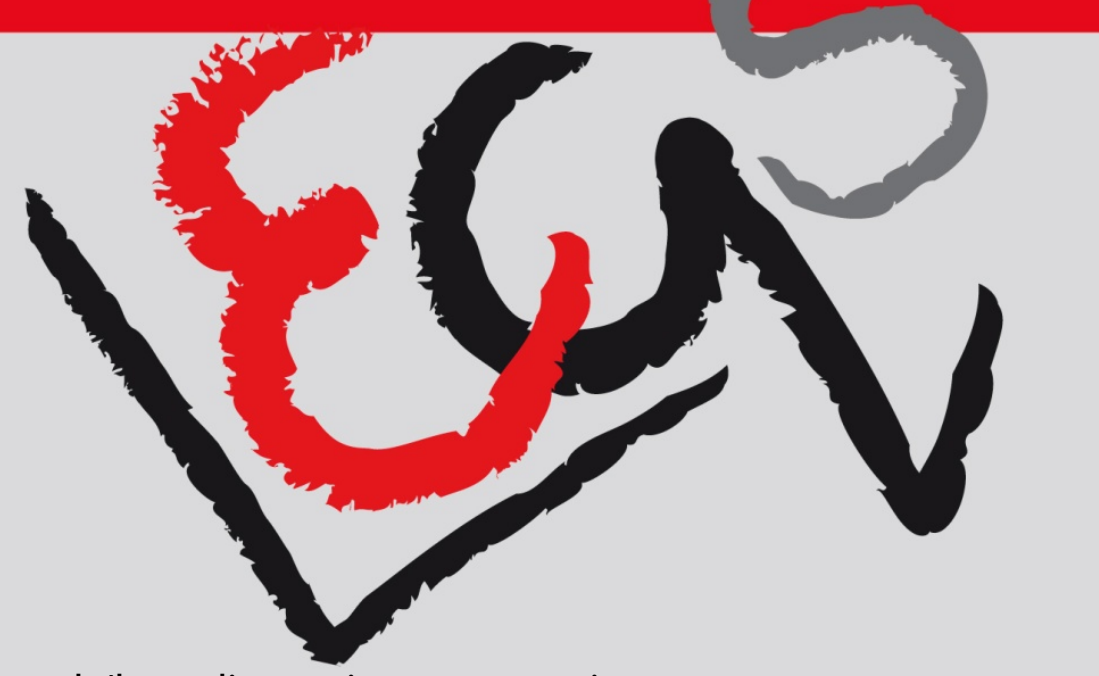

http://www.Ise.ac.uk/european-institute/research/leqs-discussion-paper-series 